\title{
Systematics of Lutetian larger foraminifera and magneto- biostratigraphy from the South Pyrenean Basin (Sierras Exteriores, Spain)
}

\author{
Roi Silva-Casal ${ }^{1} \quad$ Josep Serra-Kiel $^{2} \quad$ Adriana Rodríguez-Pintó $^{3} \quad$ Emilio L. Pueyo $^{4,5} \quad$ Marc Aurell $^{6}$ Aitor Payros $^{7}$
}

1'Institut de Recerca Geomodels, Departament de Dinàmica de la Terra i de l'Oceà, Universitat de Barcelona Martí i Franquès s/n, 08028 Barcelona, Spain. Silva-Casal E-mail: roi.silva.casal@gmail.com

${ }^{2}$ Museu de Ciències Naturals de Barcelona, Departament de Paleontologia Passeig Picasso s/n, 08003 Barcelona, Spain (Deceased)

${ }^{3}$ Freelance Geologist consultor

Rodríguez-Pintó E-mail: adrianaropi14@gmail.com

${ }^{4}$ Instituto Geológico y Minero de España, Unidad de Zaragoza

Manuel Lasala 44, 50009 Zaragoza, Spain. Pueyo E-mail: unaim@igme.es

${ }^{5}$ Associated Unit in Earth Sciences IGME/Universidad de Zaragoza

Spain. Pueyo E-mail: unaim@igme.es

${ }^{6}$ Department of Earth Science, University of Zaragoza

Pedro Cerbuna 12, E50009 Zaragoza, Spain. Aruell E-mail: maurell@unizar.es

7Department of Stratigraphy and Paleontology, Faculty of Science and Technology, University of the Basque Country (UPV/EHU) PO Box 644, E48080 Bilbao, Spain. Payros E-mail: a.payros@ehu.eus

A systematic description of the Eocene larger foraminifera recorded in the South Pyrenean Basin (Sierras Exteriores) is presented herein. The large dataset provided in this work includes Nummulites and Alveolina species, along with a variety of other porcellaneous and hyaline taxa with lesser biostratigraphic relevance. Most of the larger foraminifera described in this work correspond to the Lutetian (SBZ13 to SBZ16 biozones) interval, but late Ypresian (SBZ11, Cuisian) and early Bartonian (SBZ17) shallow benthic zones have also been identified. A new species, Idalina osquetaensis, is described. The systematic revision of middle to late Lutetian alveolines led to a reassessment of Alveolina fusiformis and the finding of two new precursor forms, described as Alveolina aff. fragilis and Alveolina aff. elongata. The new taxa fill in the gap existing so far in the middle to late Lutetian alveolinid biostratigraphy. Despite not being exclusive to SBZ16, these forms provide realiable biostratigraphic information in facies where Nummulites are not present. This realibility lies on the correlation of Nummulites and Alveolina biostratigraphic markers in the same sections and their calibration to the global time scale through magnetostratigraphy. 
Magnetostratigraphic calibration of described taxa is provided, along with an update of the SBZ calibration to the Geological Time Scale (Gradstein et al., 2012).

KEYWORDS $\quad$ SBZ recalibration; middle Eocene; southern Pyrenees; Paleogene biostratigraphy.

\section{INTRODUCTION}

Larger foraminifera are a widely distributed polyphyletic group of marine benthic organisms. These taxa are the result of a stepwise evolutionary trend towards highly adapted k-strategist organisms in stable ecological conditions (Hallock, 1985). Indeed, the variety of morphological adaptations in the shallow marine symbiont-bearing larger foraminifera is related to the specific energy levels, water depths and substrate types of the carbonate shelves where they throve (Hottinger, 1983). The facies specificity of larger foraminifera determines their usefulness in facies analysis and palaeoenvironmental reconstructions. However, this may be disadvantageous for biostratigraphic purposes.

The facies dependence of single taxa is avoided in larger foraminifera biostratigraphy (Shallow Benthic Zones (SBZ), Serra-Kiel et al., 1998) through the usage of Oppelzones, characterized by an assemblage of selected taxa. The lower parts of these zones are largely marked by the first appearances of certain taxa, whereas their upper parts are marked by last appearances (Pignatti and Papazzoni, 2017). The quality of SBZs, thus, relies on the accuracy of correlations from stratigraphic sections where different sedimentary environments are represented. As pointed out by Serra-Kiel in Mochales et al. (2012), Costa et al. (2013) and Rodríguez-Pintó et al. (2012a, b), magnetostratigraphy has extensively been used for this purpose, also providing chronostratigraphic calibration to the SBZs. At a regional scale, the lithostratigraphic correlation of distinct sections, located in different positions of the carbonate shelf, can also improve the reliability of the biostratigraphic dataset.

The study of larger foraminifera biostratigraphy in the Pyrenean area has been of great importance for the definition of SBZ biozones (Canudo et al., 1988; Hottinger, 1960; Samsó et al., 1994; Schaub, 1981; Serra-Kiel, 1984; Tosquella, 1995). The Lutetian biozones (SBZ13 to SBZ16) of Serra-Kiel et al. (1998) are mostly based on data from this area. The magnetostratigraphic recalibration of this Lutetian biozones by Rodríguez-Pintó et al. (2012a) was also performed in the South-Pyrenean area (Guara Formation), focusing on Isuela and Gabardiella sections. However, the available data obtained by previous authors from the Guara Formation (Fm.) (Canudo et al., 1988; Rodríguez-Pintó et al., 2012a; Samsó et al., 1994) shows the need for further studies of its larger foraminiferal content. Recently, Silva-
Casal (2017) and Silva-Casal et al. (2019) studied the lithostratigraphy, biostratigraphy and magnetostratigraphy of the Eocene shallow marine limestone units (Boltaña, Guara and Arguis formations) of the westernmost sector of the Sierras Exteriores in the Southern Pyrenees (west of Isuela section), and a correlation with the outcrops of the Sierra de Guara further to the east was proposed. Based on these earlier studies, the work presented herein comprises an extensive biostratigraphic dataset obtained from 11 sections of the Sierras Exteriores (Fig. 1), which were correlated by lithostratigraphic and magnetostratigraphic means. Thus, we provide a magnetostragraphically correlated and calibrated regional study of the Lutetian biozones (SBZ13SBZ16) of the Guara Formation, including some data for the Bartonian Arguis Fm. (SBZ 17) and the upper Ypresian Boltaña Fm. (SBZ 11).

\section{GEOLOGICAL AND STRATIGRAPHIC SETTING}

The Pyrenean chain is a double vergence orogen formed by the antiformal stacking of basement thrust sheets during the Santonian to Miocene N-S convergence of the Iberian and European plates (Muñoz, 1992). In middle Eocene times, this orogen developed foreland basins on both North-Pyrenean and South-Pyrenean sides, with a turbiditic succession deposited in the proximal foredeep, flanked by a shallow marine carbonate ramp in the more distal margin of the South Pyrenean Basin (Garcés et al., 2020; Plaziat, 1981).

The Sierras Exteriores are located in the South Pyrenean western zone (Jaca-Pamplona basin) and include syntectonic materials involved in the Pyrenean orogeny (Barnolas and Pujalte, 2004). They represent the emergence of the South Pyrenean sole thrust in the southwestern part of the chain. Variable along-strike shortening estimates of this basal thrust range between 35 to $10 \mathrm{~km}$ (Millán et al., 1996) allowing for the exposure of Lutetian platform rocks in the hangingwall block that rides over the $4000 \mathrm{~m}$ thick Oligocene molasse of the Ebro foreland basin (Oliva-Urcia et al., 2019). The middle Eocene limestones exposed in the Sierras Exteriores were deposited in the distal, shallow marine margin of the South Pyrenean foreland basin (Fig. 1).

The stratigraphic record of the Sierras Exteriores is represented by Triassic to Neogene materials 
(Puigdefàbregas and Souquet, 1986). Overlying a very condensed and incomplete Mesozoic succession, the Upper Cretaceous-Paleogene transition is represented by continental deposits, which are part of the Tremp Fm. (Mey et al., 1968). The Eocene limestone succession has been divided into the following lithostratigraphic formations:

The Boltaña Formation (Barnolas et al., 1991), lying unconformably on top of the Tremp Formation, represents the beginning of the shallow marine carbonate sedimentation associated with the evolution of the foreland basin. In the study area this unit only occurs in the Gabardiella section (eastern part of the study area). There, the Boltaña Formation is characterized by a $30 \mathrm{~m}$ thick alternation of limestones and marls. The limestones contain abundant porcellaneous foraminifera (Alveolina, Idalina) and conical agglutinated forms (Coskinolina). In the study area, this unit has been attributed to the late Ypresian (Cuisian) SBZ11 (Rodríguez-Pintó et al., 2012a) and correlated to magnetic polarity Chron C22r (Rodríguez-
Pintó et al., 2017). The thicker Ara River section in the east, at the core of the Boltaña anticline spans from the upper part of chron C24n to chron C22r (Mochales et al., 2012).

The Guara Fm. (Puigdefàbregas, 1975) characterizes the Lutetian succession of the Sierras Exteriores. It consists of shallow marine carbonates lying unconformably on the top of the Boltaña Fm. in the Gabardiella section and on the top of the Tremp Fm. further to the west. The lowermost deposits of the Guara Fm. are also highly diachronous, becoming younger westwards. The Guara Fm. spans from chron C22n to C18r, from SBZ 11 (middle Cuisian) to SBZ 16 (late Lutetian) (Rodríguez-Pintó et al., 2012a, 2013a; Silva-Casal, 2017; Silva-Casal et al., 2019).

The Guara Fm. was divided into three non-formal lithostratigraphic units, Lower, Middle and Upper Guara units (Rodríguez-Pintó et al., 2012a; Samsó et al., 1992, 1994). In this work we regard these units as members of the Guara Fm. (see also Silva-Casal et al., 2019). The Isuela
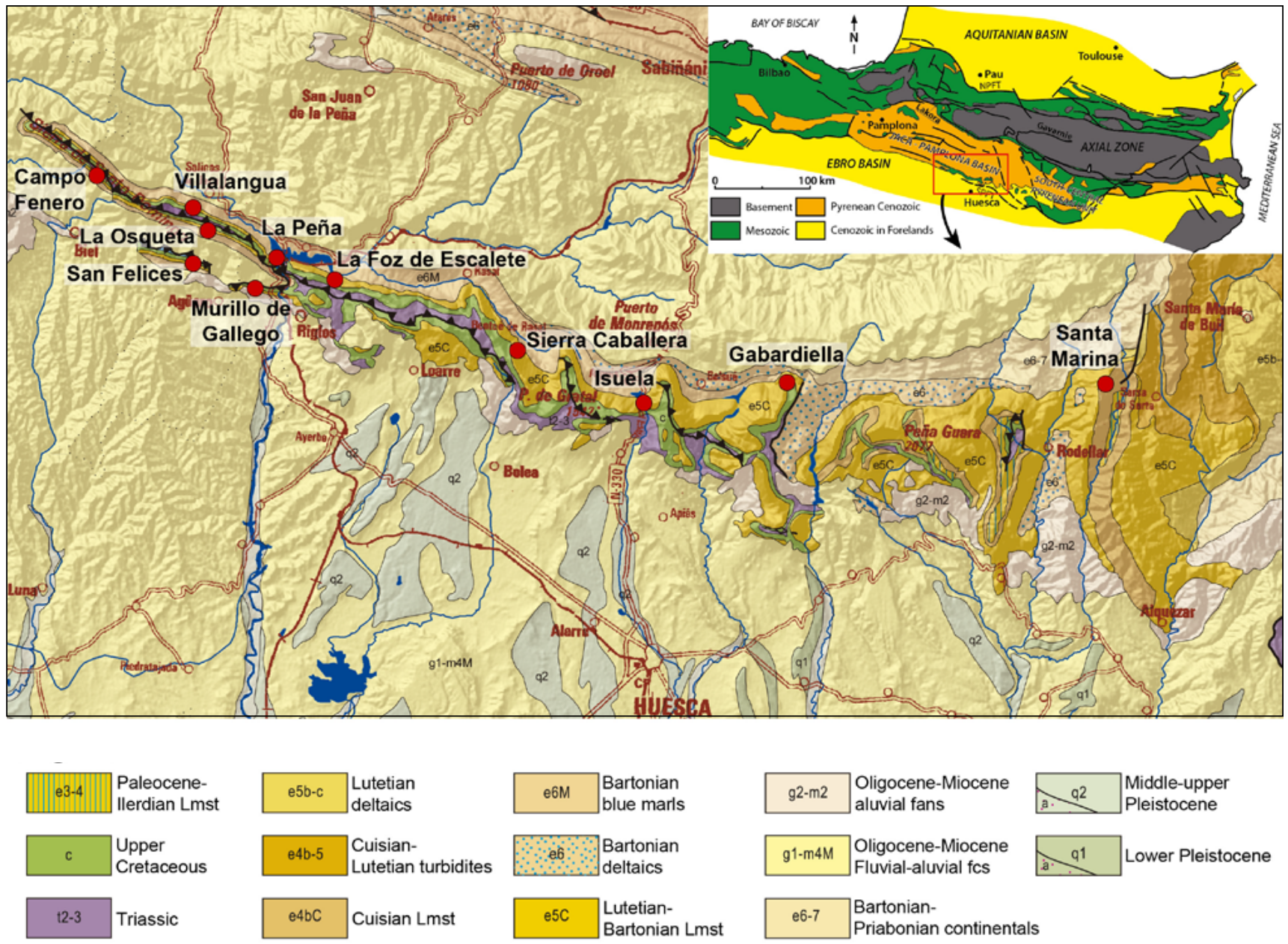

FIGURE 1. Simplified geological map of the study area in the Pyrenean Sierras Exteriores, with location of the sections described in the text. 
section is considered the reference section of the Guara Fm. and of all its members:

- Lower Guara Mb. This unit has been recognized in the Santa Marina (Fig. 2), Gabardiella (Fig. 3), Isuela (Fig. 4) and Sierra Caballera sections (Fig. 5). The thickness of this unit ranges from $200 \mathrm{~m}$ in the eastern part of the study area (Gabardiella section) to $100 \mathrm{~m}$ in the Sierra Caballera section, its westernmost outcrop. In the Isuela reference section, the Lower Guara Mb. consists of an alternation of bioclastic limestones (mainly composed of porcellaneous larger foraminifera) and marls, with some characteristic levels of conglomerates. This unit was deposited in transitional to shallow marine subtidal environments (Rodríguez-Pintó et al., 2012a; Samsó et al., 1992; SilvaCasal, 2017).

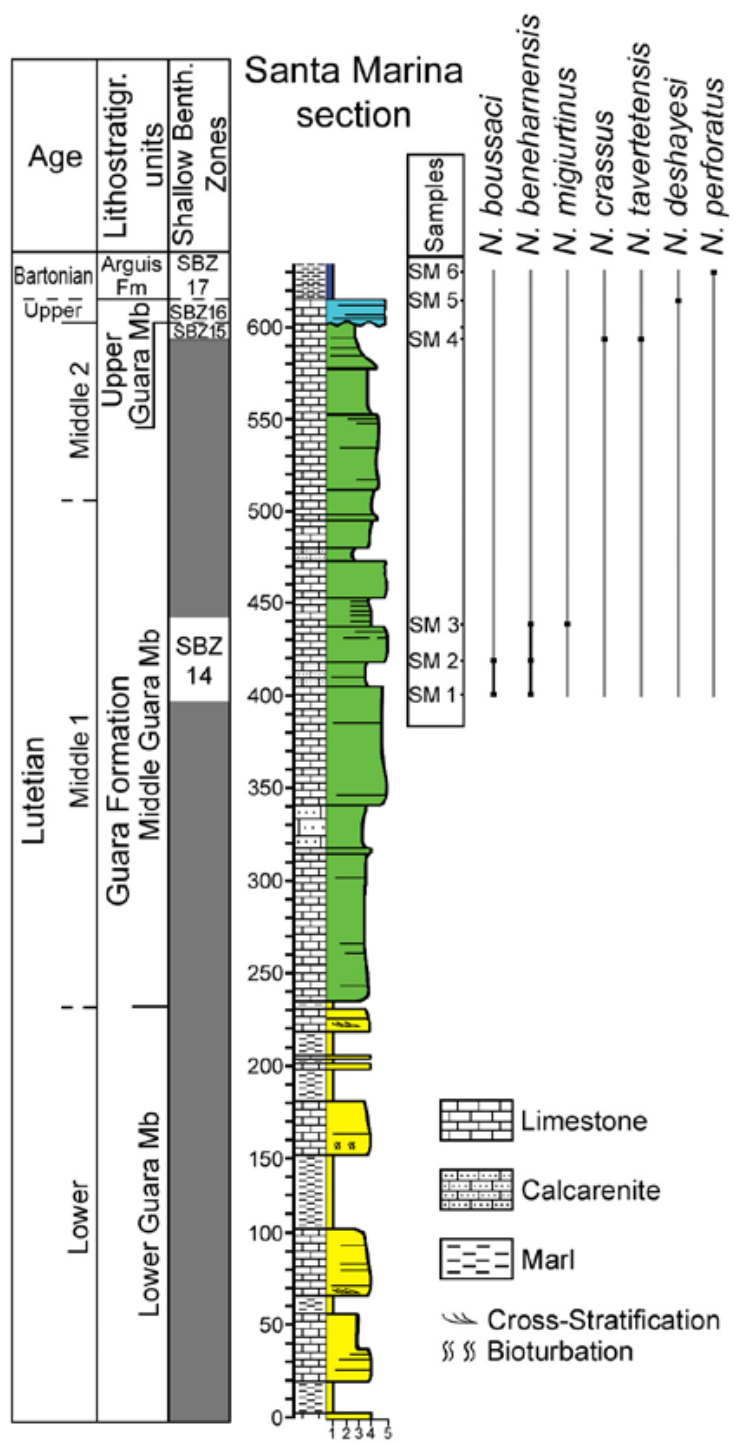

FIGURE 2. Stratigraphic succession (modified from Rodríguez-Pintó et al., 2012b) and distribution of larger foraminifera in the Santa Marina section.
- Middle Guara Mb.This unit crops out in the Santa Marina, Gabardiella, Isuela, Sierra Caballera, la Foz de Escalete, La Peña, Murillo de Gállego and Villalangua sections (Figs. 2-9). According to Samsó et al. (1992) and Rodríguez-Pintó et al. (2012a), the basal contact of this unit is transgressive. This member is mainly composed of porcellaneous foraminiferal facies, with abundant Alveolina and Orbitolites, and trematophore miliolids (Idalina, Pseudolacazina, among others), deposited in shallow subtidal environments (Silva-Casal, 2017, SilvaCasal et al., 2019). Cross stratification, including largescale cross- bedding, is common. Despite the overall facies homogeneity of this unit, it changes to the west to more restricted environments, with the occurrence of lagoonal marls and some siliciclastic levels, whereas to the east Nummulites-rich beds can be observed. This lateral change of facies from distal-to-proximal, i.e. east to west, could explain the reduction in thickness from $550 \mathrm{~m}$ in the Gabardiella section to only $20 \mathrm{~m}$ in the Villalangua section.

- Upper Guara Mb. This unit is present throughout the study area, with the only exception of the Campo Fenero section. The lower boundary of this unit is an erosive surface (Santa Marina section, Fig. 2), which grades to a correlative conformity. This unit is characterized by a facies association of acervulinid and porcellaneous foraminiferal facies and Nummulites-bank facies, which were deposited in inner ramp vegetated environments and middle ramp environments respectively (Silva-Casal, 2017, SilvaCasal et al., 2019). In general, this unit shows a greater abundance of Nummulites-bank facies in the eastern outcrops, and more restricted facies to the west where acervulinid and alveolinid-rich facies predominate. In the study area, the maximum thickness $(90 \mathrm{~m})$ is found between La Foz de Escalete section (Fig. 6) and the Isuela section (Fig. 4), and the minimum thickness (30m) in La Osqueta section (Silva-Casal et al., 2019). The top of the Guara Fm. has been interpreted as a drowning unconformity (Millán et al., 1994; Silva-Casal, 2017; Silva-Casal et al., 2019). Above this boundary, the Upper Guara Mb. is overlain by the Arguis Fm. (Puigdefàbregas, 1975).

The Arguis Fm. records a major change in the sedimentation in the Jaca-Pamplona basin. The dominant carbonate ramp sedimentation was replaced by a marly sedimentation, in a deeper, outer ramp environment with higher siliciclastic imput. The Arguis Fm. is mainly composed of blue marls interbedded with limestones and marly limestones (Millán et al., 1994; Morsilli et al., 2012). The classic Arguis section spans from chron C18r to C16r, just below the diachronic deltaic Belsué-Atarés Fm., as deduced by paleomagnetic studies (Hogan and Burbank, 1996; Kodama et al., 2010; Pueyo et al., 2002; RodríguezPintó et al., 2019). However, in the westernmost sector of the Sierras Exteriores, the marls of the lowermost part of the 


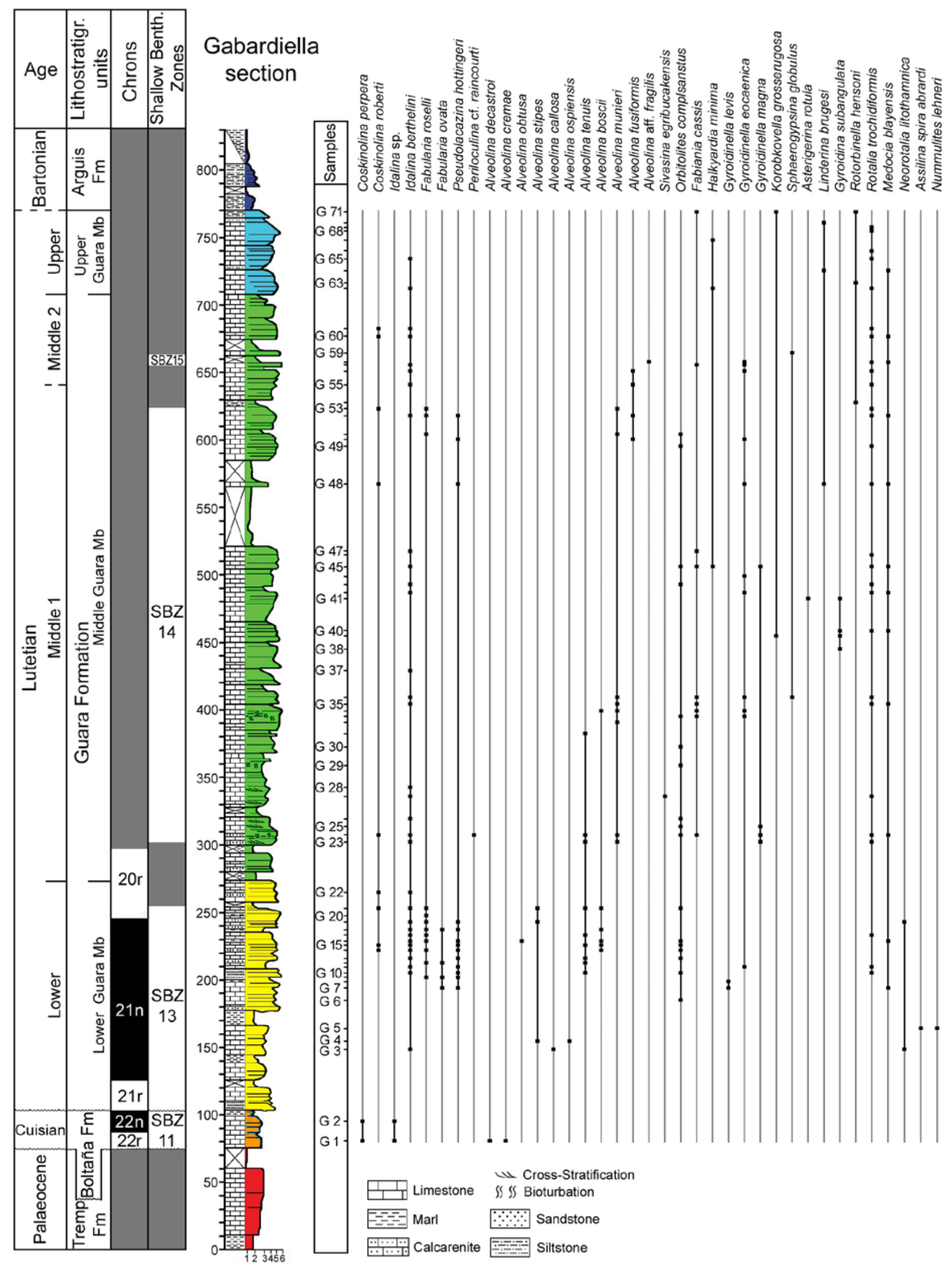

FIGURE 3. Stratigraphic succession and distribution of larger foraminifera in the Gabardiella section (modified from Rodríguez-Pintó et al., 2012a). Magnetostratigraphic data after Rodríguez-Pintó et al. (2017). 
Arguis Fm. grade laterally to a limestone dominated succession, included in the Santo Domingo Limestone Mb. (Silva-Casal, 2017).

- The Santo Domingo Mb. (Silva-Casal, 2017; SilvaCasal et al., 2019) was formally defined by its lithological differences with the underlying Guara Fm. and its lateral transition to the marls of the lower part of the Arguis Fm. The base of the Santo Domingo Mb. is defined by an erosive surface, related to the drowning unconformity that defines the top of the Upper Guara Mb.
In this study the Santo Domingo Mb. has been logged in the Murillo de Gállego, San Felices, La Osqueta, and Campo Fenero sections (Figs. 8; 10; 11; 12). This unit is characterized by a conspicuous glauconitic level at its base, which is considered a regional datum and allows lithostratigraphic correlation between sections (Silva-Casal, 2017, Silva-Casal et al., 2019). The Santo Domingo Mb. is also characterized by a shallow carbonate ramp facies association of outer and middle ramp facies with predominance of bryozoans, orthophragminids (Discocyclina, Asterocyclina) and red algae, and



FIGURE 4. Stratigraphic succession and distribution of larger foraminifera in the Isuela section (modified from Rodríguez-Pintó et al., 2012a). Magnetostratigraphic data after Rodríguez-Pintó et al. (2012a) and Rodríguez-Pintó et al. (2019). 
acervulinids and echinoids-rich inner ramp facies. Nummulites and Alveolina-rich facies are absent in this unit, but dispersed specimens of these species do occur.

\section{MATERIALS AND METHODS}

This work is based on 11 stratigraphic sections (Fig. 1) systematically and evenly sampled from the base to the top for biostratigraphic purposes. This sampling resulted in the description of 359 samples. The samples were studied in thin sections and polished slabs, except those collected to extract loose, separate specimens of nummulitids and alveolinids. These samples were disaggregated in a water, oxygen peroxide and $\mathrm{Na}_{2} \mathrm{CO}_{3}$ solution and then sieved through mesh apertures of $1.0,0.5$ and $0.2 \mathrm{~mm}$. The material studied is housed in three different repositories (Appendix I). The samples from the Isuela and Gabardiella sections (also named Arguis and Lúsera) are housed in the repository of the Instituto Geológico Minero de España (IGME). Some samples are included in the Serra-Kiel collection, provisionally housed in the Department of Earth and Ocean Dynamics, University of Barcelona (UB), and will be definitively deposited in the Museu de Ciències Naturals de Barcelona. Finally, the rest of the samples, including the new species (MPZ 2019/1681-1683 and MPZ 2020/483-554, Appendix I), are housed in the Natural Science Museum of the University of Zaragoza (Canudo, 2018).

\section{STRATIGRAPHY}

The biostratigraphic information obtained in this work is partly based on the revision of published material, i.e. the Isuela and Gabardiella sections (Rodríguez-Pintó et al., 2012a) and Santa Marina section (Rodríguez-Pintó et al., 2012b). The rest of the information comes from 8 new sections located at the western area of the Sierras Exteriores (Fig. 1):

\section{Santa Marina section}

The Santa Marina section (Rodríguez-Pintó et al., 2012b) (Fig. 2) was measured in the Cañada Zerrada

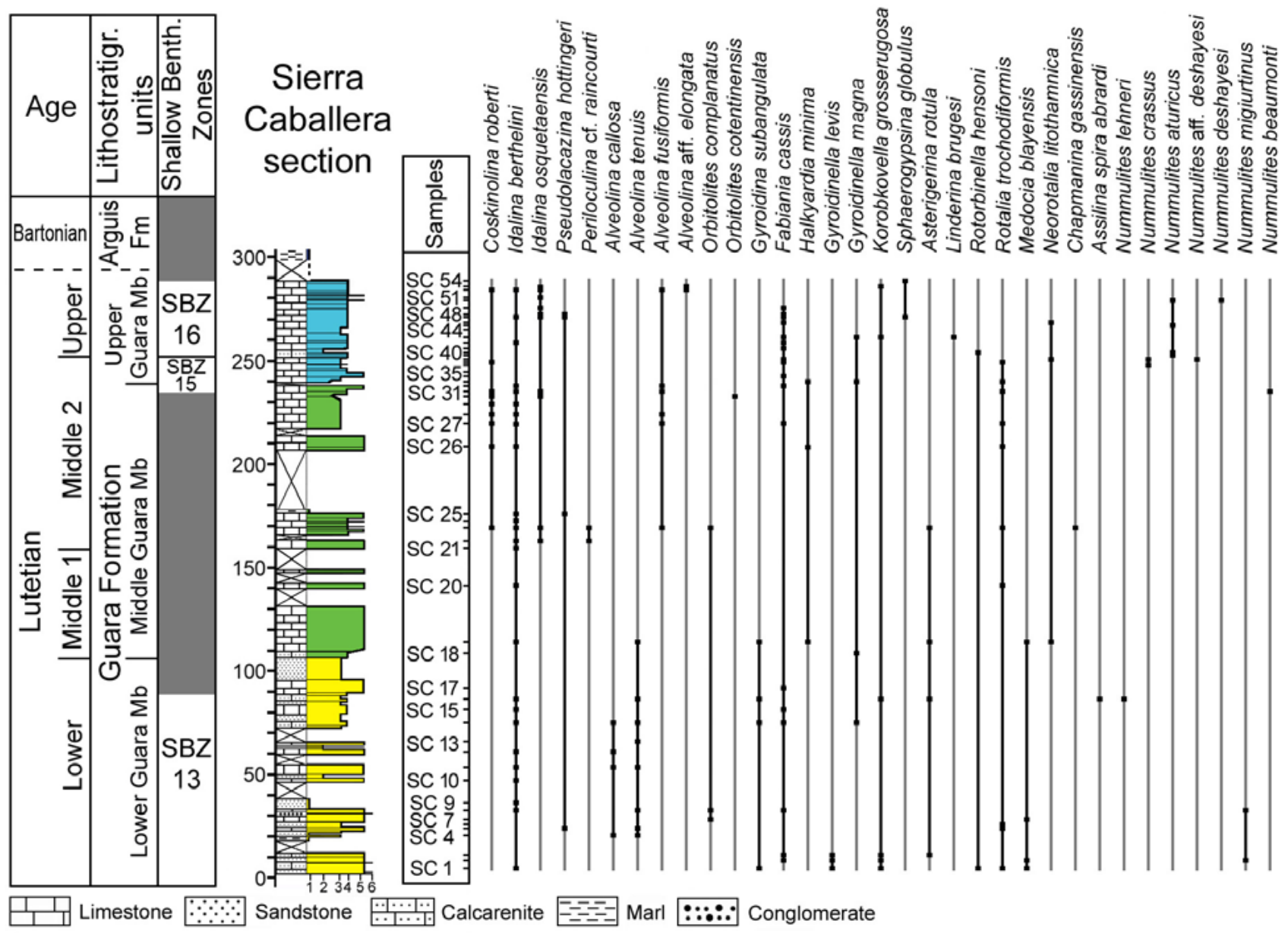

FIGURE 5. Stratigraphic succession and distribution of larger foraminifera in the Sierra Caballera section. 
gorge to the west of Santa Marina hermitage. Coordinates UTM (ETRS89): Base 30T 744240 4689823, Top 7436384689986 . The section was tentatively dated by magnetostratigraphy (Rodríguez-Pintó et al., 2012b). Unfortunately, the occurrence of a widespread reverse remagnetization component in the most part of the profile (Rodríguez-Pintó et al., 2013b) precluded achieving a reliable dating and the magnetostratigraphic data is not been considered here.

The base of the section consist of marine sandy limestones of the Boltaña Fm., Cuisian in age. The overlying rocks are represented by the following stratigraphic units:

- Lower Guara Mb., represented by a $230 \mathrm{~m}$ thick alternation of marls and limestones, locally with cross stratification and bioturbation.

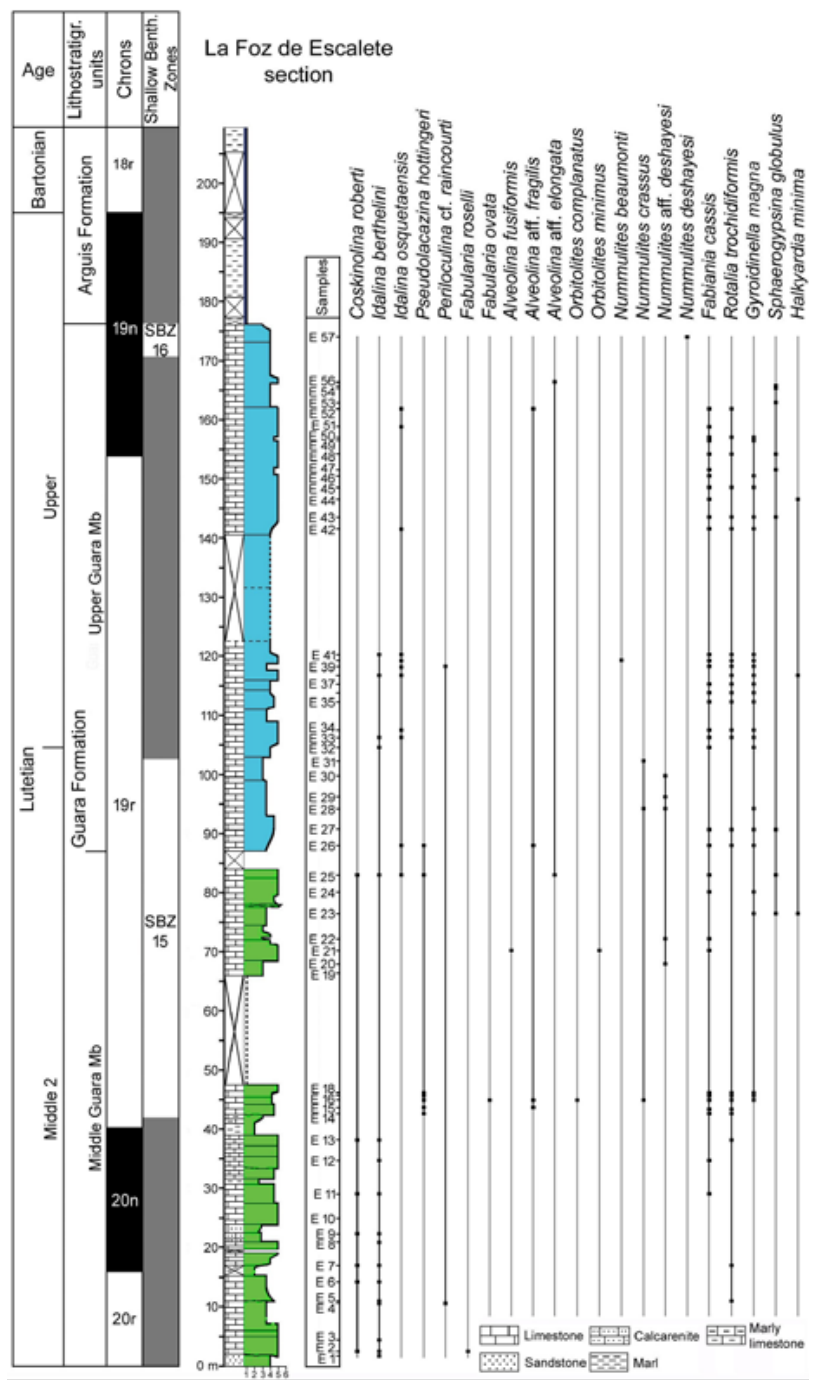

FIGURE 6. Stratigraphic succession and distribution of larger foraminifera in the La Foz de Escalete section. Magnetostratigraphic data after Silva-Casal et al. (2019).
- Middle Guara Mb., represented by 370m of limestones. The occurrence of Nummulites boussaci and Nummulites beneharnensis in the middle part of this unit characterizes SBZ 14 (middle Lutetian 1). The occurrence of Nummulites crassus and Nummulites tavertetensis in the upper part characterizes SBZ 15 (middle Lutetian 2).

- Upper Guara Mb., bounded at the base by and unconformity and represented by $15-20 \mathrm{~m}$ of limestones. The occurrence of Nummulites deshayesi characterizes SBZ 16 (late Lutetian).

- Arguis marls Fm., represented by marlstones with Nummulites perforatus which characterizes SBZ 17 (Bartonian).

\section{Gabardiella section}

The Gabardiella section (Rodríguez-Pintó et al., 2012a, 2017; Samsó et al. 1994) (Fig. 3) was measured in the eastern flank of the Gabardiella anticline, along the road between the localities of Lusera and Nocito. Coordinates UTM (ETRS89): Base 30T 722132 4688600, Top 30T $7212814688255)$.

The lowermost part of the section is composed of $75 \mathrm{~m}$ of red marls and lacustrine limestones of continental facies of the Tremp Fm. The overlying rocks consist of the following stratigraphic units:

- Boltaca Fm., consists of 30m of limestones and marls. The presence of Coskinolina cf. perpera, Alveolina decastroi and Alveolina cremae characterizes SBZ 11 (middle Cuisian). The Chron C22 was identified in this unit (Fig. 3) (Rodríguez-Pintó et al., 2017).

- Lower Guara Mb., consists of a 170m thick succesion of sandstones at the base, followed by an alternation of limestones, siltstones and marls. The presence of Alveolina obtusa, Alveolina stipes, Alveolina callosa, Alveolina ospiensis, Assilina spira abrardi and Nummulites lehneri characterizes SBZ 13 (early Lutetian). This unit includes Chron C21 and the lower part of Chron C20r (RodríguezPintó et al., 2017).

- Middle Guara Mb., is represented by $435 \mathrm{~m}$ of limestones with frequent cross-bedding and bioturbation. The ocurrence of Alveolina munieri characterizes SBZ 14 (middle Lutetian 1). The presence of $A$. aff. fragilis in the upper part of this unit, together with the correlation with Isuela section, suggests SBZ 15 (middle Lutetian 2). The lower part of this unit correlates to Chron C20r (RodríguezPintó et al., 2017).

- Upper Guara Mb., a 60m thick succession of limestones with some levels of siltstones. Despite the absence of larger foraminifera biomarkers, the correlation with the nearby Isuela section (Fig. 4) suggests SBZ 16 (late Lutetian). 


\section{Isuela section}

The Isuela section (Fig. 4) is exposed along the old road between the localities of Nueno and Arguis, in the Isuela river gorge, on the western flank of the Pico del Águila anticline. Coordinates UTM (ETRS89): Base: 30T 712081 4685921, Top: 30T 712125 4686840).

The base of the section consists of a $50 \mathrm{~m}$ thick succession of sandstones, conglomerates and lacustrine limestones of the Tremp Fm.

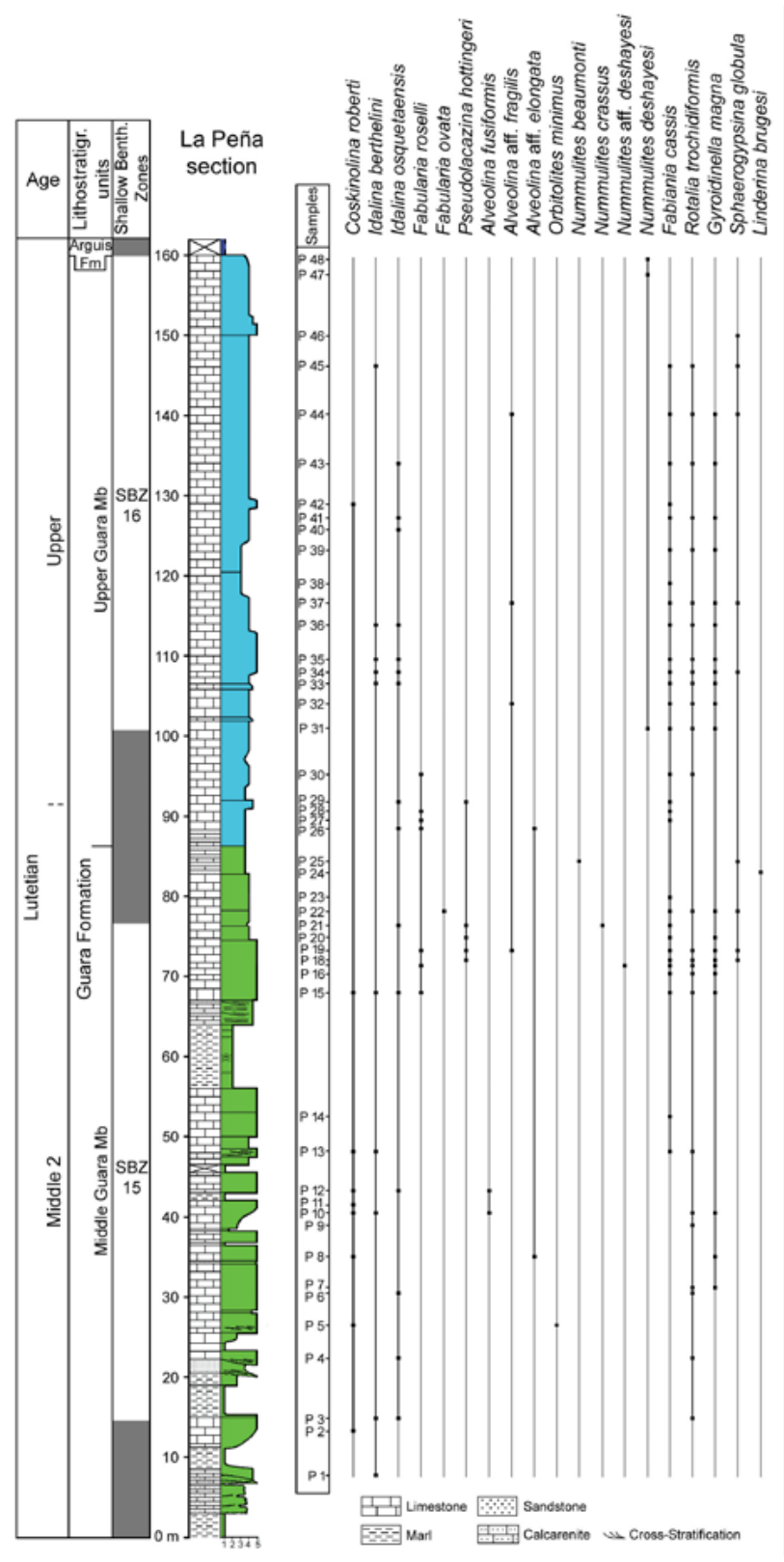

FIGURE 7. Stratigraphic succession and distribution of larger foraminifera in the La Peña section.
The overlying rocks are represented by the following stratigraphic units:

- Lower Guara Mb., composed of 95m of sandstones, conglomerates and limestones. The presence of Alveolina obtusa, A. stipes and Assilina spira abrardi characterizes SBZ 13 (early Lutetian). Chron C21 is identified in the lower part of the unit, whereas its upper part correlates to chron C20r (Rodríguez-Pintó et al., 2012a).

- Middle Guara Mb. 285m thick unit mainly composed of limestones and thin intervals of marls, siltstones, marly limestones, dolomites and dolosiltites. The presence of Alveolina munieri, Nummulites aspermontis, N. beneharnensis and $N$. praediscorbinus characterized SBZ 14 (middle Lutetian 1). The presence of $N$. beaumonti in the uppermost part of this unit indicates SBZ 15 (middle Lutetian 2). This unit spans the time interval from the latter part of Chron C20r to the early C19r (Rodríguez-Pintó et al., 2012a).

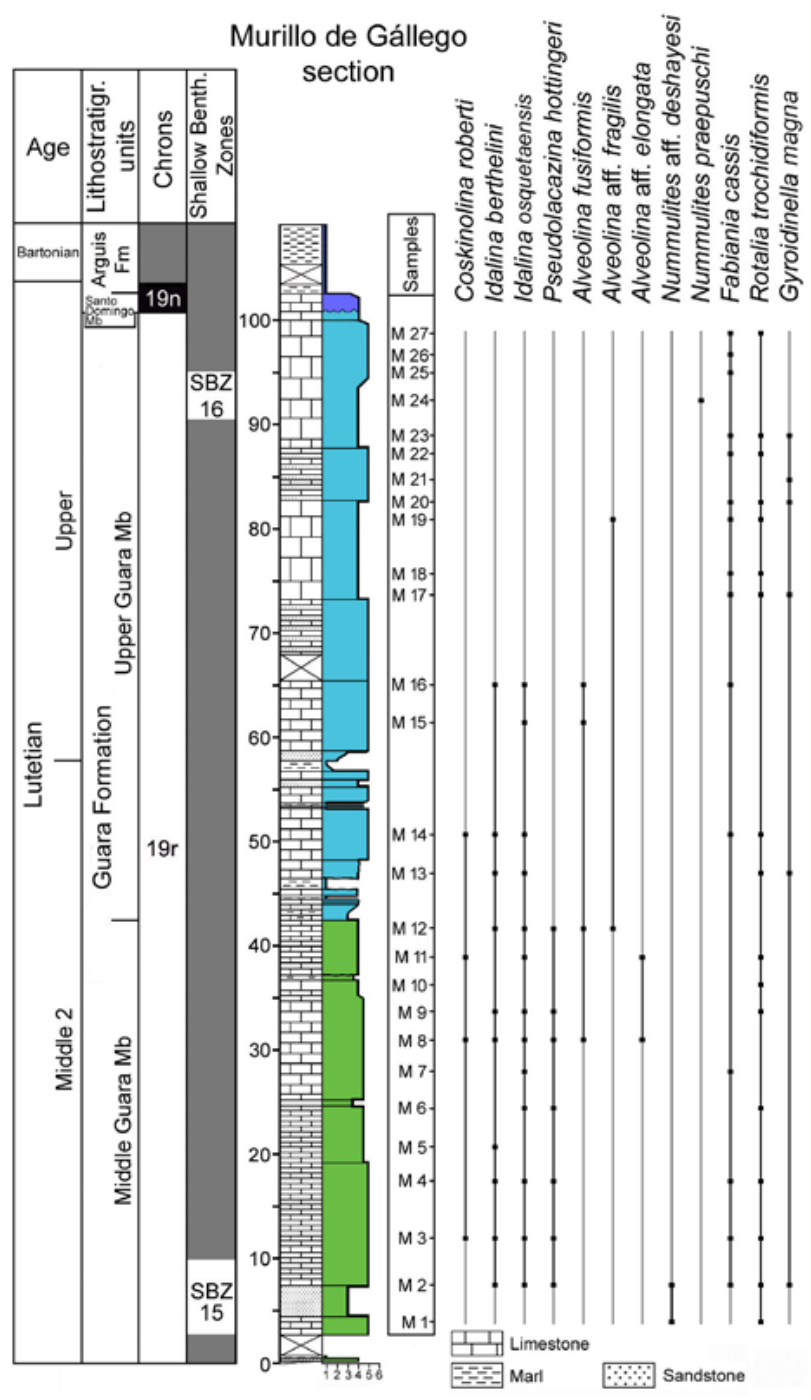

FIGURE 8. Stratigraphic succession and distribution of larger foraminifera in the Murillo de Gállego section. Magnetostratigraphic data after Silva-Casal et al. (2019). 
- Upper Guara Mb. is represented by an $88 \mathrm{~m}$ thick alternation of limestones and marly limestones. The presence of $N$. aff. deshayesi and $N$. aff. bullatus in the lower part of this unit indicates SBZ 15 (middle Lutetian 2), and $N$. deshayesi in the middle part indicates SBZ 16 (late Lutetian). Chron $\mathrm{C} 19 \mathrm{n}$ and the base of $\mathrm{C} 18 \mathrm{r}$ were identified in the upper part of this unit (Rodríguez-Pintó et al., 2012a, 2019).

\section{Sierra Caballera section}

Located in the Sierra Caballera, close to Bentué de Rasal village, the Sierra Caballera composite section is made of two subsections. The lower part was measured along an unpaved road to the south of the Foz de Portiella gorge, and the upper subsection in the gorge. Coordinates UTM (ETRS89): lower subsection Base: 30T 7023634688711 , Top: 30T 702504 4688780; upper subsection Base: 30T 7024824689969 , Top: 30T 7026584690168.

In this section the following stratigraphic units are observed (Fig. 5):

- Lower Guara Mb., composed of 108m of marls, sandstones and limestones. The presence of Alveolina

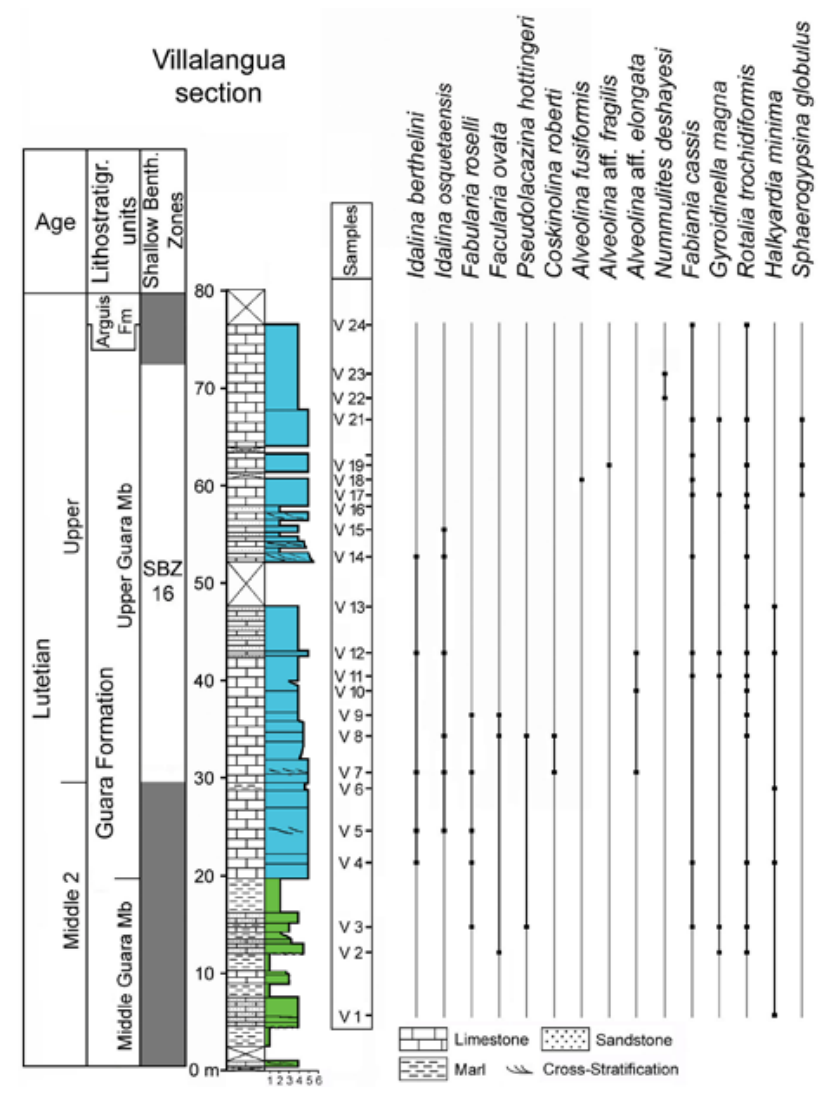

FIGURE 9. Stratigraphic succession and distribution of larger foraminifera in the Villalangua section. callosa, Assilina spira abrardi and Nummulites lehneri characterizes SBZ 13 (early Lutetian).

- Middle Guara Mb. is a $127 \mathrm{~m}$ thick unit mainly composed of limestones, but thick intervals are covered. The presence of $N$. beaumonti in the upper part of this unit indicates SBZ 15 (middle Lutetian 2). SBZ 14 (middle Lutetian 1) biostratigraphic markers were not found.

- Upper Guara Mb. is a unit is mainly composed of limestones, with a minimum thickness of $55 \mathrm{~m}$, as its upper part could not be measured because the boundary with the Arguis Fm. is covered. . The presence of N. crassus and N. aff. deshayesi in the lower part of this unit indicates SBZ 15 (middle Lutetian 2) and the presence of $N$. aturicus and $N$. deshayesi in the middle and upper part indicates SBZ 16 (late Lutetian).

\section{La Foz de Escalete section}

Located along the Foz de Escalete gorge (Silva-Casal, 2017), near La Peña Estación village. Coordinates UTM (30T): Base 30T 689436 4693642, Top 30T 689543 4693952).

The following stratigraphic units have been recognized (Fig. 6):

- Middle Guara Mb., 84m thick succesion composed of sandstones at the base, followed by limestones with thin intervals of marls, sandstones, marly limestones and limestones. The presence of $N$. crassus and $N$. aff. deshayesi indicates SBZ 15 (middle Lutetian 2). Chron C20 and the lower part of C19r were identified in this unit (Silva-Casal, 2017).

- Upper Guara Mb. is composed here of 178m thick limestones. The presence of $N$. crassus and $N$. aff. deshayesi in the lower part of this unit indicates SBZ 15 (middle Lutetian 2), and $N$. deshayesi in upper part indicates SBZ 16 (late Lutetian). Chron C19r was identified in the lower part and C19n in the upper part (Silva-Casal, 2017).

- Arguis Fm. is represented in this section by a $1000 \mathrm{~m}$ thick marly succession including intervals of marly limestones and sandstones (Millán et al., 1994). The lowermost Arguis Fm. consists of an alternation of marls and siltstones. The upper part of Chron C19n and its boundary with Chron C18r were identified in this unit (Silva-Casal, 2017; Silva-Casal et al., 2019).

\section{La Peña section}

Located along the road A-132 next to La Peña dam, in the proximity of Santa María de la Peña village (SilvaCasal, 2017). Coordinates UTM (ETRS89): Base 30T 6859524694793 , Top 30T 6863234694917.

This section is composed of the following stratigraphic units (Fig. 7): 
- Middle Guara Mb., 87m thick, composed of marls and limestones with cross stratification. The presence of $N$. crassus and $N$. aff. deshayesi indicates SBZ 15 (middle Lutetian 2).

- Upper Guara Mb., composed of $73 \mathrm{~m}$ of massive limestones. The presence of $N$. deshayesi indicates SBZ 16 (late Lutetian).

\section{Murillo de Gállego section}

Located in the north-west of the Murillo de Gállego village (Silva-Casal, 2017). Coordinates UTM (ETRS89): Base 30T 685553 4692400, Top 30T 685490 4692302).

In this section the following stratigraphic units have been observed (Fig. 8):

- Middle Guara Mb. a 43m thick unit composed of limestones with thin marly intervals. The presence of $N$. aff. deshayesi at the base of this unit indicates SBZ 15 (middle Lutetian 2). Chron C19r extends throughout this unit (Silva-Casal, 2017; Silva-Casal et al., 2019).

- Upper Guara Mb. formed of a 59m thick alternation of massive limestones with some intervals of laminated limestones. The presence of $N$. praepuschi in the upper part of this unit indicates SBZ 16 (late Lutetian). This unit belongs to the upper part of Chron C19r (Silva-Casal, 2017; Silva-Casal et al., 2019). The contact surface with the overlying Santo Domingo Mb. is an unconformity.

- Arguis Fm., constituted by $1.5 \mathrm{~m}$ of glaucontic limestones of the Santo Domingo Mb. at the base, passing upwards into the typical blue marls of the Arguis Fm. Chron C19n was identified at the base of the Santo Domingo Mb. (Silva-Casal, 2017; Silva-Casal et al., 2019).

\section{Villalangua section}

This section is exposed along an unpaved road between the locality of Villalangua and the abandoned village of Salinas Viejo. The top of the section is complemented with data from the nearby Salinas gorge (Silva-Casal, 2017) Coordinates UTM (ETRS89) are: Base 30T 679218 4697917, Top 30T 679236 4697975. Salinas gorge: 30T 6801154697682.

This section includes the following stratigraphic units (Fig. 9):

- Middle Guara Mb., 20m thick succesion of marls and limestones. Despite the absence of larger foraminifera biostratigrahic markers, lithological correlation with nearby sections allows the attribution of this unit to SBZ 15 (middle Lutetian 2).

- Upper Guara Mb., composed of $57 \mathrm{~m}$ of cross stratified limestones, laminated limestones and massive limestones. The presence of $N$. deshayesi at the top of this unit indicates SBZ 16 (late Lutetian).

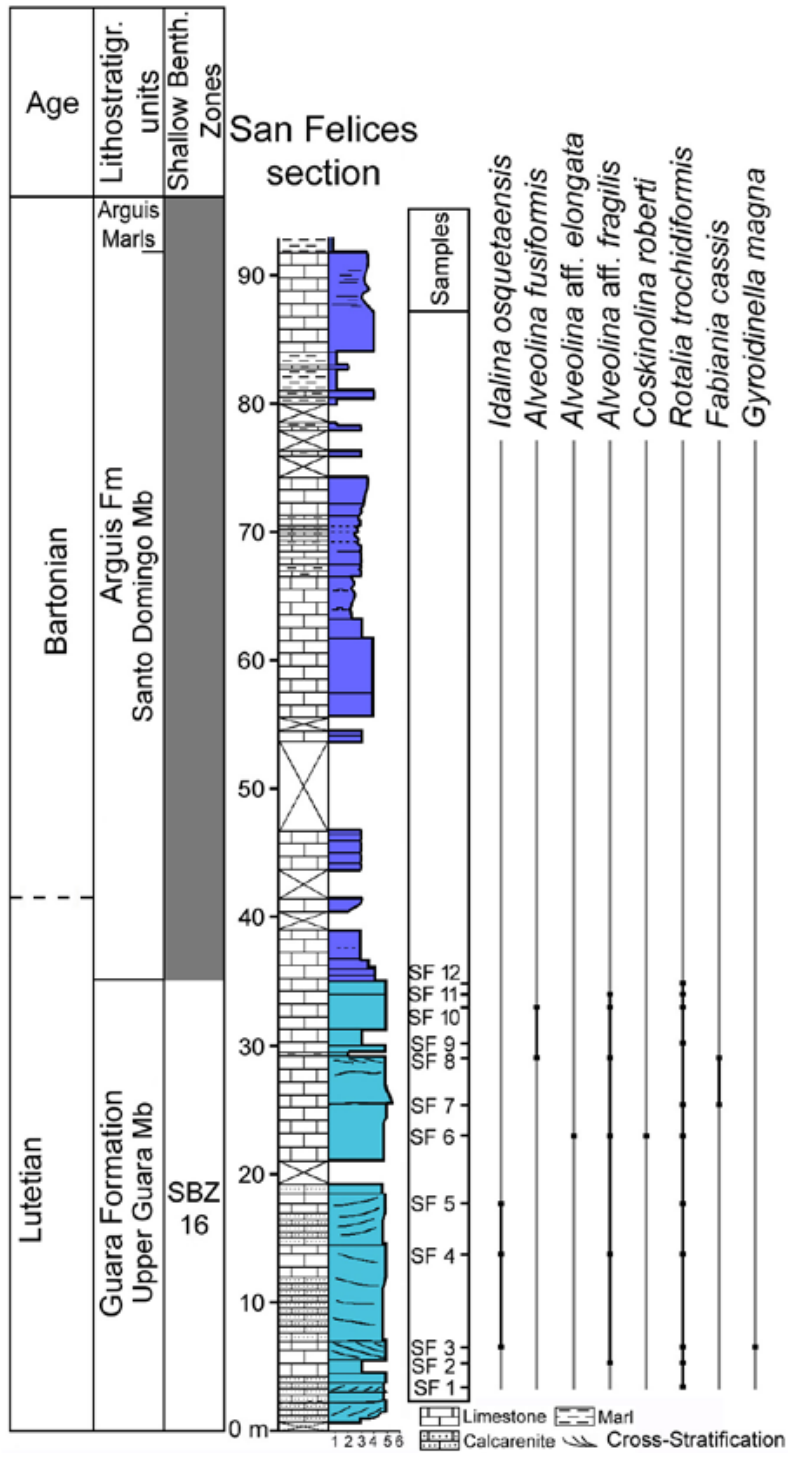

FIGURE 10. Stratigraphic succession and distribution of larger foraminifera in the San Felices section.

\section{San Felices section}

Located at the Barranco del Villano gorge, to the northeast of San Felices (Agüero) village (Silva-Casal, 2017). The section is divided into two subsections. The upper subsection is located on an unpaved road, whereas the lower part of the section is located at the bottom of the Barranco del Villano gorge with coordinates UTM (ETRS89): Lower subsection Base 30T 679479 4694017, Top 30T 679540 4693925; Upper subsection Base 30T 6794504693974 , Top 30T 679434 4693927).

In this section the following stratigraphic units can be observed (Fig. 10):

- Upper Guara Mb., 35m thick, consists of cross stratified limestones. Despite the absence of larger 
foraminifera biostratigraphic markers, stratigraphic correlation with other sections allows the attribution of this unit to SBZ 16 (late Lutetian).

- Santo Domingo Mb. $57 \mathrm{~m}$ thick, is composed of marly limestones with some marly intervals. Despite the absence of larger foraminifera biostratigraphic markers, the correlation to other nearby sections shows that this unit is early Bartonian in age (SBZ 17).

\section{La Osqueta section}

Located on an unpaved road in proximity to $\mathrm{La}$ Osqueta pass and conplemented (from meters 50 to 60) with data from the La Osqueta pass itself (Silva-Casal, 2017) Coordinates UTM (ETRS89) are: Base 30T 680560 4696568, Top 30T 6803104696553 . La Osqueta pass: 30T 6795894696809.

The base of the section is composed of $20 \mathrm{~m}$ of lacustrine limestones and red lutites of the Tremp Fm.

The overlying Eocene rocks are represented by the following stratigraphic units (Fig. 11):

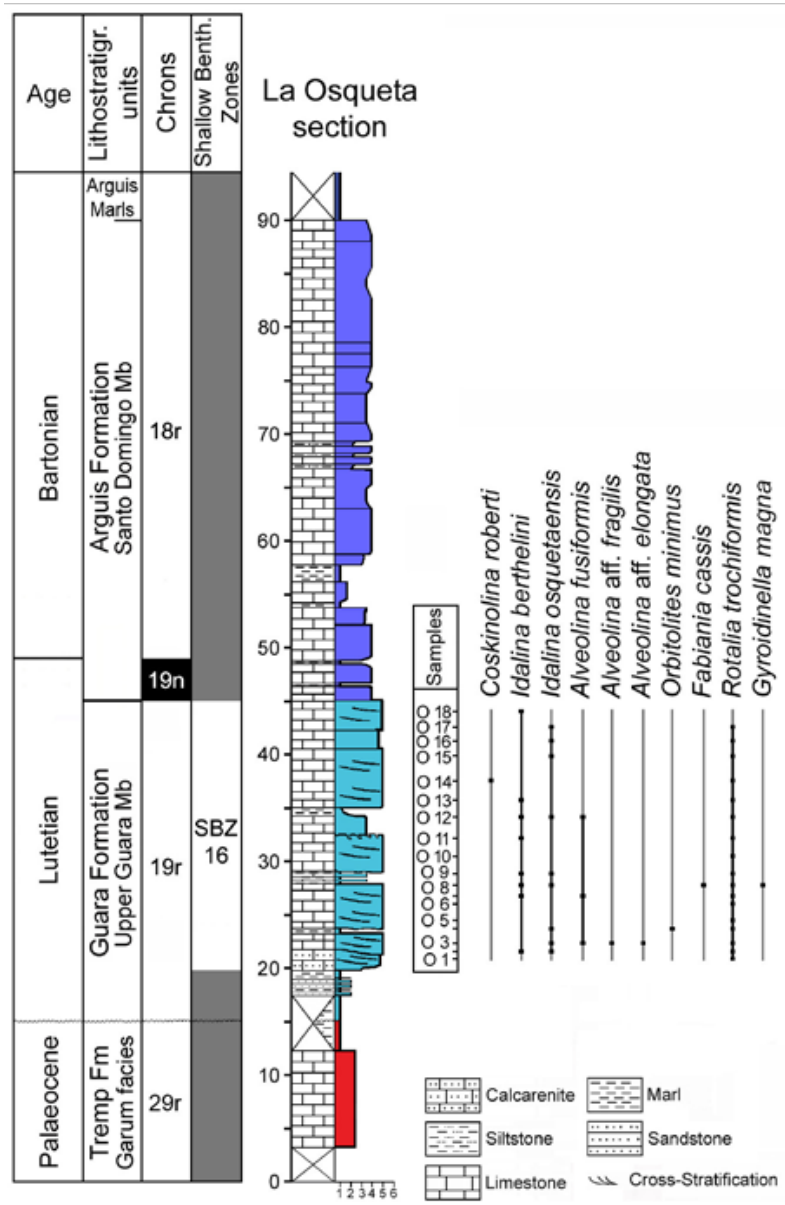

FIGURE 11. Stratigraphic succession and distribution of larger foraminifera in the La Osqueta section. Magnetostratigraphic data after Silva-Casal et al. (2019).
- Upper Guara Mb., 25m thick, is composed of limestones. Despite the absence of larger foraminifera biostratigraphic markers, the stratigraphic correlation with other sections allowed to assign this unit to SBZ 16 (late Lutetian). Chron C19r was found in this unit (Silva-Casal, 2017).

- Santo Domingo Mb. is represented by $45 \mathrm{~m}$ of marly limestones and marls. Despite the absence of biostratigraphic markers of larger foraminifera the stratigraphic correlation with other sections indicates that the upper part of this unit belongs to the SBZ 17 (early Bartonian). In this unit the chrons C19n and C18r have been identified (Silva-Casal, 2017; Silva-Casal et al., 2019).

\section{Campo Fenero section}

This section is located in the Sierra de Santo Domingo range, west to the source of the Arba de Biel river (SilvaCasal, 2017). This section is located along a path from a mountain hut leading to the Campo Fenero with coordinates UTM (ETRS89): Base: 30T 672841 4699265, Top: 30T 6726894699288 . The base of the section is composed of $5 \mathrm{~m}$ of sandstones and red lutites of the Tremp Fm.

The overlying succession (Fig. 12) is represented by the Santo Domingo Mb., mainly constituted of cross stratified limestones interspersed with marls and sandstones. The presence of Nummulites biarritzensis and $N$. beaumonti in the middle part of this unit indicates SBZ 17 (Bartonian).

\section{SYSTEMATIC PALEONTOLOGY (FORAMINIFERA) by J. Serra-Kiel et R. Silva-Casal}

Note: The biostratigraphic study is based on the zonation of Drobne (1977), Hottinger (1960, 1974), Hottinger and Drobne (1988), Schaub (1981) and SerraKiel et al. (1998).

Phylum: Foraminifera EICHWALD, 1830

Class: Tubothalamea PAWLOWSKI, OHOLZMANN, JAROSLAW AND TYSZKA, 2013

Order: Miliolida DELAGE AND HÉROUARD, 1896

Superfamily: Milioloidea EHRENBERG, 1839

Family: Hauerinidae SCHWAGER, 1876

Subfamily: Miliolinellinae VELLA, 1957

GENUS Idalina SCHLUMBERGER AND MUNIERCHALMAS, 1884

Type species: Idalina antiqua SCHLUMBERGER AND MUNIER-CHALMAS, 1884

Idalina sp.

Figs. 13A-E; 14A-C 
Material. This species has been identified in the Gabardiella section (Fig. 3).

Description. Test porcellaneous with miliolid growth. Dimorphism marked. The microspheric forms display a spherical morphology, the major length for 5 whorls is $1.85 \mathrm{~mm}$. The nepionic stage is formed by a small proloculus $0.60 \mu \mathrm{m}$ in diameter followed by one quinqueloculine whorl. The ephebic stage shows a bilocular growth. The basal layer is thin and locally slightly undulate. The megalospheric forms show an elliptical outline in sections perpendicular to the coiling axis. The nepionic stage is formed with a proloculus $120 \mu \mathrm{m}$ in diameter followed by one quinqueloculine stage. The ephebic stage shows a bilocular arrangement of the chambers. The maximum length in axial section is $1.4 \mathrm{~mm}$. The basal layer is thin.

Remarks. No formal species have been described within genus Idalina in the Cuisian yet. However, Drobne (1988) documented two forms assigned to Idalina sp. in the Cuisian of Dalmatia (p. 653, figs. 6.5 and 6.6, op. cit.). They differ from the specimens studied in the thickness of the basal layer and the size of the test. The scarcity of available material did not allow us to describe this species as a new species.

Age. This species is associated with Alveolina cremae and $A$. decastroi (samples $\mathrm{G} 1$ and $\mathrm{G} 2$; Fig. 3), indicating middle Cuisian (A. dainellii Zone) (Hottinger, 1960) or SBZ 11 (Serra-Kiel et al., 1998).

\section{Idalina berthelini SCHLUMBERGER, 1905}

Figs. 13F-V; 14D-Q

1905 Idalina berthelini $\mathrm{n}$. sp. Schlumberger, p. 120122; text-figs. 7-9; pl. 2 figs. 33, 33a

1962 Idalina cf. berthelini. Escandell and Colom, p. 119; fig. 18

1975 Idalina berthelini. Colom, p. 226; fig. 81, without scale

2012a Idalina berthelini Schlumberger, 1905. Rodríguez-Pintó et al., on-line Supplementary Material, pl. 9, figs. 1-8

2013a Idalina berthelini Schlumberger, 1905. Rodríguez-Pintó et al., figs. 8-10.

Material. This species has been identified in the following sections: Gabardiella, Isuela, Sierra Caballera, La Foz de Escalete, La Peña, Murillo de Gállego, Villalangua and La Osqueta (Figs. 2; 3; 5-9; 11).

Description. The megalospheric forms show an ovoidsubspherical morphology. The proloculus is spherical with a diameter between $150-220 \mu \mathrm{m}$ followed by a flexostyle (Fig. 13F, H, I, U). The nepionic stage is formed of two chambers in triloculine arrangement (Fig. 13L) or of one first biloculine

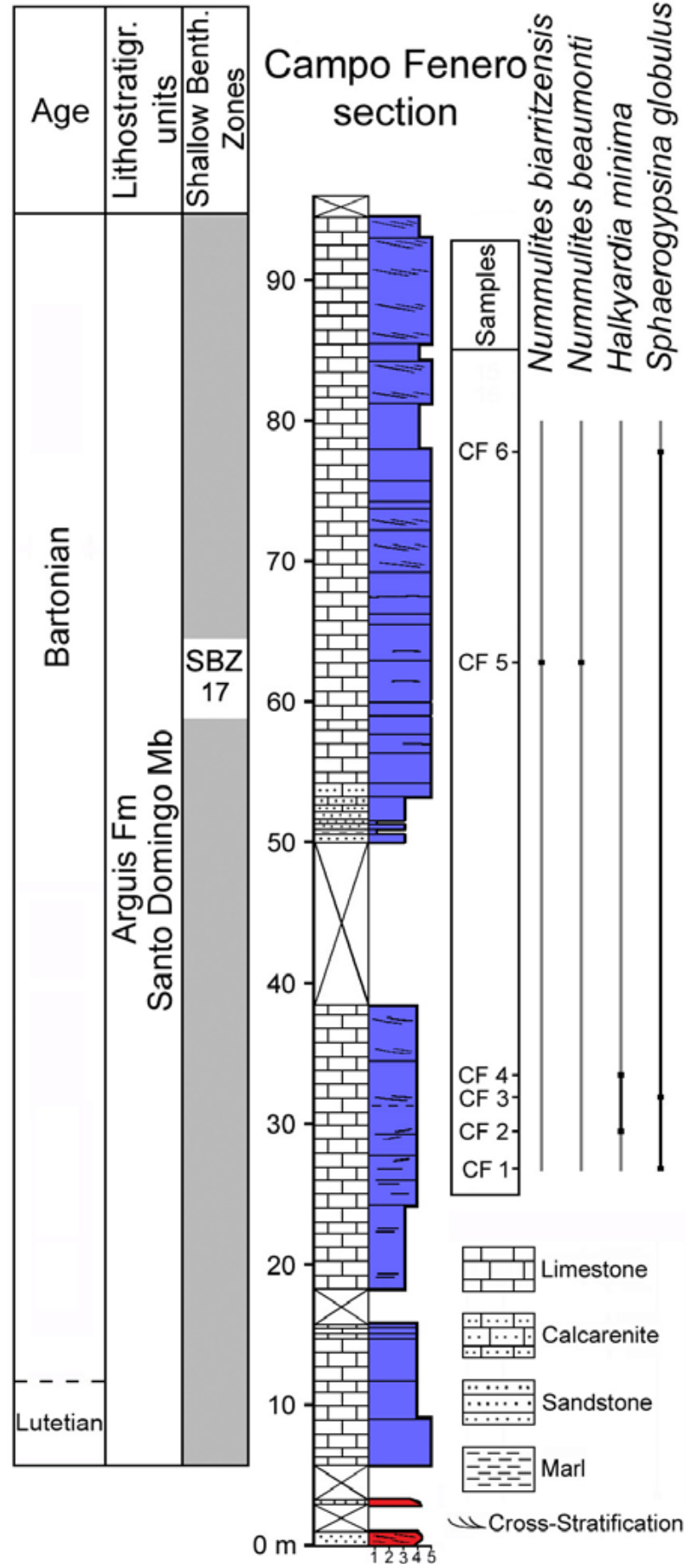

FIGURE 12. Stratigraphic succession and distribution of larger foraminifera in the Campo Fenero section.

growth stage followed by one triloculine growth stage (Fig. 13F). The neanic stage displays a biloculine arrangement of the chambers in the remaining whorls (Fig. 13F, H, I, J, $\mathrm{K}, \mathrm{L}, \mathrm{S})$. The dimensions of the test vary between $1.7-2 \mathrm{~mm}$ in axial section and $1.6-2 \mathrm{~mm}$ in the longitudinal section. The microspheric forms show a subspherical morphology. Dimorphism is little marked. The initial growth is formed of 2-3 cycles pluriloculine in arrangement, showing then 1-2 
cycles with quinqueloculine arrangement, followed by one triloculine cycle. The remaining whorls follow the biloculine mode (Fig. 13N-P). The diameter of axial section varies between $1.8-2.3 \mathrm{~mm}$ for $4-5$ biloculine chambers. In both generations the basal layer is slightly undulate and does not exceed half of the height of the chamber. The trematophore is supported by strong pillars (Fig. 13Q, R).

Remarks. The megalospheric forms of the studied material display the nepionic stage either in biloculine, triloculine or quinqueloculine arrangement in its first chambers. This polymorphism was pointed out by Schlumberger (1905), who described the nepionic stage of the megalospheric forms with the two first chambers either in biloculine (Fig. 7 left, op. cit.) or quinqueloculine mode (Fig. 7 centre and right, op. cit.).

Age. The biostratigraphic range of Idalina berthelini extends from early Lutetian (SBZ 13) to late Lutetian (SBZ 16). The inclusion of Idalina berthelini in SBZ 13
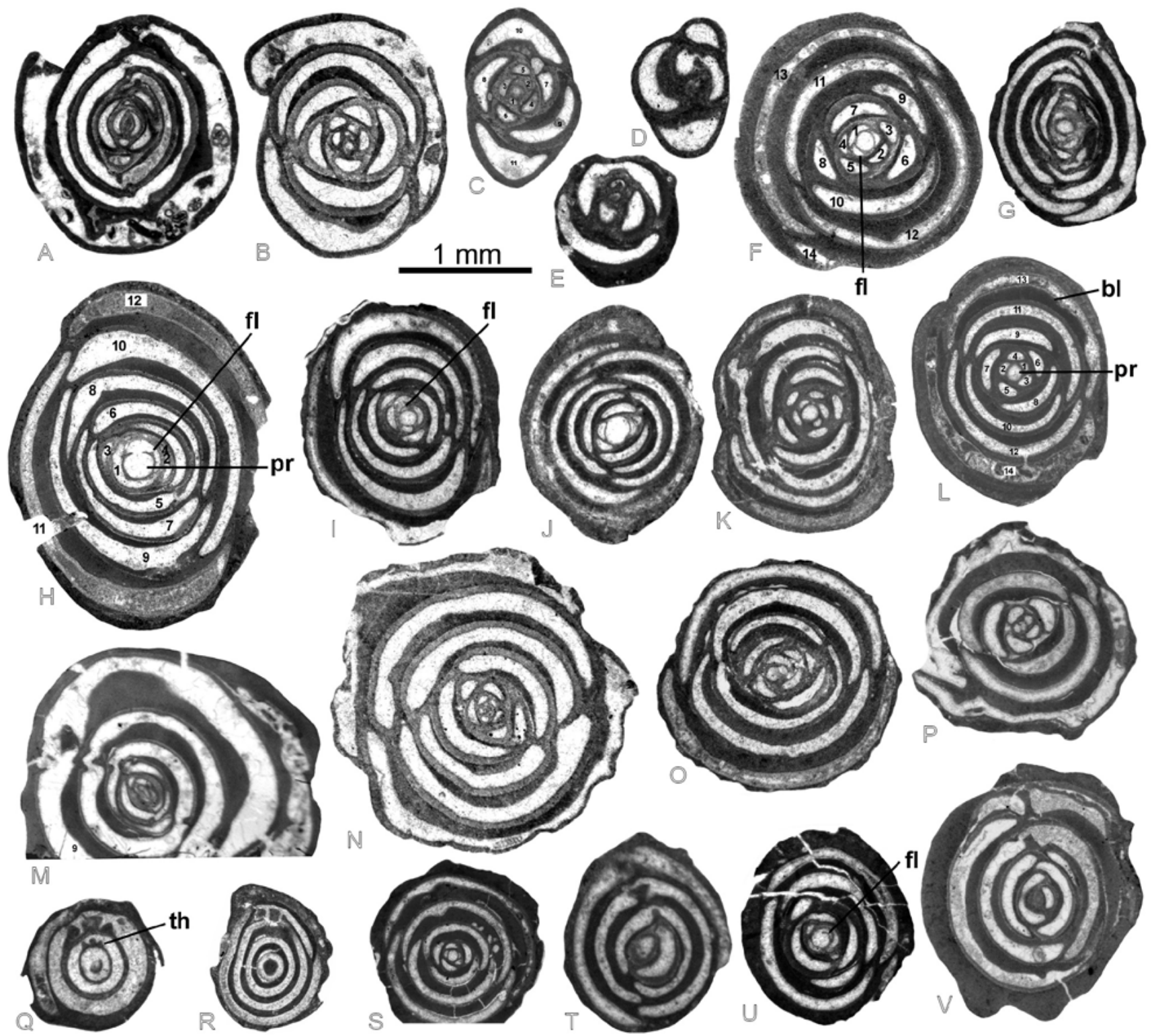

FIGURE 13. SA-E) Idalina sp. 1, longitudinal section, microspheric form. B: axial section. C: axial section, megalospheric form. D, E: oblique sections. Specimens A, C, E: sample G 1 and B, D: sample G 2. F-V) Idalina berthelini. F: centered axial section, megalosferic form. G: Iongitudinal section. $\mathrm{H}$-J: oblique centered axial sections, megalospheric forms. K, L: centered axial sections, megalospheric forms. M: almost centered longitudinal section, microspheric form. N: centered axial section, microspheric form. O, P: slightly uncentered axial section, microspheric form. Q, R: peripheral longitudinal sections. S: centered axial section, megalospheric form. T: uncentered longitudinal section. U: oblique centered axial section, megalospheric form. V: uncentered longitudinal section. Specimens F: sample G 28; G, I: sample I 45; H: sample I 47; J: sample I 42; K: sample I 38; L: sample G 60; M: sample I 22; N: sample G 13; O: sample I 44; P: sample G 35; Q: sample I 39; R: sample I 37; S: sample G 36; T: sample I 40; U: sample G 27 and V: sample I 17. Abbreviations: fl: flexostyle; pr: proloculus; bl: basal layer; th: trematophore. 


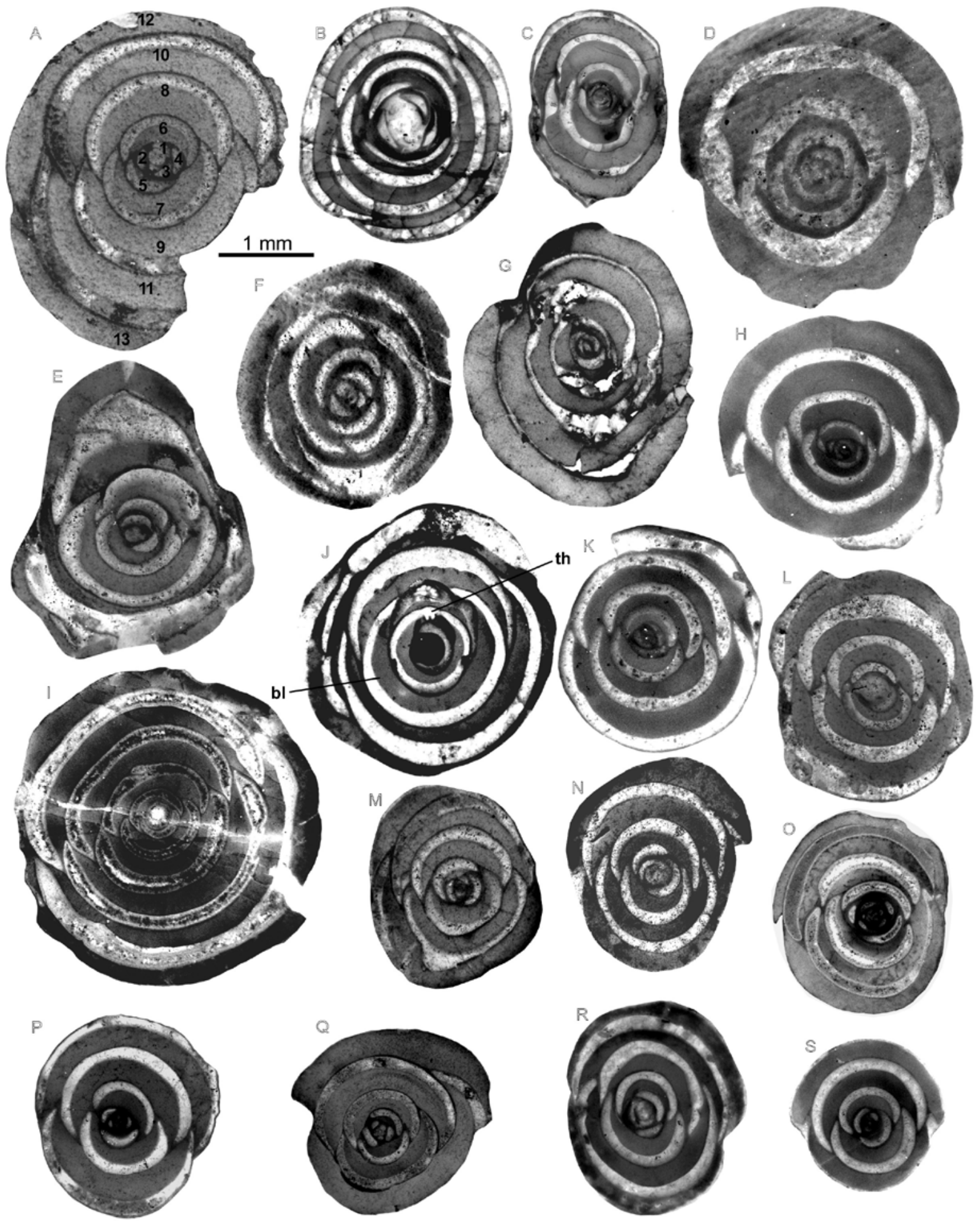

FIGURE 14. Differences between the size of the shell and the thickness of the basal layer between Idalina sp. (middle Cuisian), and the Lutetian forms Idalina berthelini and Idalina osquetaensis. A-C) Idalina sp. A: drawing from Figure 13A. B: drawing from Figure 13B. C: drawing from Figure 13C. D-Q) Idalina berthelini. D: drawing from Figure 13G. E: drawing from Figure 13U. F: drawing from Figure 13S. G: drawing from Figure 13J. Specimen H: sample I 38. I: sample I 9. J: drawing from Figure 13L. K: drawing from Figure 13N. L: drawing from Figure 13M. M: drawing from Figure 13H. N: drawing from Figure 13F. O: specimen from sample 0 12. P-A') Idalina osquetaensis $\mathrm{n}$. sp. P: drawing from Figure 15A. Q: drawing from Figure 15D. R: drawing from Figure 15E. S: drawing from Figure 15F. T: drawing from Figure 15I. U: drawing from Figure 15G. V: drawing from Figure 15B. W: specimen from sample 0 5. X: specimen from sample 0 9. Y: drawing from Figure 15J. Z: drawing from Figure 15H. $A^{\prime}$ : drawing from Figure 15C. 

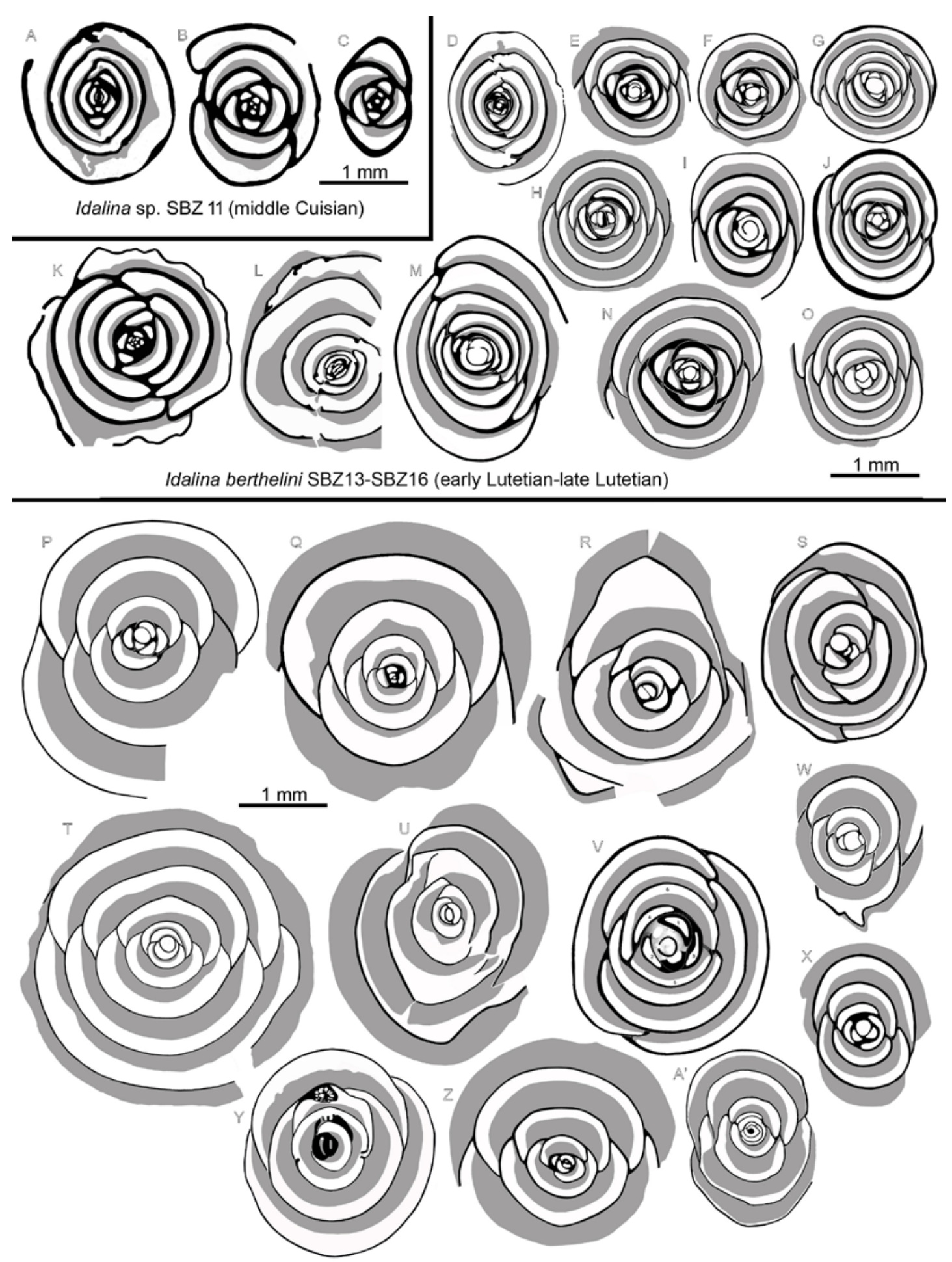

Idalina osquetaensis SBZ15-SBZ16 (middle Lutetian 2-late Lutetian)

FIGURE 15. A-S) Idalina osquetaensis n. sp. A (Holotype, MPZ 2019/1681): centered axial section, megalospheric form; note the quinqueloculine nepionic stage, the size of the shell and the thickness of the basal layer. B: slightly oblique axial sections. C, D: uncentered axial sections, megalospheric forms. E (Paratype, MPZ 2019/1683): uncentered axial section, megalospheric form; note the thickness of the basal layer. F (Paratype, MPZ 2019/1682): slightly oblique axial section. G: slightly oblique longitudinal section, microspheric form. H: axial section, microspheric form. I: centered axial section, megalospheric form. J: subaxial section; note the trematophore. K: axial sections, microspheric form. L: uncentered axial sections, megalospheric form. $\mathrm{M}, \mathrm{N}$ : uncentered axial sections, possible microspheric forms. O: axial sections, microspheric forms. P, Q: uncentered axial sections, possible microspheric forms. R: centered axial section, megalospheric form. S: uncentered axial section, possible microspheric form. Specimens A, E, F: sample O 3; B: sample P 21; C: sample V 9; D: sample O 2; G: sample E 33; H, K: sample M 16; J: sample V 15; L: sample O 17; I, O: sample SC 52; M: sample E 40; N: sample P 33; P: sample M 8; Q: sample V 14; R: sample V 7 and S: sample M 15. Abbreviations: bl: basal layer; th: trematophore. 
is based on its association with Alveolina stipes (samples G 19, G 21 and I 2; Figs. 3; 4), A. obtusa (sample I 1; Fig. 4), and A. callosa (samples SC 11, SC 12 and SC 14; Fig. 5), which indicates the A. stipes Zone, (early Lutetian), or with Assilina spira abrardi (sample I 7 and SC 16; Figs. 4; 5) and Nummulites lehneri (sample SC 16; Fig. 5), indicating the N. laevigatus-N. obesus Zone (early Lutetian). The SBZ14 is characterized by the association with $A$. munieri (samples G $23, \mathrm{G} 24, \mathrm{G} 35, \mathrm{G} 36$, I 16, I 17 , I 20 and I 22; Figs. 3; 4), indicating the A. munieri Zone, (middle Lutetian 1). The SBZ15 is characterized by the association of $I$. berthelini with $N$. aff. deshayesi (sample M 2; Fig. 8). Its occurrence in beds underlying beds that contain $N$. crassus (see Fig. 5) indicates the N. sordensis-N. crassus Zone (middle Lutetian 2). Finally, the SBZ16 is characterized by the presence of $I$. berthelini intercalated with samples of $N$. aturicus (sample SC 39, SC 40 and SC 45; Fig. 5), indicating the N. aturicus Zone (late Lutetian).

Idalina osquetaensis new species SERRA-KIEL ET SILVACASAL

$$
\text { Figs. 15A-S; 14P-A' }
$$

Derivation of name. The specific name refers to $\mathrm{La}$ Osqueta Pass, within the municipality of Las Peñas de Riglos (Huesca, Spain).

Holotype. Specimen MPZ 2019/1681 (Fig. 15A).

Paratypes. Specimens MPZ 2019/1683 (Fig. 15E) and MPZ 2019/1682 (Fig. 15F).

Type Localit. Located in La Osqueta section. Sample O 3 (coordinates UTM (ETRS89). 30T 680489 4696570).

Type leve. Guara Fm., middle Lutetian 2-late Lutetian (SBZ 15-SBZ16).

Material. Sample O 3 from La Osqueta section (Fig. 11).

Material. This species occurs in the following sections: Sierra Caballera, La Foz de Escalete, La Peña, Murillo de Gállego, Villalangua, San Felices and La Osqueta (Figs. 5-11).

Description. The microspheric and megalospheric forms show an ovoid morphology in longitudinal section and a subcircular outline in sections perpendicular to the coiling axis. The maximum diameter observed in megalospheric forms in axial section is $3.5 \mathrm{~mm}$. The proloculus is spherical with a diameter around $180 \mu \mathrm{m}$, followed by five chambers arranged in quinqueloculine mode; the remaining whorls follow the biloculine mode (Fig. 15A). The trematophore is supported by short pillars
(Fig. 15J). The basal layer is very thick, smooth and slightly undulate, exceeding half of the height of the chamber.

Remarks. The size of the test and the thickness of the basal layer of this species are greater than those of the species $I$. berthelini described above. The size of the test and the thickness of the basal layer increase following an evolutionary trend from Idalina sp. (Cuisian) to I. berthelini and I. osquetaensis (Lutetian) (Fig. 14).

Age. The biostratigraphic range of Idalina osquetaensis extends from middle Lutetian 2 (SBZ15) to late Lutetian (SBZ16). The SBZ15 is characterized by the association of this species with Nummulites aff. deshayesi (sample M 2; Fig. 8), and the SBZ16 is characterized by the alternation of samples containing I. osquetaensis and samples with of $N$. aturicus (samples SC 39, SC 40, SC 45 and SC 51; Fig. 5).

Superfamily: Alveolinoidea EHRENBERG, 1839

Family: Fabulariidae EHRENBERG, 1839

GENUS Fabularia DEFRANCE, 1820

Type species: Fabularia discolites DEFRANCE IN BRONN, 1825

Fabularia roselli CAUS, 1979

Fig. 16A-O

1976 Fabularia sp. CAUS, p. 26; figs. 1.1, 1.2

1979 Fabularia roselli n. sp. CAUs, p. 31, 33; text-fig. 2; pl. 1, figs. 1-13

1988 Fabularia roselli Caus. Drobne, figs. 8.13-8.14

2012a Fabularia roselli Caus, 1979.

Rodríguez-Pintó et al., on-line Supplementary Material, pl. 7, figs. 1-5; pl. 8, figs. 1-12

2013a Fabularia roselli Caus, 1979. Rodríguez-Pintó et al., figs. 4-6

Material. This species occurs in the Gabardiella, Isuela, La Foz de Escalete, La Peña and Villalangua sections (see Figs. $3 ; 4 ; 6 ; 7 ; 9$ ).

Description. The megalospheric forms show an ovoid morphology and a subcircular outline in axial section. The proloculus is spherical with a diameter between 195$260 \mu \mathrm{m}$, followed by a flexostyle (Fig. 16F, N). The neanic stage is formed of chambers in biloculine arrangement (Fig. 16G-H, L-O). The axial length measured for 4-5 biloculine chambers varies between $1.5 \mathrm{~mm}$ and $1.9 \mathrm{~mm}$. The basal layer is thick and can reach the same height as the chamberlets (Fig. 16F, G, L-O). The basal layer exhibits the anastomosed passages in irregular distribution (Fig. 16J). The apertural system in polar location is formed of a trematophore with apertures in cribrate distribution and supported by pillars (Fig. 16I, K). The septula reach the ceiling of the chamber subdivided into almost regular chamberlets (Fig. 16F-G, L-O). The microspheric forms show an ovoid-subspherical 


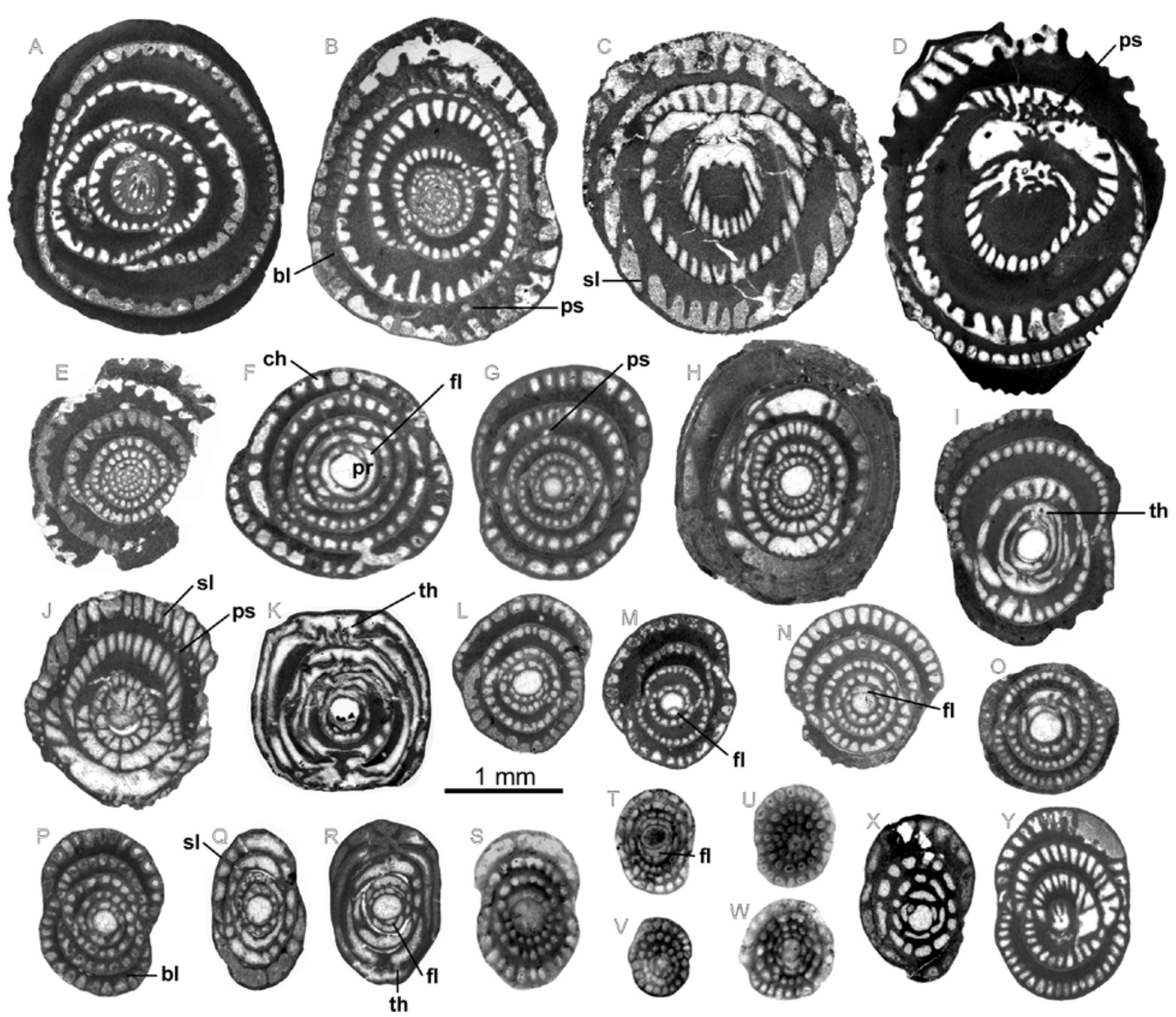

FIGURE 16. A-O) Fabularia roselli. A: uncentered axial section, microspheric form. B: centered axial section, microspheric form. C, D: oblique sections, microspheric forms; note the passage in the basal layer. E: centered axial sections, microspheric form. F-H: centered axial sections, megalospheric forms; note the flexostyle. I: centered slightly oblique axial section; note the trematophore. J: uncentered slightly oblique axial section; note the passages in the basal layer. K: centered longitudinal section; note the pillars and foramens in the trematophore. L-O: centered axial sections, megalospheric forms; note the flexostyle in N. Specimens A, D, I, K, L, M: sample G 21; B: sample G 20; C: sample I 1; F, N: sample G 18; E: sample G 12; G: sample G 16; H, O: sample G 19 and J: from sample I 2. P-Y) Fabularia ovata. P: centered axial section. Q-R: slightly oblique axial sections; note the flexostyle and trematophore in R. S-T: centered axial sections. U-W: uncentered axial sections. X: slightly oblique axial sections. Y: subaxial section. Specimen P from sample G 18; Q, R, Y: sample G 9; S, U, W: sample V 9; T: sample E 16; V: sample P 22 and X: sample I 32. Abbreviations: bl: basal layer; th: trematophore; ch: chamberlet; ps: passage; pr: proloculus; fl: flexostyle; sl: septulum.

morphology. The axial section shows a subcircular outline slightly depressed at the junction of the chambers (Fig. 16A, $B)$. The nepionic stage is formed of 2-3 quinqueloculine chambers with quinqueloculine arrangement, followed by the neanic stage composed of chambers in biloculine arrangement (Fig. 16B, O). The maximum diameter in axial section is around $2.75 \mathrm{~mm}$. The basal layer increases in thickness from the first to second biloculine chamber and can reach 3 or 4 times the height of the chamberlets and shows sporadically passages as in the megalospheric forms (Fig. 16B, D).
Age. The biostratigraphic range of Fabularia roselli extends from early Lutetian (SBZ13) to middle Lutetian 2 (SBZ15). The SBZ13 is characterized by the association with Alveolina obtusa (sample G 16; Fig. 3), A. stipes (samples G 19, G 21 and I 2; Figs. 3; 4), A. tenuis (sample I 7; Fig. 4) and Assilina spira abrardi (sample I 7; Fig. 4), indicating early Lutetian (Alveolina stipes and Assilina spira abrardi zones). The SBZ14 is characterized by the association of this species with Nummulites aspermontis, $N$. beneharnensis (sample I 8; Fig. 4), indicating middle Lutetian 1 (N. gratus-N. beneharnensis Zone). Finally, the 
SBZ15 is characterized by the association of this species with $N$. aff. deshayesi (sample P 17; Fig. 7), indicating middle Lutetian 2 (N. sordensis-N. crassus Zone).

Fabularia ovata DE ROISSY, 1805

Fig. 16P-Y

1964 Fabularia discolithes (Defrance). Hottinger et al., p. 642, 644; pl. 6, figs. 2a, 2b

1988 Fabularia ovata (de Roissy). Drobne, figs. $9.10-9.11$

Material. This species occurs in the Gabardiella, La Foz de Escalete, La Peña and Villalangua sections (Figs. $3 ; 6 ; 7 ; 9)$.

Description. The megalospheric forms show an ovoid morphology. The outline in axial section is elliptical to slightly depressed at the junction of the chambers (Fig. 16P, $\mathrm{S}-\mathrm{U})$. The embryonic apparatus is formed of a spherical proloculus with a diameter between $180-300 \mu \mathrm{m}$, followed by a flexostyle and chambers in biloculine arrangement (Fig. 16R). For 8 biloculine chambers, in axial section, the maximum elliptical diameter varies between $0.90 \mathrm{~mm}$ and $1.30 \mathrm{~mm}$ and the minimum between $675 \mu \mathrm{m}$ and $950 \mu \mathrm{m}$. The trematophore is supported by a short pillar (Fig. 16R). The basal layer is thin and the septula form chamberlets with a regular distribution (Fig. 16R, S). The chamberlets show a rectangular outline in axial section in the internal chambers, while it changes to a subrectangular shape with rounded base and a flat ceiling in the external chambers.

Remarks. This species differs from Fabularia roselli in the smaller size of the test, in displaying axial sections with an elliptical instead of a subcircular outline and in the tighter growth pattern of the chambers.

Age. The biostratigraphic range of Fabularia ovata extends from early Lutetian (SBZ13) to middle Lutetian 2 (SBZ15). The SBZ13 is characterized by the alternation of samples with this species with samples with A. stipes (Fig. 3), indicating early Lutetian (A. stipes Zone). In the material studied, no characteristic species of the SBZ14 (middle Lutetian 2) were found associated with Fabularia ovata. Finally, the SBZ15 is characterized by the alternation of samples with this species with samples containing $N$. crassus (Fig. 6) which indicate middle Lutetian 2 (N. sordensis-N. crassus Zone).

GENUS Pseudolacazina CAUS, 1979

Type species: Pseudolacazina hottingeri CAUS, 1979

Pseudolacazina hottingeri CAUS, 1979

Fig. 17A-R

1979 Pseudolacazina hottingeri n. gen. n. sp. Caus, p. 33 and 36; text-figs. 3-4; pl. 2 figs. 1-9; pl. 3 figs. 1-8
$2012 \mathrm{a}$

Pseudolacazina hottingeri Caus, 1979. Rodríguez-Pintó et al., on-line Supplementary Material, pl. 4, figs. 1-3; pl. 5, figs. 1-8; pl. 6, figs. 1-9

2013a Pseudolacazina hottingeri Caus, 1979. Rodríguez-Pintó et al., figs. 1-3

Material. This species occurs in the Gabardiella, Isuela, Sierra Caballera, La Foz de Escalete, La Peña, Murillo and Villalangua sections (Figs. 2-9).

Description. The megalospheric forms show an ovoidsubspherical morphology. The embryonic apparatus is formed of a subspherical proloculus with a diameter between $175-340 \mu \mathrm{m}$, followed by a flexostyle (Fig. 17M, P). The neanic stage is composed of chambers in biloculine arrangement. However, some specimens show a nepionic stage formed of chambers in triloculine arrangement following the flexostyle (Fig. 17J). The basal layer is thin without passages inside it. Four biloculine chambers measured in equatorial section were around $2.3 \mathrm{~mm}$ across, whereas in axial section they measured $1.8 \mathrm{~mm}$. In axial section, the septula subdivided the chamber in chamberlets, some septa do not reach the ceiling of the chamber (Fig. 17D, I, M). The apertural system is a trematophore supported by pillars and apertures in cribrate distribution (Fig. 17H). The microspheric forms show a subspherical morphology and maximum diameter of $4.2 \mathrm{~mm}$ (Fig. 17A).

Age. The biostratigraphic range of Pseudolacazina hottingeri extends from early Lutetian (SBZ13) to late Lutetian (SBZ16). The SBZ13 is characterized by the association of this species with Alveolina obtusa (samples G 16, I 1; Figs. 3; 4), A. callosa (samples SC 11 and SC 14; Fig. 5), and A. stipes (sample I 2; Fig. 4), indicating early Lutetian (A. stipes Zone). Samples belonging to the SBZ14 are characterized by the presence of $\mathrm{P}$. hottingeri in beds underlying samples with A. munieri, Nummulites aspermontis and N. beneharnensis (Fig. 4), indicating middle Lutetian 1 (A. munieri and N. gratus-N. beneharnensis zones). The SBZ15 is characterized by the association of $\mathrm{P}$. hottingeri with $N$. crassus (sample $\mathrm{E}$ 16; Fig. 6), indicating middle Lutetian 2 (N. sordensis-N. crassus Zone). Finally, the SBZ16 is characterized by the occurrence of $P$. hottingeri above samples with $N$. aturicus and $N$. deshayesi (Figs. 5; 8), indicating late Lutetian (N. aturicus Zone).

GENUS Periloculina MUNIER-CHALMAS AND
SCHLUMBERGER, 1885
Type species: Periloculina zitteli MUNIER-CHALMAS AND
SCHLUMBERGER, 1885

Periloculina cf. raincourti SCHLUMBERGER, 1905 Fig. 17S-X 


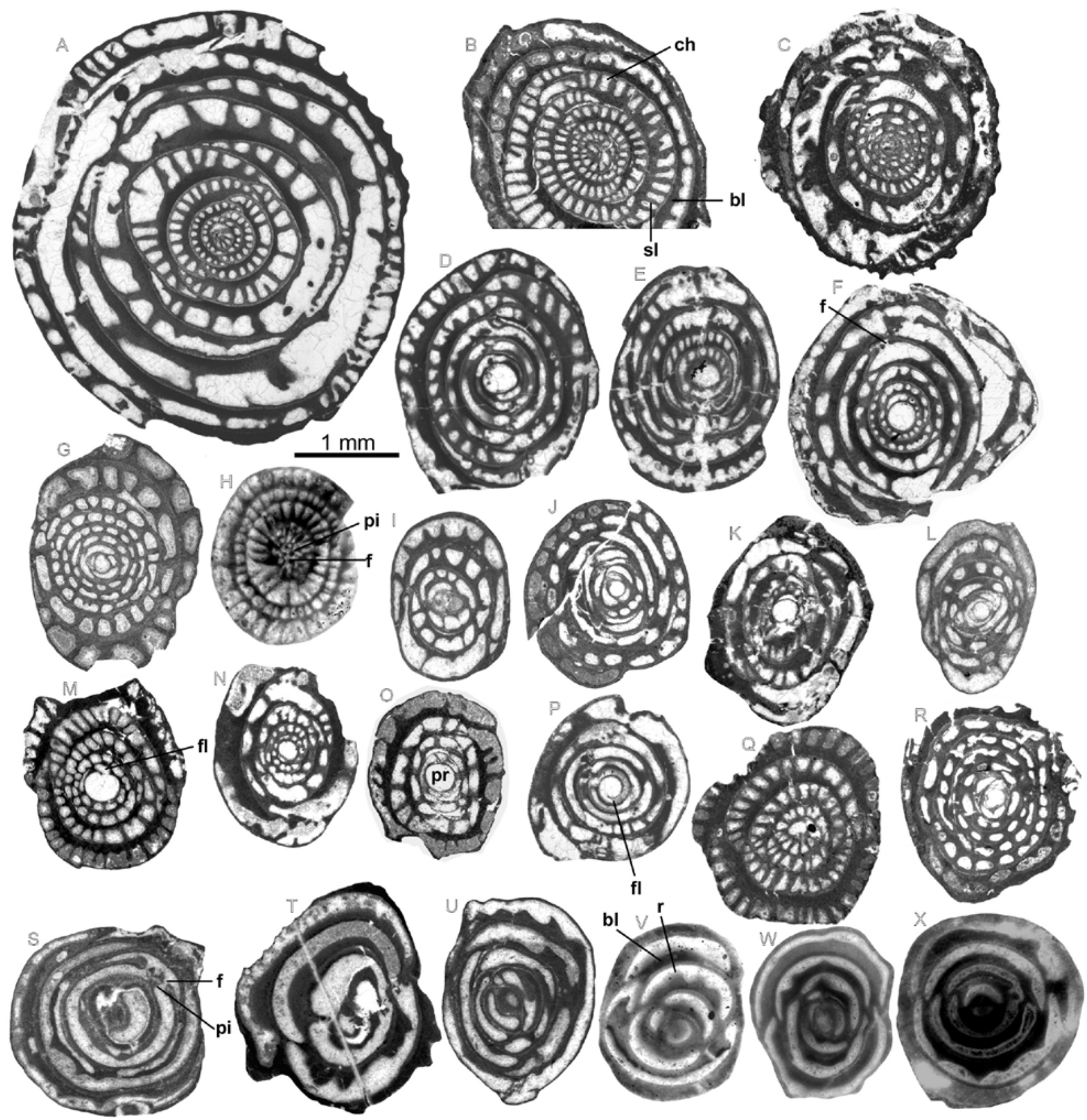

FIGURE 17. A-R) Pseudolacazina hottingeri. A, B: axial sections, microspheric forms. C: oblique section, microspheric form. D-R: megalospheric forms. D: centered axial section. E: oblique section. F, G: slightly oblique axial sections. H: subaxial section; note the foramens and pillars. I: slightly oblique and slightly uncentered axial section. J: oblique section. K: centered longitudinal section. L: slightly oblique axial section. M: centered axial section; note the flexostyle. N: centered longitudinal section. O: slightly oblique axial sections. P: centered longitudinal sections; note the flexostyle. Q-R: centered axial sections. Specimens A, D, E, F, K, P: sample G 18; B, M: sample G 14; C, Q: sample G 16; G: sample I 34; H: sample M 2; I, L: sample I 28; J: sample I 31; N: sample G 13; O: sample G 10 and R: sample I 30. S-X) Periloculina cf. raincourti. S: oblique longitudinal section; note the foramens and the pillar in the trematophore. T: uncentered axial section. U: oblique longitudinal section. V-X: uncentered axial sections; note the ribs in the basal layer. Specimens S, V: sample I 28; T: sample G 24; U: sample I 30; W: sample SC 22 and X: sample SC 23. Abbreviations: ch: chamberlet; bl: basal layer; fl: flexostyle; sl: septulum; f: foramen; pi: pillar; pr: proloculus; r: rib. 
Material. This species occurs in the Gabardiella, Isuela and La Foz de Escalete sections (Figs. 3; 4; 6).

Remarks. Only oblique sections were obtained in the material studied. Nonetheless, the basal layer with coarse ribs in irregular distribution and the biloculine growth pattern of the neanic stage justify its attribution to genus Periloculina (Fig. 17T-X). The lack of an axial centered section is the reason why this species is left in open nomenclature.

Age. The biostratigraphic range of Periloculina cf. raincourti extends from middle Lutetian 1 (SBZ14) to middle Lutetian 2 (SBZ15). The SBZ14 is characterized by the association of this species with Alveolina munieri (sample G 24; Fig. 3), indicating middle Lutetian 1 (A. munieri Zone). The SBZ15 is characterized by the stratigraphic location of $P$. cf. raincourti above beds with Nummulites crassus and N. aff. deshayesi (Fig. 6), indicating middle Lutetian 2 (N. sordensis-N. crassus Zone).

Family: Alveolinidae EHRENBERG, 1839

GENUS Alveolina D'ORBIGNY, 1826

Type species: Oryzaria boscii DEFRANCE IN BRONN, 1825

Alveolina ospiensis DROBNE, 1977

Fig. 18A-D

1977 Alveolina ospiensis n. sp. Drobne, p. 68-69; pl. 20, figs 8 and 9

Material. This species is present in the Gabardiella section (Fig. 3).

Description. Microspheric forms not found. The megalospheric forms are of large size, subcylindrical morphology and rounded poles. The axial length ranges from $17.3 \mathrm{~mm}$ to $23.3 \mathrm{~mm}$ and the equatorial diameter from $2.9 \mathrm{~mm}$ to $3.8 \mathrm{~mm}$ for 16 whorls. The index of elongation varies from 4.6 to 6.6. The proloculus shows a circular outline in axial section and its diameter varies from $420 \mu \mathrm{m}$ to $700 \mu \mathrm{m}$. The nepionic stage around the proloculus, formed of 4-5 whorls, produces a slight inflexion in axial section. The nepionic stage is formed of one tightly coiled whorl, followed by 10-12 elongated whorls with rounded poles in axial section. The axial elongation decreases in the last 4-5 whorls with truncated or rounded poles. At the polar zone there are abundant supplementary passages in the basal layer. In axial section the chamberlets are very small, tight, and frequent intercalary chamberlets occur in the outer whorls.

Remarks. As pointed out by Drobne (1977) this species is close to A. callosa and differs from it in its larger overall size, the larger diameter of the proloculus and the spiral more loosely coiled.
Age. According to Drobne in Serra-Kiel et al. (1998) the biostratigraphic range of this species is SBZ13-middle SBZ14. Here this species is associated with $A$. callosa (sample G 3; Fig. 3), indicating early Lutetian (A. stipes Zone) or SBZ13.

\section{Alveolina decastroi DI SCOTTO, 1966}

\section{Fig. 19A-D}

1966 Alveolina (Alveolina) decastroi n. sp. Di Scotto, p.69-70; tbl. 1, fig. 32; tbl. 2, fig. 1-6; tbl. 3, fig. 1- 4; text-fig. $1 \mathrm{~b}$

1977 Alveolina (Alveolina) decastroi Di Scotto. Drobne, p. 52; Pl. 11, fig. 5-8; text-figs. 29b, 45b

2013a Alveolina decastroi Di Scotto. 1966.

Rodríguez-Pintó et al., figs. 18-19

Material. This species is present in the Gabardiella section (Fig. 3).

Description. Microspheric forms not found. The megalospheric forms show an oval morphology with rounded poles. The axial length ranges from $2.0 \mathrm{~mm}$ to $2.3 \mathrm{~mm}$ and the equatorial diameter from $1.2 \mathrm{~mm}$ to $1.3 \mathrm{~mm}$ for 6 whorls. The index of elongation varies between 1.5-1.8. The proloculus is circular in axial section, with
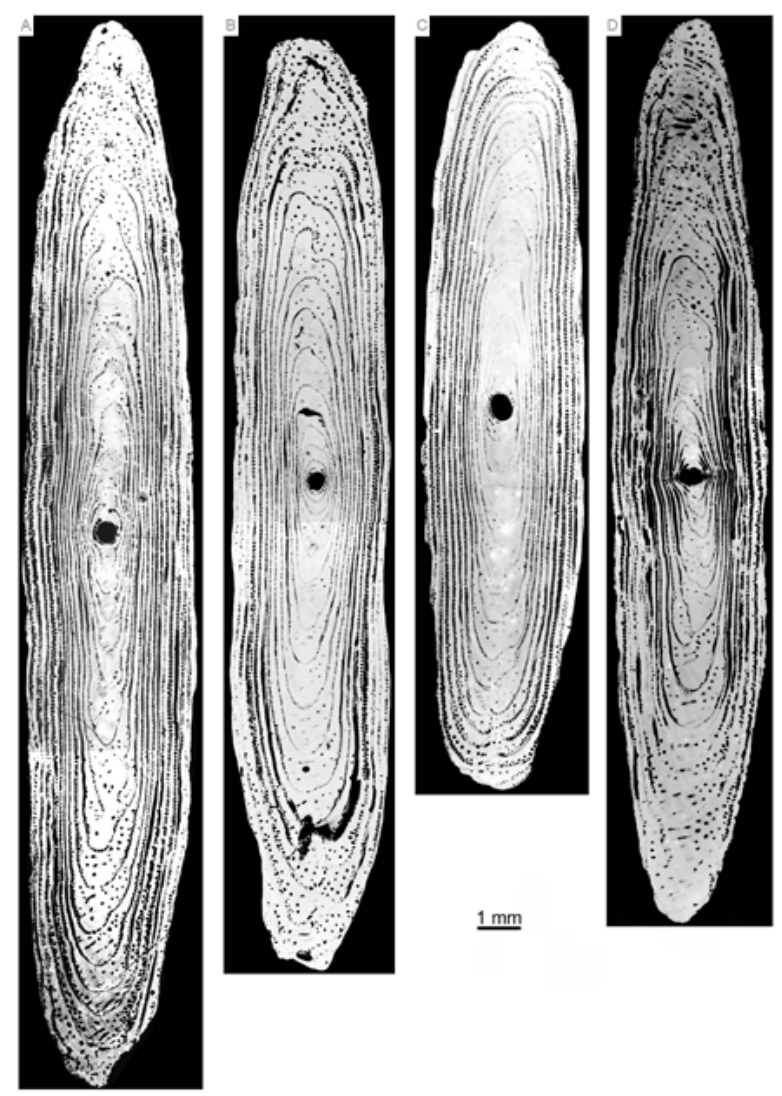

FIGURE 18. A-D) Alveolina ospiensis. Axial sections, megalospheric forms. All specimens from sample $\mathrm{G} 3$. 

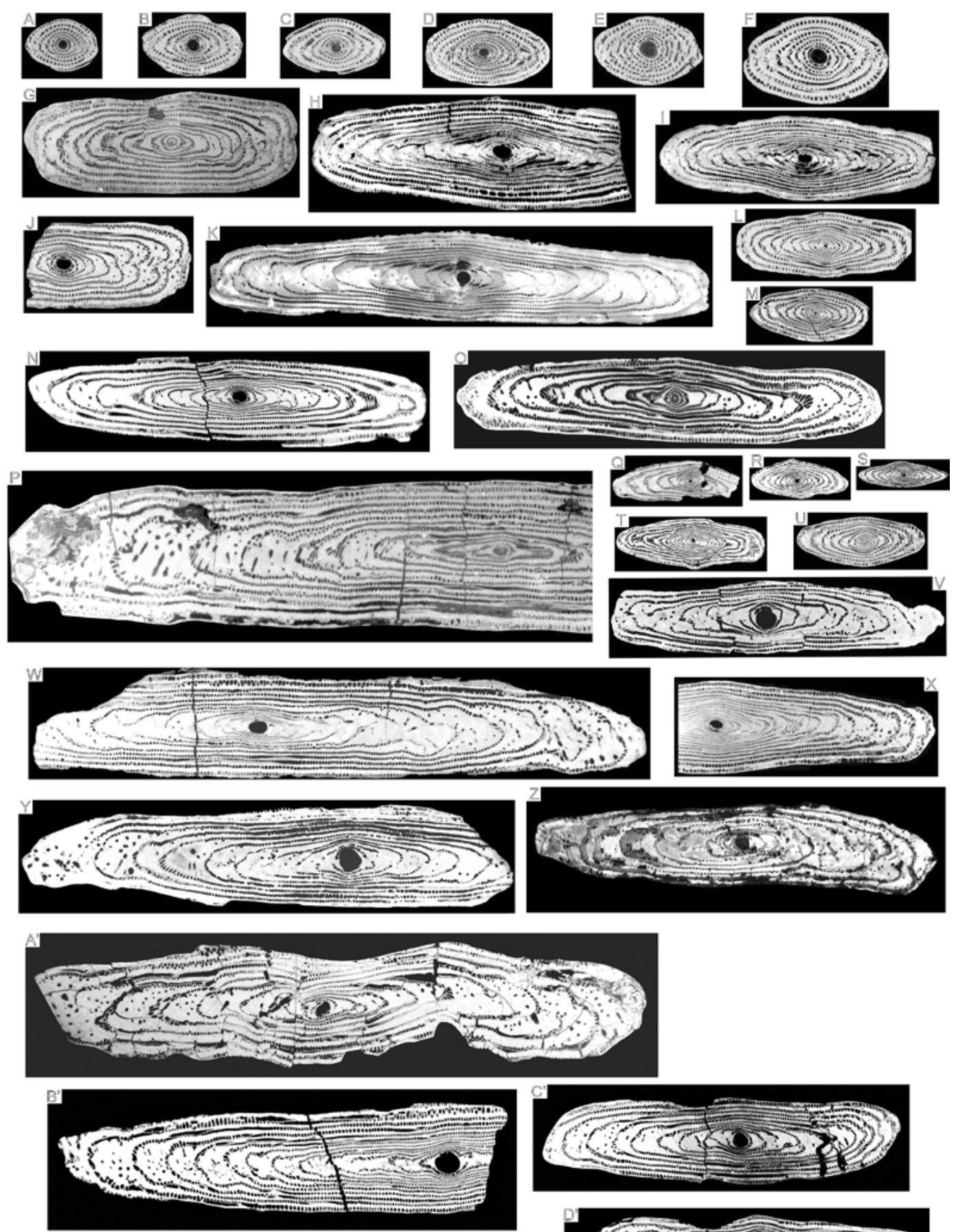

$\underline{1 \mathrm{~mm}}$



FIGURE 19. A-D) Alveolina decastroi axial sections, megalospheric forms. E-F) Alveolina cremae axial sections, megalospheric forms. G) Alveolina obtusa subaxial section, megalospheric form. H-I) Alveolina levantina axial sections, megalospheric forms. J) Alveolina obtusa axial section, megalospheric form. K) Alveolina tenuis axial section, megalospheric form. L-M) Alveolina boscii oblique axial sections; megalospheric forms. N-P) Alveolina tenuis. N-O: axial sections, megalospheric forms. P: axial section, microspheric form. Q-U) Alveolina boscii. Q: centered axial section. R: oblique axial sections. S: centered axial section. T: strongly oblique axial section. U: oblique axial section. All specimens megalospheric forms. V) Alveolina callosa axial section, megalospheric form. W) Alveolina stipes axial sections, megalospheric forms. X) Alveolina tenuis axial section, megalospheric form. Y-Z) Alveolina callosa axial section, megalospheric form. A'-D') Alveolina munieri axial sections, megalospheric forms. A-F: sample G 1; G: sample G 16; H-I: sample I 7; J: sample G 16; K: sample I 7; L: G 15; M, Q: sample G 18; N: sample I 7; O: sample G 21; P: sample G 17; R, U: sample G 16; S: sample G 14; T: sample G 34; X: sample I 13; W: sample G 4; V, Y: sample G 3 and Z: sample SC 12; A': sample I 17; B', D': sample I 20 and C': sample I 16 
a diameter ranging between $190 \mu \mathrm{m}$ and $275 \mu \mathrm{m}$. The nepionic stage is formed of 2-3 tightly coiled whorls followed by chambers with a moderate elongation in axial section. The chamberlets have a circular outline in the inner whorls and a subrectangular outline in the outer whorls. The equatorial spiral is tightly coiled and the basal layer is thin, except in the outer whorls where it reaches the height of the chamberlets.

Age. The biostratigraphic range of $A$. decastroi is middle Cuisian (SBZ11). This species occurs in the Boltaña Fm. (sample G 1; Fig. 3) associated with A. cremae, indicating middle Cuisian (A. dainelli Zone) or SBZ11.

\section{Alveolina cremae CHECCHIA-RISPOLI, 1905}

\section{Fig. 19E-F}

$1960 \quad$ Alveolina cremae Checchia-Rispoli, 1905. Hottinger, p. 152-1 54; pl. 10, fig. 8- 10; pl. 11, fig. 4- 8; pl. 14, fig. 8; text- fig $21 \mathrm{~g}$

1966 Alveolina (Alveolina) cremae ChecchiaRispoli. Di Scotto, p.71-72; tbl. 7, fig. 2-6; tbl. 8, fig. 14; tbl.9, fig. 1-6; tbl. 10, fig. 4-5; tbl. 11, fig. 5- 6; tbl. 12, fig. 4- 6, text-fig. $1 \mathrm{~d}$

1977 Alveolina cremae Checchia-Rispoli. Drobne, p. 55-56; pl. 12, fig. 15-17, 18-20; pl. 13, fig. 1-5; text-fig. $30 \mathrm{a}-\mathrm{c}$

2013 ${ }^{\mathrm{a}}$ Alveolina cremae CHECCHIA-RISPOLI. 1905. Rodríguez-Pintó et al., figs. 23-14

Material. This species is present in the Gabardiella section (Fig. 3).

Description. Microspheric forms not found. The megalospheric forms show an oval to fusiform morphology with rounded poles in axial section. The axial length is $3 \mathrm{~mm}$ and the equatorial diameter is $1.9 \mathrm{~mm}$ for 8 whorls. The index of elongation is 1.6. The proloculus is subcircular in axial section, with a diameter of $375-410 \mu \mathrm{m}$. The nepionic stage around the proloculus is formed of 3-4 tight whorls, followed by 4-5 slightly elongated whorls in axial section, and rounded poles. The chamberlets have a circular outline in the inner whorls and an oval-subrectangular outline in the outer whorls. The equatorial spiral is tightly coiled and the basal layer is thin.

Age. According to the data available the biostratigraphic range of $A$. cremae is middle Cuisian (SBZ11). This species occurs in the Boltaña Fm. (sample G 1; Fig. 3) associated with $A$. decastroi, indicating middle Cuisian (A. dainelli Zone) or SBZ11.

\section{Alveolina obtusa MONTANARI, 1964}

\section{Fig. 19G, J}

1964 Alveolina obtusa n. sp. Montanari, p. 547-551; pl. 42 , figs. $1-5,8$
1977 Alveolina (Alveolina) obtusa Montanari. Drobne, p. 67, pl. 19, figs. 5-8; text fig. 37

$2012 \mathrm{a}$ Alveolina obtusa Montanari, 1964.

Rodríguez-Pintó et al., on-line Supplementary Material, pl. 10, figs. 1-6

Material. This species is present in the Gabardiella and Isuela sections (Figs. 3; 4).

Description. Microspheric forms not found. The megalospheric forms show a cylindrical morphology with truncated poles. The axial length ranges from $5.5 \mathrm{~mm}$ to $5.7 \mathrm{~mm}$ and the equatorial diameter from $1.9 \mathrm{~mm}$ to $2.1 \mathrm{~mm}$ for 9-10 whorls. The index of elongation varies between 2.7-2.9. The proloculus shows an elongated outline in axial section, and a diameter ranging between $240-370 \mu \mathrm{m}$. The nepionic stage is formed of two tightly coiled whorls followed, in axial section, by two elongated whorls with pointed poles and 7-8 whorls with truncated poles. At the polar area, the basal layer shows abundant supplementary passages. The chamberlets have a circular outline in the inner whorls and a subrectangular outline in the in external whorls. The basal layer is thin, except in the external whorl where it can reach the height of the chamberlets.

Age. The biostratigraphic range of $A$. obtusa is early Lutetian (SBZ13). The stratigraphic record of SBZ13 is characterized by the alternation of samples containing this species with samples containing A. stipes (Fig. 3), indicating early Lutetian (A. stipes Zone).

\section{Alveolina levantina HOTTINGER, 1960}

Fig. 19H-I

1960 Alveolina levantina n. sp. Hottinger, p. 154; pl. 10, figs. 11, 13; pl. 13, figs. 10, 11; pl. 14, figs. 5, 7, text fig. 84

1974 Alveolina levantina Hottinger. Hottinger, p. 47; pls. $49-51$

1977 Alveolina (Alveolina) levantina Hottinger. Drobne, p. 57; text figs. 31a, 32a, 46 a-d; pl. 14, figs. 1-6; pl. 15 , figs. 1,2

1977 Alveolina (Alveolina) levantina Hottinger. Drobne et al., p. 74; pl. 4, fig. 5

2007 Alveolina levantina Hottinger. Vecchio et al., p. $34-35$; pl. 2, figs. 18,19

2012a Alveolina levantina Hottinger, 1960. Rodríguez-Pintó et al., on-line Supplementary Material, pl. 12, figs. 1-3

Material. This species is present in the Isuela section (Fig. 4).

Description. Microspheric forms not found. Megalospheric forms are fusiform, with pointed or slightly rounded poles. The axial length ranges from $5.6 \mathrm{~mm}$ to 
$8.2 \mathrm{~mm}$ and the equatorial diameter from $1.7 \mathrm{~mm}$ to $2.0 \mathrm{~mm}$ for 12 whorls. The index of elongation varies from 3.2 to 4. The proloculus is circular or oval in axial section and the diameter varies from $310 \mu \mathrm{m}$ to $580 \mu \mathrm{m}$. The nepionic stage around the proloculus is formed of 1 or 2 tightly coiled whorls, followed by 9-11 whorls with axial elongation and rounded or slightly pointed poles. The chamberlets have a circular outline in the inner whorls, and are oval or subrectangular in the outer whorls. The equatorial spiral is tightly coiled and the basal layer is thin. Some specimens exhibit intercalary chamberlets and secondary passages in the basal layer at the polar zone (Fig. 19H-I).

Age. This species has different biostratigraphic attributions. According to Hottinger (1960) its age is probably early Lutetian. Hovewer, Hottinger (1974) and Hottinger and Drobne (1988) attributed this species to middle Cuisian-late Cuisian (see fig. 2, op . cit., Hottinger and Drobne (1988)) but in the figures this species appears as a typical species of the early Lutetian (see pl. IV, op. cit., Hottinger and Drobne (1988)). Finally, Serra-Kiel et al. (1998) constrained the age of this species from the middle part of middle Cuisian (middle part SBZ11) to late Cuisian (SBZ12). Summarizing, the biostratigraphic range of this species is from the middle part of middle Cuisian to early Lutetian (middle part SBZ11-SBZ13). In the samples studied this species is associated with Alveolina stipes and Assilina spira abrardi (sample I 7; Fig. 4), indicating early Lutetian (A. stipes Zone) or SBZ13.

\section{Alveolina boscii (DEFRANCE IN BRONN, 1825) \\ Fig. 19L-M, Q-U}

1960 Alveolina boscii (DEFRANCE IN BRONN). Hottinger, p. 149; pl. 10, figs. 19-22; text figs. 78, 79

1964 Alveolina boscii (DEFRANCE). Hottinger et al., p. $638 ;$ pl. 3

1974 Alveolina boscii (DEFRANCE IN BRONN). Hottinger, p. 63; pl. 87

Material. This species is present in the Gabardiella section (Fig. 3).

Description. Microspheric forms not found. Megalospheric forms are of small size, and show an oval to fusiform morphology with rounded or slightly pointed poles in axial section. The axial length ranges from $1.6 \mathrm{~mm}$ to $2.0 \mathrm{~mm}$ and the equatorial diameter from $0.6 \mathrm{~mm}$ to $0.8 \mathrm{~mm}$ for 8 whorls, with an index of elongation of 2.4-3.3. For 9 whorls the axial length varies between $2.6-3.4 \mathrm{~mm}$ and the equatorial diameter between $0.7-1.2 \mathrm{~mm}$, with an index of elongation of 2.6-3.7. The diameter of the proloculus is small, $75-80 \mu \mathrm{m}$. The nepionic stage is formed of $4-5$ tightly coiled whorls followed by chambers with a moderate elongation in axial section. The chamberlets have a circular outline in the inner whorls and are subrectangular in the outer whorls. The equatorial spiral is tightly coiled and the basal layer is thin.

Age. The biostratigraphic range of $A$. boscii extends from early Lutetian (SBZ13) to middle Lutetian 1 (SBZ14). The SBZ13 is characterized by the association of this species with A. obtusa and A. stipes (samples G 16, G 21; Fig. 3) (early Lutetian, A. stipes Zone). The SBZ14 is characterized by the stratigraphic location of $A$. boscii overlying beds with A. munieri (Fig. 3), indicating middle Lutetian 1 (A. munieri Zone).

\section{Alveolina tenuis HOTTINGER, 1960}

Fig. 19K, N-P, X

1960 Alveolina tenuis n. sp. Hottinger, p. 164; pl. 16, fig. 22; pl. 18, figs. 5-9, 17; text figs. 87, 90

1965 Alveolina tenuis Hottinger. Dizer, p. 276; pl. 3, figs. 11-13; pl. 4, figs. 9-12; text fig. 5

1974 Alveolina tenuis Hottinger. Hottinger, p. 45; pl. 44, figs. $1-7$

1977 Alveolina (Alveolina) tenuis Hottinger. Drobne, 70; pl. 21, figs. 6-8

2008 Alveolina tenuis Hottinger. Sirel and Acar, p. 83; pl. 75 , figs. $1-4$

2012a Alveolina tenuis Hottinger, 1960. Rodríguez-Pintó et al., on-line Supplementary Material, pl. 10, figs. 12-15.

2013a Alveolina tenuis Hottinger, 1960. Rodríguez-Pintó et al., fig. 17

Material. This species is present in the Gabardiella, Isuela and Sierra Caballera sections (Figs. 3; 4; 5).

Description. Microspheric forms show a cylindrical morphology with rounded poles. At the polar zones there are abundant and large supplementary passages in axial section. The axial length is $10.8 \mathrm{~mm}$ and the equatorial diameter is $3.3 \mathrm{~mm}$ for $14-15$ whorls. The megalospheric forms show a subcylindrical morphology and rounded poles. The axial length ranges from $9.2 \mathrm{~mm}$ to $10.3 \mathrm{~mm}$ and the equatorial diameter from $1.7 \mathrm{~mm}$ to $1.9 \mathrm{~mm}$ for $10-11$ whorls. The index of elongation varies from 4.7 to 5.4 . The proloculus is circular or slightly elongated in axial section and the diameter varies from $320 \mu \mathrm{m}$ to $340 \mu \mathrm{m}$. The nepionic stage is formed of one tightly coiled whorl, followed by 2-3 whorls with moderate axial elongation and pointed poles. The neanic stage is formed of 7-10 whorls with strong axial elongation and rounded poles. At the polar zone there are abundant supplementary passages in the basal layer. The chamberlets are small, very numerous and, in axial section, show a circular outline in the inner whorls, and an oval to subrectangular outline in the outer whorls. The equatorial spiral is tightly coiled and the basal layer is thin. 
Age. This species was found associated with Alveolina stipes and Assilina spira abrardi (sample I 7; Fig. 4), indicating early Lutetian (A. stipes and A. spira abrardi zones) or SBZ13. A tenuis occurs interbedded with samples containing Nummulites aspermontis and $N$. beneharnensis (Fig. 4), which indicate middle Lutetian 1 (N. gratus-N. beneharnensis Zone) or SBZ14. Thus, according to the stratigraphic location of Alveolina tenuis (Figs. 3-5) we confirm the biostratigraphic range proposed for this species by Drobne in Serra-Kiel et al. (1998), from the middle of SBZ13 to the middle of SBZ14.

\section{Alveolina callosa HOTTINGER, 1960}

Fig. 19V, Y-Z

1960 Alveolina callosa n. sp. Hottinger, p. 160; pl. 14, figs. 18, 19; pl. 15, figs. 7-10; text fig. 84

1964 Alveolina callosa Hottinger. Montanari, p. 547; pl. 62, figs. $1-5,8$

1974 Alveolina callosa Hottinger. Hottinger, p. 43; pl. 39

1977 Alveolina (Alveolina) callosa Hottinger. Drobne, p. 68; pl. 20, figs. 1-5

2008 Alveolina callosa Hottinger. Sirel and Acar, p. 82; pl. 75, figs. 7-8

2012a

Alveolina callosa Hottinger, 1960.

Rodríguez-Pintó et al., on-line Supplementary Material, pl. 10, fig. 16; pl. 11, figs. 1-4

Material. This species is present in the Gabardiella and Sierra Caballera sections (Figs. 3; 5).

Description. Microspheric forms not found. The megalospheric forms show subcylindrical morphology and rounded poles. For 9 whorls the axial length is $7.8 \mathrm{~mm}$ and the equatorial diameter is $1.7 \mathrm{~mm}$. The index of elongation is 4.5 . The proloculus shows a circular outline in axial section and the diameter varies from $290 \mu \mathrm{m}$ to $310 \mu \mathrm{m}$. The nepionic stage is formed of one tightly coiled whorl, followed by 8-9 whorls with axial elongation and pointed poles. At the polar zone there are abundant large supplementary passages in the basal layer. In axial section, the chamberlets show a circular outline in the inner whorls, and an oval to subrectangular outline in the outer whorls. The basal layer can reach the height of the chamberlets in equatorial section.

Age. In the material studied $A$. callos $a$ occurs along with $A$. tenuis in beds below samples with Nummulites lehneri and Assilina spira abrardi (Fig. 5), indicating early Lutetian (N. laevigatus-N. obesus and A. spira abrardi zones) or SBZ13.

\footnotetext{
Alveolina stipes HOTTINGER, 1960

Fig. 19W

1960 Alveolina stipes n. sp. Hottinger, p. 163; pl. 16,
}

figs. 8 , 9; pl. 17, figs. 5-10; pl. 18, fig. 16; text figs. 86-88 1964 Alveolina stipes Hottinger. Hottinger et al., p. $638 ;$ pl. 3

1974 Alveolina stipes Hottinger. Hottinger, p. 44-45; pl. 43. Figs. 1-6

1977 Alveolina (Alveolina) stipes Hottinger. Drobne, p. 69 ; pl. 21, figs. 2-4

1977 Alveolina (Alveolina) stipes Hottinger. Drobne et al., p. 77; pl. 6, figs. 1-2

2007 Alveolina stipes Hottinger. Vecchio et al., p. 35; pl. 3, figs. 1-10

2008 Alveolina stipes Hottinger. Sirel and Acar, p. 81; pl. 75, figs. 9-11

2012a Alveolina stipes Hottinger, 1960. Rodríguez-Pintó et al., on-line Supplementary Material, pl. 10, figs. 17-21

Material. This species is present in the Gabardiella and Isuela sections (Figs. 3; 4).

Description. Microspheric forms not found. The megalospheric forms show a fusiform to subcylindrical morphology, slightly inflated around the first whorls in axial section, and rounded or slightly truncated poles. For 10 whorls the axial length ranges from $12 \mathrm{~mm}$ to $14.6 \mathrm{~mm}$ and the equatorial diameter from $1.6 \mathrm{~mm}$ to $2 \mathrm{~mm}$. The index of elongation varies from 6.0 to 8.6. The proloculus shows a circular or slightly elongated outline in axial section and a diameter of $390 \mu \mathrm{m}$ to $500 \mu \mathrm{m}$. The nepionic stage is formed of one tightly coiled whorl. The neanic stage is formed of whorls with axial elongation and abundant supplementary passages in the basal layer at the polar zones. The equatorial spiral is tightly coiled and the basal layer is thin. The chamberlets exhibit a circular axial section in the inner whorls whereas they are oval to subrectangular in the external whorls.

Age. This species was considered a biomarker of the early Lutetian (A. stipes Zone) by Hottinger (1960, 1974) and Hottinger and Drobne (1988). In the material studied, A. stipes occurs along with Assilina spira abrardi (sample I 7; Fig. 4), indicating early Lutetian (A. spira abrardi Zone) or SBZ13.

\section{Alveolina munieri HOTTINGER, 1960}

Fig. 19A'-D'

1960 Alveolina munieri n. sp. Hottinger, p. 165; pl. 16, figs. $16-21$; pl. 17 , figs. $1-4$; pl. 18 , figs. $1-4$, 18 ; text figs. 86-88, 91

1974 Alveolina munieri Hottinger. Hottinger, p. 45; pl. 44, figs. 1-7

1977 Alveolina (Alveolina) munieri Hottinger. Drobne, p. 69; pl. 21, fig. 5

2012a Alveolina munieri Hottinger, 1960. Rodríguez-Pintó et al., on-line Supplementary Material, pl. 10, figs. 16-20 
Material. This species is present in the Gabardiella and Isuela sections (Figs. 3; 4).

Description. Megalospheric forms show a cylindrical morphology and rounded poles. For 12 whorls the axial length is $8 \mathrm{~mm}$ and the equatorial diameter is $2.36 \mathrm{~mm}$. The index of elongation is 6.7. The proloculus shows a circular outline in axial section and a diameter of $300-570 \mu \mathrm{m}$. The nepionic stage is formed of one tightly coiled whorl around the proloculus, followed by whorls with axial elongation. There are abundant supplementary passages located at the polar zone and intercalated chamberlets in the more external whorls. The thickness of the basal layer increases progressively from the proloculus towards the outside of the test in the equatorial section. The chamberlets exhibit a circular axial section in the inner whorls and an oval to subrectangular axial section in the external whorls.

Age. This species was considered a biomarker for the middle Lutetian 1 (A. munieri Zone) by Hottinger (1960, 1974) and Hottinger and Drobne (1988). In the sections studied, beds with $A$. munieri alternate with beds containing Nummulites aspermontis and $N$. beneharnensis (Fig. 4), which indicates middle Lutetian 1 (N. gratus-N. beneharnensis Zone) or SBZ14.

\section{Alveolina fusiformis SOWERBY IN DIXON, 1850 Fig. 20A-L \\ 1960 Alveolina fusiformis Sowerby in Dixon.} Hottinger, p. 169-170; pl. 12 figs.5-7, pl. 14 figs. 1-4; pl. 17 fig. 17; pl. 18, fig. 11; text-figures 92, 94

1962 Alveolina fusiformis Sowerby. Adams, p. 48; pl. 1 figs. 1-5; pl. 2, figs. 1-12; pl. 3, figs. 1-8

1965 Alveolina fusiformis Sowerby. Dizer, p. 278; pl. 4, figs. $1-8$, text fig. 5

1974 Alveolina fusiformis Sowerby in Dixon.

Hottinger, p. 47, 50; pl. 52

2008 Alveolina fusiformis Sowerby. Sirel and Acar, p. 84; pl. 76, figs. 2-5

2012 alveolina fusiformis Sowerby. Rodríguez-Pintó et al., on-line Supplementary Material, pl. 12, figs. 9-12

Material. This species is present in the Gabardiella, Isuela, Sierra Caballera, La Foz de Escalete, La Peña, Murillo, Villalangua, San Felices and La Osqueta sections (Figs. 3-11).

Description. Microspheric forms not found. Megalospheric forms show a fusiform to subcylindrical morphology with frequents irregularities in the surface and rounded poles. The axial length at the $8^{\text {th }}, 10^{\text {th }}$ and $12^{\text {th }}$ whorls measures $3.9-7.2 \mathrm{~mm}, 5.0-7.4 \mathrm{~mm}$ and $6.8-8.8 \mathrm{~mm}$ respectively, and the equatorial diameter $0.77-1.22 \mathrm{~mm}$, $1.0-1.36 \mathrm{~mm}$ and $1.3-1.7 \mathrm{~mm}$ respectively. The index of elongation varies from 4.5 to 6.8 . The proloculus displays circular or elongated axial outline and a length of 220$470 \mu \mathrm{m}$. The nepionic stage is formed of one tightly coiled whorl followed by chambers with axial elongation. The basal layer is thin in equatorial section, and in axial section its thickness increases gradually from the $2^{\text {nd }}$ whorl to the external whorls. There are rare chamberlets intercalated in the external whorls and frequent supplementary passages at the polar area.

Remarks. Alveolina fusiformis from the "Biarritzian" of Grotte de Brassempouy and Lasserre in Aquitaine, France (Hottinger 1974: pl. 52, figs 2, 6; Fig. 20H-L) displays a much larger morphological variability than the material studied here (Fig. 20A-G).

Age. Dizer (1965) found this species associated with Nummulites aturicus JOLY AND LEYMERIE, 1848 (Karasivri, Haymana Basin, Turkey, p. 278 op. cit.), indicating a late Lutetian age. On the other hand, Hottinger $(1960,1974)$ considered A. fusiformis to be "Biarritzian" in age, and Sirel and Acar (2008) Bartonian, unfortunately these data was not supported by other larger foraminifera, such as Nummulites. In the material studied the association of $A$. fusiformis with $A$. munieri (samples I 20; see Fig. 4) indicates middle Lutetian 1 (A. munieri Zone) or SBZ14. The alternation of beds with $A$. fusiformis with beds containing $N$. crassus and $N$. aff. deshayesi (Fig. 5) indicates middle Lutetian 2 (N. sordensis-N. crassus Zone) or SBZ15. Finally, the alternation of beds with A. fusiformis with samples with $N$. aturicus and $N$. deshayesi (Fig. 5) indicate late Lutetian (N. herbi-N. aturicus Zone) or SBZ16. The entire dataset determines that the biostratigraphic range of Alveolina fusiformis spans from middle Lutetian 1 or SBZ14 to late Lutetian or SBZ16 and probably up to early Bartonian or SBZ17.

\section{Alveolina aff. fragilis HOTTINGER, 1960 Fig. 20M-P}

Material. This species is present in the $\mathrm{La} \mathrm{Foz} \mathrm{de}$ Escalete, La Peña, Murillo, Villalangua, San Felices and La Osqueta sections (Figs. 6-11).

Description. Microspheric forms not found. Megalospheric forms show a cylindrical morphology with rounded poles. The axial length ranges from $8 \mathrm{~mm}$ to $10.4 \mathrm{~mm}$ and the equatorial diameter from $1 \mathrm{~mm}$ to $1.5 \mathrm{~mm}$ for 9-10 whorls. The index of elongation varies between 5.3 and 7.2. The proloculus shows an elongated outline in axial section with a diameter between $400-420 \mu \mathrm{m}$. The equatorial section is very tightly coiled. The basal layer is thin in equatorial section and its thickness increases in axial section. 



FIGURE 20. A-L) Alveolina fusiformis axial sections, megalospheric forms. Specimens A, E: sample I 20; B: sample O 7; C, F: sample I 22; D: sample 03 and G: sample P 12. H, K, L: specimens from Lassere, Bastennes (Hottinger, 1974). I-J: specimens from Grotte de Brassempouy, Bastennes (Hottinger, 1974). M-P) Alveolina aff. fragilis axial sections, megalospheric forms. Specimen M: sample E 52; O: sample SF 6; N: sample P 32; P: sample E 15. Q-T) Alveolina aff. elongata axial sections, megalospheric forms. Specimen Q: sample SC 53; R: sample SF 6; S: sample V 10 and T: sample 03.

Remarks. $A$. aff. fragilis is considered here to be ancestor of $A$. fragilis because of the smaller dimensions of the test and proloculus.

Age. The biostratigraphic range of $A$. aff. fragilis extends from middle Lutetian 2 (SBZ15) to late Lutetian (SBZ16). The SBZ15 is characterized by the association of this species with $N$. crassus (sample E 16; Fig. 6), indicating middle Lutetian 2 (N. sordensis-N. crassus
Zone). The SBZ16 shows A. aff. fragilis interbeded with beds containing $N$. deshayesi (Fig. 7).

Alveolina aff. elongata D'ORBIGNY IN DESHAYES, 1828 Fig. 20Q-T

Material. This species is present in the Sierra Caballera, La Foz de Escalete, La Peña, Murillo, Villalangua, San Felices and La Osqueta sections (Figs. 5-11). 
Description. Microspheric forms not found. The megalospheric forms show an elongated fusiform morphology, rough in the external whorls, and pointed poles. The axial length ranges from $6.2 \mathrm{~mm}$ to $10.8 \mathrm{~mm}$ and the equatorial diameter from $0.9 \mathrm{~mm}$ to $1.6 \mathrm{~mm}$ for $8-10$ whorls. The index of elongation varies between 5.6 and 6.9. The proloculus shows a circular or slightly oval outline in axial section with a diameter of $350-410 \mu \mathrm{m}$. The nepionic stage is formed of one tightly coiled whorl followed by chambers with axial elongation and truncated poles. At the polar area, the basal layer shows abundant supplementary passages. The test is tightly coiled in equatorial section. The thickness of the basal layer is irregular, except in the equatorial section, where it reaches the height of chamberlets.

Remarks. This species is considered here to be the ancestral chronoespecies of $A$. elongata because of its smaller size. $A$. aff. elongata differs from $A$. aff. fragilis in the outline of the proloculus, which is circular to slightly elongate in the former and elongated in the latter. Moreover, $A$. aff. elongata shows a rougher surface and more supplementary passages at the polar zone.

Age. The biostratigraphic range of $A$. aff. elongata extends from middle Lutetian 2 (SBZ15) to late Lutetian (SBZ16). The stratigraphic record of SBZ15 is characterized by the alternation of $A$. aff. elongata beds with beds containing $N$. crassus (Figs. 6; 7), which indicates middle Lutetian 2 (N. sordensis-N. crassus Zone). The stratigraphic record of SBZ16 is characterized by the occurrence of $A$. aff. elongata beds overlying beds with $N$. aturicus and $N$. deshayesi (Fig. 5), indicating late Lutetian (N. herbi-N. aturicus Zone).

Family: Peneroplidae SCHULTZE, 1854

GENUS Spirolina LAMARCK, 1804

Type species: Spirolina cylindracea LAMARCK, 1804

Spirolina austriaca D’ORBIGNY, 1846

Fig. 21A-B

1963 Spirolina austriaca D’Orbigny. Hottinger, p. 966; pl. 3, figs. 1-2; text-figs. $2 \mathrm{~m}$, r

Material. This species is present in the Gabardiella and Isuela sections (Figs. 3; 4).

Remarks. Small shell, with a maximum length of $0.9 \mathrm{~mm}$. The first $17-18$ chambers display a planispiral arrangement, followed by an uniserial pattern. The uniserial length for 5 chambers is $0.4-0.6 \mathrm{~mm}$. Proloculus small, $20 \mu \mathrm{m}$ in diameter.

Age. This species has not biostratigraphical significance. It is found in the Guara Formation, where it is abundant in facies attributed to seagrass environments rich in porcellanous foraminifera (Silva-Casal, 2017).

GENUS Sivasina SIREL AND ÖZGEN-ERDEM, 2013

Type species: Sivasina egribucakensis SIREL AND ÖZGEN-ERDEM, 2013 2013

Sivasina egribucakensis SIREL AND ÖZGEN-ERDEM, Fig. 21C

1963 Peneroplis cf. elegans D’Orbigny. Hottinger, p. 969; pl. 5, figs. 3-5

1963 Peneroplis cf. farensis Henson. Hottinger, p. 969; pl. 5, figs. 6, 7; Fig. 2a, b

1963 Peneroplis aff. honestus Tood and Post. Hottinger, p. 969; pl. 5, fig. 9

2013 Sivasina egribucakensis n. gen. n. sp. Sirel et al., p. 96, 99; pl.46, figs. 1-14; pl. 5, figs. 1-10; pl. 6, figs. 1-6; Figs. 6G, $\mathrm{H}$

2016 Sivasina egribucakensis. Sirel and ÖzgenErdem, Serra-Kiel et al., p. 24; figs. 19.22-19.30

Material. This species is present in the Gabardiella section (sample G 27, Fig. 3). One specimen.

Description. The specimen shows a nepionic stage formed of chambers in planispiral-involute arrangement with the apertures located at the base of the chambers. The neanic stage dispalys uncoiled growth and dendritine aperture. The septa are inclined and slightly arcuate.

Age. Sirel et al. (2013) and Serra-Kiel et al. (2016) located this species in Rupelian (Oligocene) rocks from Slovenia and Socotra Island (Yemen) respectively. Here, S. egribucakensis occurs between samples with Alveolina munieri, indicating middle Lutetian 1 (A. munieri Zone) or SBZ14. Thus, its biostratigraphical range extends from middle Lutetian 1 or SBZ14 to Rupelian.

GENUS Penarchaias HOTTINGER, 2007

Type species: Peneroplis glynnjonesi HENSON, 1950

\section{Penarchaias sp.}

Fig. 21D-G

Material. This species is present in the Gabardiella section (Fig. 3).

Description. The test of the megalospheric forms is planispiral-involute, with an equatorial diameter of about $0.9-1.0 \mathrm{~mm}$ for 5 whorls with 50 chambers. The nepionic stage is formed of a spherical proloculus with a diameter of $c a$. $130 \mu \mathrm{m}$ and a flexostyle. The chambers with inclined septula present low ridges at the base (Fig. 21D, F). 


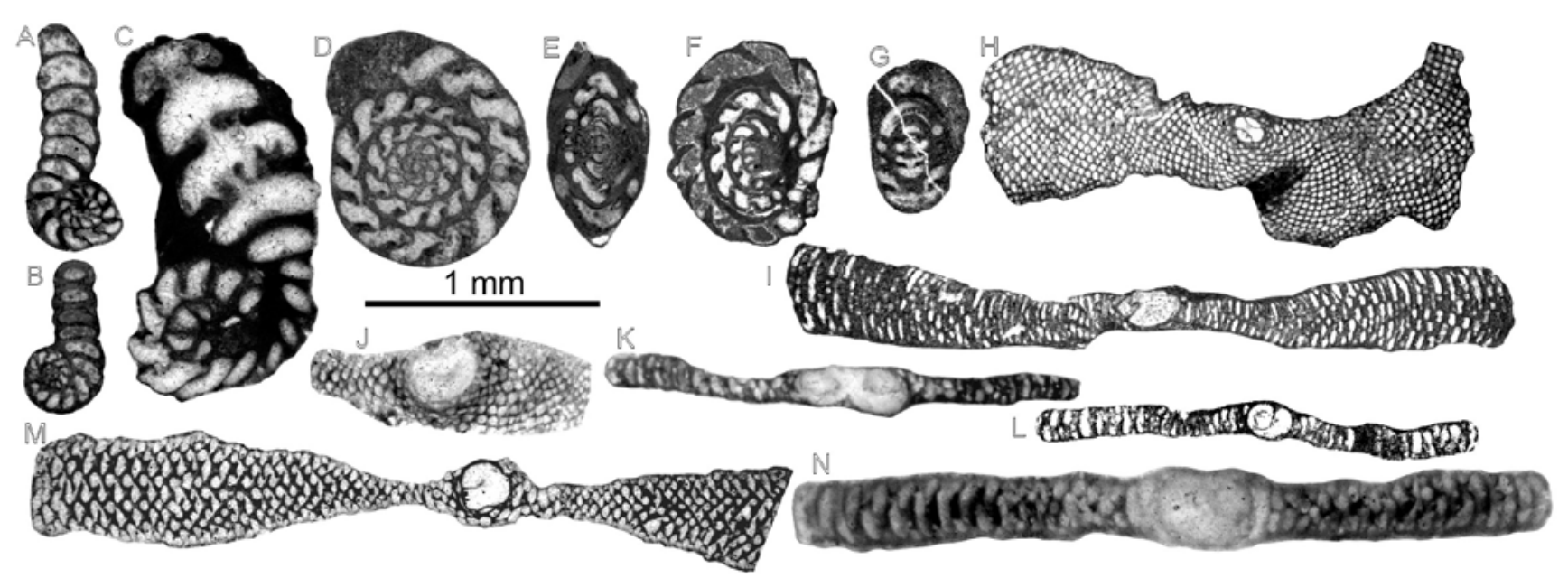

FIGURE 21. A-B) Spirolina austriaca. A-B: centered longitudinal sections. Specimen A: sample I 23; B: sample G 50. C) Sivasina egribucakensis longitudinal section, specimen from sample G 27. D-G) Penarchaias sp. D: centered equatorial section. E-F: oblique sections. G: subaxial section. Specimen D: sample G 28, E: sample G 37; F: sample G 42 and G: sample G 43. H-I) Orbitolites complanatus . H: equatorial section. I: oblique axial sections. Specimen H: sample G 25; I: sample I 50. J-K) Orbitolites minimus. J: equatorial section. K: axial section. Specimen J: sample P 5 and K: sample E 21. L-M) Orbitolites complanatus. L: axial section. M: oblique axial section. Specimen M: sample G 30 and L: sample SC 23. N) Orbitolites cotentinensis axial section, specimen from sample SC 30.

Remarks. The specimens studied are smaller than the specimens identified as P. glynnjonesi (type species) by Hottinger (2007) and Serra-Kiel et al. (2016).

Age. According to Hottinger (2007) and Serra-Kiel et al. (2016) this genus extends from Bartonian to Rupelian (Oligocene). Here, this genus was found between samples containing Alveolina munieri, indicating middle Lutetian 1 (A. munieri Zone) or SBZ14. Thus, the biostratigraphical range of this genus extends from middle Lutetian 1 or SBZ14 to Rupelian.

Family: Soritidae EHRENBERG, 1839

Subfamily: Soritinae EHRENBERG, 1839

GENUS Orbitolites LAMARCK, 1801

Type species: Orbitolites complanatus LAMARCK, 1801

Orbitolites minimus HENSON, 1950

Fig. 21J-K

1950 Orbitolites complanata Lamarck var. minima var. nov. Henson, p. 58; pl. 3, fig.1

2007 Orbitolites minimus Henson 1950. Hottinger, p. 10; pl. 15, figs. 6 and 9

Material. This species is present in the following sections: La Foz de Escalete, La Peña and La Osqueta (Figs. $6 ; 7 ; 11)$.

Description. Small test of discoidal, flattened morphology and annular-cyclic growth. The diameter of the shell for 17-19 annuli is around $3 \mathrm{~mm}$. Embryonic apparatus large, with a maximum diameter of $475 \mu \mathrm{m}$, measured in axial section, and $200 \mu \mathrm{m}$ in height. Juvenarium (nepionic stage) formed of 2-3 annuli. In axial section, this species shows an endoskeleton simpler than the endoskeleton of other species of this genus.

Age. This species is from a sample located between samples containg Nummulites crassus and $N$. aff. deshayesi (Fig. 6), which indicates middle Lutetian 2 (N. sordensis-N. crassus Zone) or SBZ15. Thus, the biostratigraphic range of this species is SBZ15, extentding into SBZ16, if its less precise occurrence in late Lutetian (sample O 4; Fig. 11) is considered.

Orbitolites complanatus LAMARCK, 1801

Fig. 21H-I, L-M

1961 Orbitolites complanatus $\mathrm{n}$. sp. Lehmann, p. 618-622; Pl, 1, figs. 1-4; pl. 2, figs. 1-3; Text-figs. 18-20

1972 Orbitolites complanatus Lamarck, 1801. Vanová, p. 77; pl. 18, fig. 1

1978 Orbitolites complanatus Lamarck. Le Calvez and Blondeau, pl. 3, fig. 1

2012a Orbitolites complanatus Lamarck, 1801. Rodríguez-Pintó et al., on-line Supplementary Material, pl. 13, figs. 13

Material. This species is present in the Gabardiella, Isuela and Sierra Caballera sections (Figs. 3-5).

Description. Test of discoidal, flattened morphology and annular-cyclic growth. Endoskeleton composed of septulum subdividing the annular chambers and stolons in crosswise-oblique disposition. The axial section of the embryonic apparatus is $190 \mu \mathrm{m}$ in diameter and 
$150 \mu \mathrm{m}$ in height. Juvenarium (nepionic stage) formed of 3-5 annuli.

Age. This species occurs between beds that contain Alveolina stipes and A. obtusa (Fig. 3), indicating early Lutetian (A. stipes Zone) or SBZ13. The association of O. complanatus with A. munieri (samples $\mathrm{G} 24$ and $\mathrm{G}$ 51; Fig. 3) indicates middle Lutetian 1 (A. munieri Zone) or SBZ14, whereas its association with Nummulites beaumonti (sample I 50; Fig. 4) indicates middle Lutetian 2 or SBZ15. Summarizing, according to the material studied the biostratigraphic range of this species extends from early Lutetian (SBZ13) to middle Lutetian 2 (SBZ15).

\section{Orbitolites cotentinensis LEHMANN, 1961}

Fig. 21N

1961 Orbitolites cotentinensis n. sp. Lehmann, p. 627-630; pl, 8, figs. 1-6; fig. 24, 25and 26

Material. This species is present in the Sierra Caballera section (Fig. 5).

Description. Test of discoidal, flattened morphology with a cyclic growth of annuli. Endoskeleton composed of septulum subdividing the annular chambers and stolons in crosswise-oblique disposition. The embryonic apparatus in axial section is $600 \mu \mathrm{m}$ in diameter and $350 \mu \mathrm{m}$ in height. Juvenarium (nepionic stage) formed of 4-5 annuli.

Remarks. This species differs from Orbitolites reicheli LEHMANN, 1961 and Orbitolites armoricensis LEHMANN, 1961 in the larger diameter of the proloculus

Age. Hottinger in Lehmann (1961) associated this species with Alveolina elongata which indicate early Bartonian or SBZ17 (Serra-Kiel et al., 1998). Here this species occurs in SBZ15 (sample SC 30; Fig. 5) which extends its bioestratigraphic range from middle Lutetian 2 (SBZ15) to early Bartonian (SBZ17).

Class: Globothalamea PAWLOWSKI et al., 2013

Order: “Textulariida” (DELAGE AND HÉROUARD, 1896) partim

Superfamily: Coscinophragmatacea THALMANN, 1951 Family: Haddoniidae Chapman, 1898

GENUS Haddonia CHAPMANN, 1898

Type species: Haddonia torresiensis CHAPMANN, 1898

\section{Haddonia heissigi HAGN, 1968}

\section{Fig. 22A-C}

1968 Haddonia heissigi n. sp. Hagn, p. 11-16; pl. 1 , figs. $1,3,4$; pl. 2, figs- $1-3$; pl. 3, figs. $1-2$, text figs. 3-7

1978 Haddonia heissigi. Matteucci, fig. 9.c; p. 397398; fig. 11 a-f
1980 Haddonia heissigi. Benjamini, pl. 4, fig. 10

1993 Haddonia heissigi. Schmidt and Jäger, pl.1-4-4

Material. This species is present in the Gabardiella and Isuela sections (Figs. 3; 4).

Description. The test shows an irregular morphology and protuberances on its external surface. The wall is composed of two layers. The inner layer has large pores aligned perpendicular to the surface. The external layer is composed of coarse agglutinated particles. Nepionic stage formed of a spherical proloculus about $95 \mu \mathrm{m}$ across, followed by chambers in planispiral arrangement. Apertures are located at the base of the chambers, with a small ridge in the base.

Remarks. This species has been interpreted to be living attached to the substrate, and was probably abundant in seagrass and reef environments of the inner shelf (Hagn, 1968).

Age. According to Hagn (1968) and Matteucci (1978) the biostratigraphic range of this species extends from Lutetian to Priabonian. Here, beds containing this species are interbeded with beds containing Alveolina stipes which indicates early Lutetian or SBZ13 (sample G 6; Fig 3). In the Isuela section (sample I 37; Fig. 4) this species occurs in an imprecise interval between SBZ14 and SBZ15. Thus, its biostratigraphic range is Lutetian-Priabonian.

Superfamily: Ataxophragmioidea SCHWAGER, 1877

Family: Coskinolinidae MOULLADE, 1965

GENUS Coskinolina STACHE, 1875

Type species: Coskinolina liburnica STACHE, 1875

Coskinolina cf. perpera HOTTINGER AND DROBNE, 1980 Fig. 22D-E

Material. This species is present in the Boltaña Fm.

Description. Test with high-conical morphology. The wall is thick; the poor state of preservation of the specimens did not allow to observe the pseudo-keriothecal texture.

Remarks. The scarce material available and the absence of centered longitudinal sections did not allow its specific determination.

Age. In the material studied this species is associated with Alveolina decastroi and A. cremae (sample G1, see Fig. 3), indicating middle Cuisian (A. dainelli Zone) or SBZ11.

Coskinolina roberti SCHLUMBERGER, 1905

Fig. 22F-T 


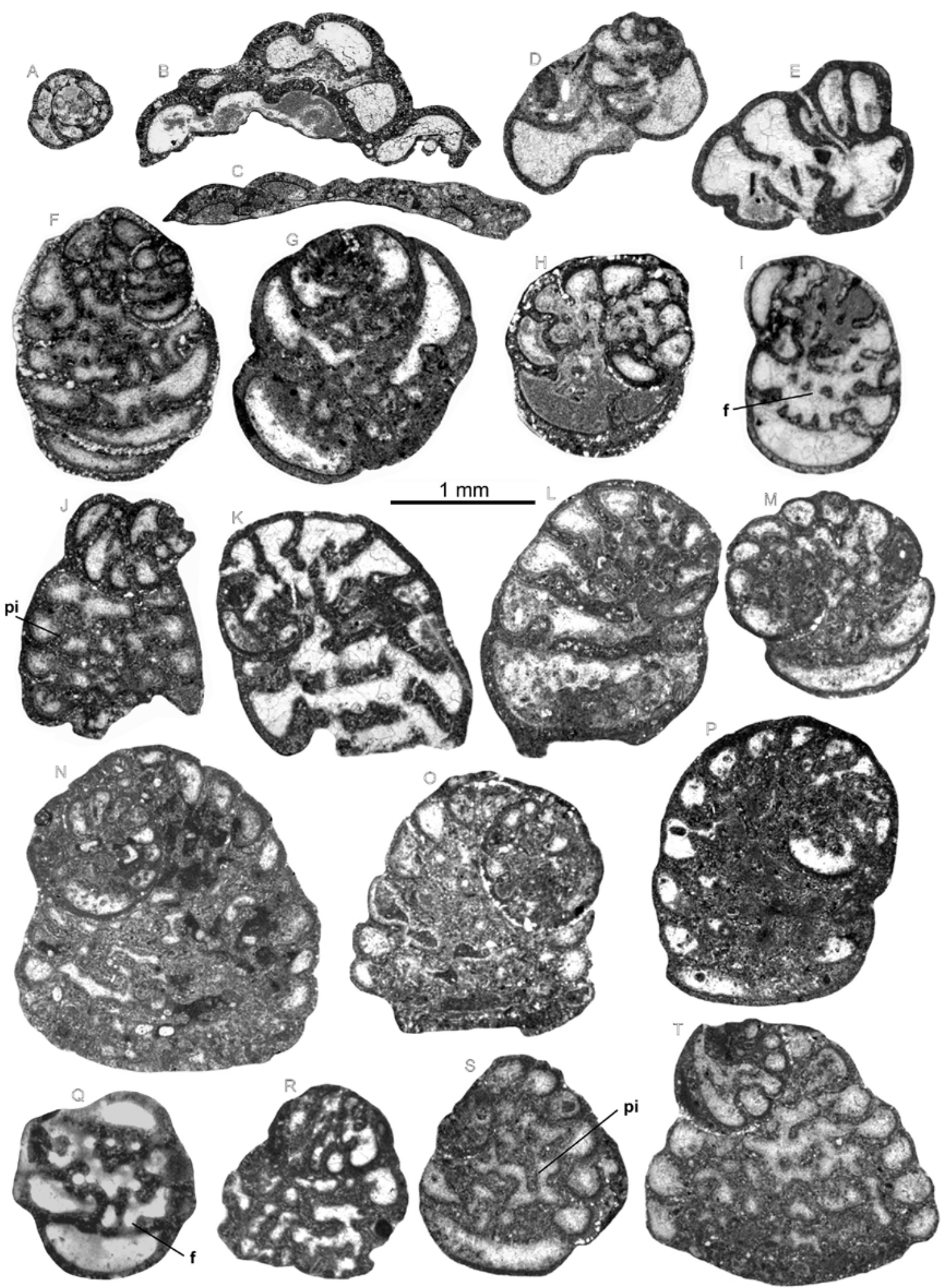

FIGURE 22. A-C) Haddonia heissigi. A: spherical proloculus. B-C: perpendicular to coiling axis sections. Specimens A, B: sample I 37 and C: sample G 6. D-E) Coskinolina cf. perpera. D: uncentered longitudinal section. E: oblique section. Specimens D: sample G 2 and E: sample G 1. F-T) Coskinolina roberti. F: Iongitudinal section, G-M: oblique longitudinal sections, note the foramen distribution in I. N-P: Iongitudinal sections. Q: basal section. Note the foramen distribution in Q. R-S: oblique longitudinal sections, note the pilar in S. T: Iongitudinal sections. Specimen F: sample I 28; G, H: sample | 31; I: sample I 24; J: sample I 33; K, R: sample I 50; L: sample | 41; M: sample I 38; N: sample I 48; O, T: sample | 42; P, S: sample | 45 and Q: sample P 10. Abbreviations: f: foramen; pi: pillar. 
1980 Coskinolina (Coskinolina) roberti (SCHLUMBERGER, 1905). Hottinger and Drobne, p. 228-229; pl. 9, figs. 1-16

2012a Coskinolina roberti (SCHLUMBERGER, 1905). Rodríguez-Pintó et al., on-line Supplementary Material, pl. 3, figs. 1-14

Material. This species is frequent in the following sections: Gabardiella, Isuela, Sierra Caballera, La Foz de Escalete, La Peña and Murillo de Gállego (Figs. 3-8).

Description. The megalospheric forms show a highconical morphology. The wall is thick and the texture pseudokeriothecal. The nepionic stage is formed of protoconch and deuteroconch in eccentric location, followed by 7-10 chambers with high-trochospiral arrangement (Fig. 22F). The neanic stage is formed of 5-7 chambers in uniserial arrangement (Fig. 22N-O). The endoskeleton is formed of pillars beginning in the $3^{\text {rd }}-4^{\text {th }}$ nepionic chamber. At the apex of the cone the diameter ranges $330-375 \mu \mathrm{m}$, with a maximum diameter of $1.5-2.0 \mathrm{~mm}$. The axial length is $2.0-$ $2.3 \mathrm{~mm}$ and the axial plane cuts $4-5$ pillars. The pillars are discontinuous from one chamber to the next (Fig. 22J). The chamber sutures are slightly depressed. The apertural face is slightly convex, and the apertures show a cribrate distribution (Fig. 22I, Q).

Age. The biostratigraphic range of Coskinolina roberti extends from early Lutetian (SBZ13) to late Lutetian (SBZ16). The SBZ13 is characterized by its association with Alveolina stipes (sample G 21; Fig. 3), indicating early Lutetian (A. stipes Zone). The SBZ14 is characterized by the association of $C$. roberti with $A$. munieri (samples $\mathrm{G}$ 24, I 16, I 17, I 20 and I 21; Figs. 3; 4), indicating middle Lutetian 1 (A. munieri Zone). In the sections studied, the SBZ15 is characterized by the alternation of samples with Coskinolina roberti with samples with Nummulites crassus (Fig. 5; 7). The SBZ16 is characterized by the stratigraphic location of $C$. roberti in samples overlying samples with $N$. aturicus and N. deshayesi (Fig. 5).

Order: Rotaliida (DELAGE AND HÉROUARD, 1896)

Superfamily: Chilostomellacea BRADY, 1881

Family: Gavelinellidae HOFKER, 1956

\section{Gavelinellidae indet.}

\section{Fig. 23A-F}

1972 Gyroidina subangulosa (Plummer, 1926), Samuel et al., pl. 37, fig. 1-6

Material. This species is present in the Gabardiella section (Fig. 3).

Description. The test is bilamellar with coarse pores and low-trochospiral growth. The dorsal side is convex and smooth; the ventral side is slightly convex and displays an umbo with beads (Fig. 23C). The lamination is composed of a thicker and perforate outer layer and a thin inner layer. Between both layers there is a marked dark median layer. The proloculus is spherical with a diameter of $80-100 \mu \mathrm{m}$ (Fig. 23A, E). The equatorial diameter is $0.77 \mathrm{~mm}$ with 21 chambers and the longitudinal diameter is $0.52 \mathrm{~mm}$.

Age. This species is located in samples interbedded with Alveolina munier (samples G 38, G 39 and G 40 (Fig. 3), indicating middle Lutetian 2 or SBZ14.

Superfamily: Planorbulinoidea schwager, 1877 Family: Cymbaloporidae CUSHMAN, 1927

Subfamily: Fabianinae DELOFFRE AND HAMAOUI, 1973

GENUS Fabiania SILVESTRI, 1924

Type species: Patella (Cymbolia) cassis OPPENHEIM, 1896

Fabiania cassis (OPPENHEIM, 1896)

\section{Fig. 23G-J}

1973 Fabiania cassis (Oppenheim). Deloffre and Hamaoui, pl. 6, figs. 1-7; pl. 7, fig. 1-3 and 5; pl. 8, fig. 1-6pl. 9, fig. 1-3, 5-7; pl. 10, fig. 1-9

Material. This species is frequent in the following sections: Gabardiella, Isuela, Sierra Caballera, La Foz de Escalete, La Peña, Murillo, Villalangua and La Osqueta (Figs. 3-9; 11).

Description. Test of high-conical morphology. Nepionic stage composed of proloculus and two chambers in low-trochospiral arrangement. Neanic stage formed of chambers in high-trochospiral arrangement. The diameter of the proloculus varies between $145 \mu \mathrm{m}$ and $160 \mu \mathrm{m}$. The lateral wall shows coarse pores and an exoskeleton formed of folds of the inner layer (Fig. 23I). The peripheral sections show a pseudo-polygonal network formed of folds of the inner layer over the outer lamella of the chamber lateral wall (Fig. 23I). Apertures in interiomarginal location (Fig. $23 \mathrm{G})$. The septum backwards to umbiliculus overlaps the previous septum forming a massive accumulation of folia.

Age. The biostratigraphic range of Fabiania cassis extends from early Lutetian (SBZ13) to late Lutetian (SBZ16). The stratigraphic record of SBZ13 is characterized by its association with Alveolina stipes (sample I 7; Fig. 4), indicating early Lutetian (A. stipes Zone). SBZ14 is characterized by the association of $F$. cassis with $A$. munieri (samples G 24, G 34, G 35 and G 36; Fig. 3), and SBZ15 is characterized by its association with Nummulites crassus (samples SC 38 and P 21; Figs. $5 ; 7$ ), indicating middle Lutetian 2 (N. sordensis-N. crassus Zone). Finally, SBZ16 is characterized by the occurrence of $F$. cassis overlying samples with $N$. aturicus 


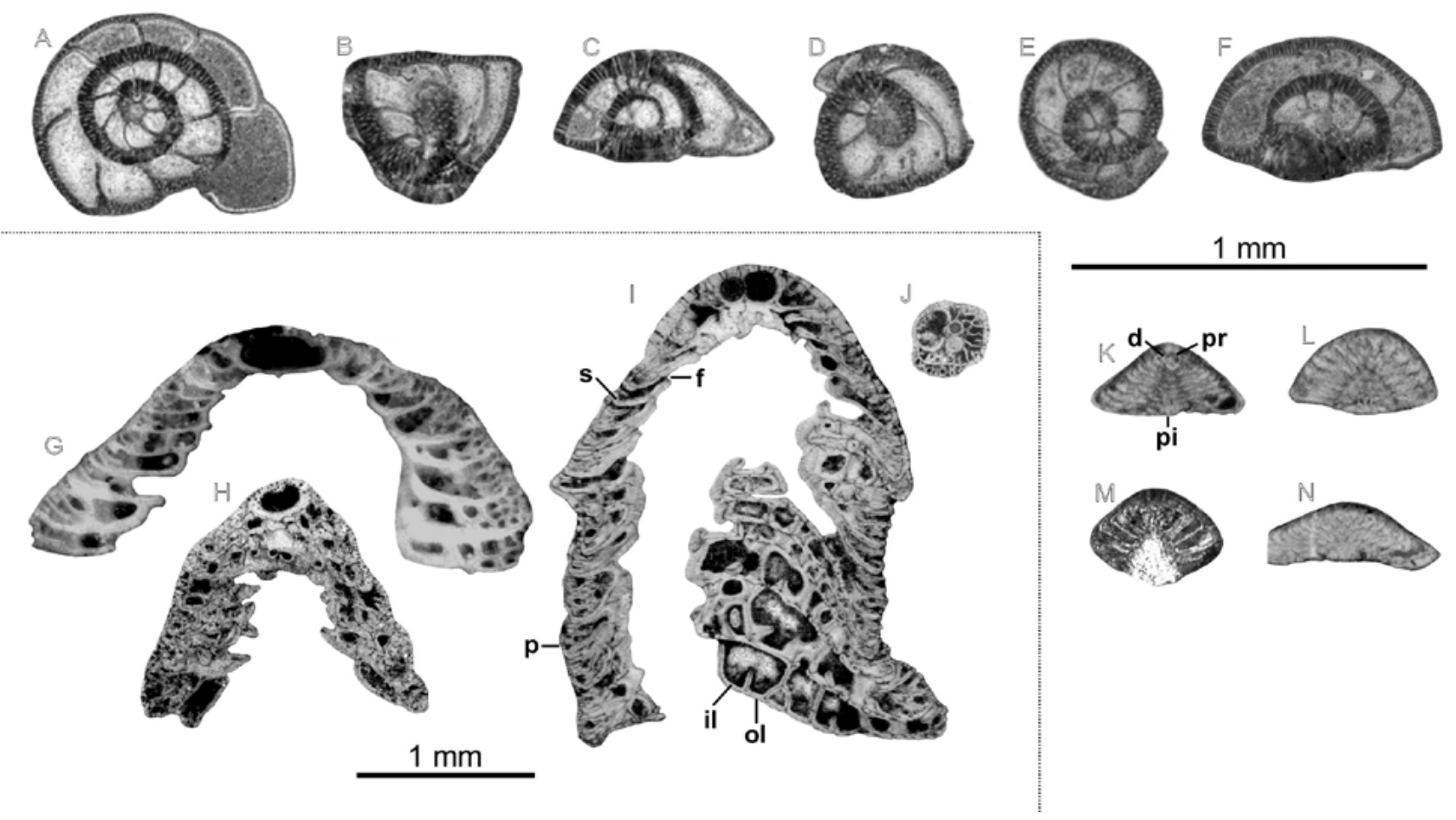

FIGURE 23. A-F) Gavelinellidae indet. A: centered perpendicular to coiling axis section. B: uncentered longitudinal section. C: centered longitudinal section. D: uncentered perpendicular to coiling axis section. E: centered perpendicular to coiling axis sections. F: oblique section. Specimens A, C, D: sample G 40; B, F: sample G 39 and E: sample G 38. G-J) Fabiania cassis. G, H: longitudinal centered sections. I: slightly longitudinal section. J: Nepionic stage. Specimen G: sample E 41; H: sample I 33; I: sample G 33 and J: sample G 36. K-N) Halkyardia minima. K: centered longitudinal section. L: oblique sections. M: uncentered longitudinal section. N: oblique sections. Specimen K: sample G 67; L: sample G 62; M: sample SC 19 and N: sample G 48. Abbreviations: pr: proloculus; s: septum; p: pore; f: foramen; d: deuteroconch; il: inner layer; ol: outer layer; pi: pile.

and $N$. deshayesi (Fig. 5), indicating late Lutetian (N. herbi-N. aturicus Zone).

Subfamily: Halkyardiinae KUDO, 1931

GENUS Halkyardia HERON-ALLEN AND EARLAND IN HALKYARD, 1918

Type species: Cymbalopora radiata vON HAGENOW var. minima LIEBUS, 1911

\section{Halkyardia minima (LIEBUS, 1911)}

\section{Fig. 23K-N}

1969 Halkyardia minima (Liebus). Cimerman, p. 298-300; pl. 58, figs. 1-6

1973 Halkyardia minima (Liebus). Deloffre and Hamaoui. pl. 2, figs. 1-7.

1975 Halkyardia minima (Liebus). Colom, p. 239; pl. 27, fig. 1; figs. 85.1-4

1994 Halkyardia minima (Liebus, 1911). Pignatti, pl. 8 , figs. $4-5$

2000 Halkyardia cf. minima (Liebus). Sirel, pl. 3; figs. $15-16$

2001 Halkyardia minima (Liebus) 1911. Romero, p. 180-181; pl. 7, figs. 1-11

2003 Halkyardia minima (Liebus). Sirel, pl. 8, figs. 16 and 20 2012a

Halkyardia minima (Liebus). Rodríguez-Pintó et al., on-line Supplementary Material, pl. 13, figs. 13

Material. This species is present in the Gabardiella, La Foz de Escalete, Villalangua and Campo Fenero sections (Figs. 3; 6; 9; 12).

Description. Shell of small size and conical morphology. Cone diameter varies between $0.45-0.55 \mathrm{~mm}$ and the cone height is around $0.2 \mathrm{~mm}$. The dorsal side is convex and the ventral side flat or slightly convex. Embryonic apparatus composed of protoconch and deuteroconch (Fig. 23K) followed by chambers distributed in cycles. The umbilical area shows horizontal lamellae and thin pillars (Fig. 23L).

Age. Cimerman (1969) and Romero (2001) found this species in Bartonian and Priabonian rocks of Slovenia and Spain (Igualada Basin). Here this species is present in samples intercalated with Alveolina munieri, indicating middle Lutetian 1 or SBZ14. It also occurs in samples intercalated with Nummulites aff. deshayesi and N. crassus (Fig. 6), indicating middle Lutetian 2 or SBZ15. The stratigraphic location and biostratigraphic context suggest that this species belongs to SBZ16 (Figs. 3; 9), with a 
biostratigraphic range extending from middle Lutetian 1 (SBZ14) to late Eocene (Priabonian).

Family: Victoriellinae CHAPMAN AND CRESPIN, 1930 GENUS Gyroidinella LE CALVEZ, 1949

Type species: Gyroidinella magna LE CALVEZ, 1949

Gyroidinella levis (GRIMSDALE, 1952)

Fig. 24A-C

1952 Eorupertia incrassata (Uhlig). Grimsdale, p. 239; pl. 20, figs. 15-21

1971 Eorupertia cristata laevis (Grimsdale). Boulanger and Poignant, pl. 3, figs. 5-6

2014 Gyroidinella levis (Grimsdale, 1952). Hottinger, p. 187, pl. 9.10, figs. 1-13.

Material. This species is present in the Gabardiella, Isuela and Sierra Caballera sections (Figs. 3-5).

Description. Trochospiral test with flattened umbilical side and concave dorsal side. Smooth dorsal side with marked pores. Length in axial section is around $1.5 \mathrm{~mm}$, and length in section perpendicular to the coiling axis is $1.4 \mathrm{~mm}$ for 12-14 chambers. Small proloculus with a diameter of ca. $120 \mu \mathrm{m}$ (Fig. 24C).

Age. According to Hottinger (2014) the biostratigraphic range of this species is from SBZ10 (Cuisian) to SBZ13 (early Lutetian). In the Gabardiella and Isuela sections this species was found intercalated with samples contaning Alveolina stipes (Figs. 3; 4) which indicates early Lutetian (A. stipes Zone) or SBZ13.

\section{Gyroidinella eocaenica (SACAL AND DEBOURLE, 1957)}

\section{Fig. 24D-F}

2000 Gyroidinella eocaenica (Sacal and Debourle, 1957). Sztràkos, p. 40; pl. 2, fig. 11.

2014 Gyroidinella eocaenica (Sacal and Debourle, 1957). Hottinger, p. 190, pl. 9.11, figs. 1-16.

Material. This species is present in the Gabardiella and Isuela sections (Figs. 3; 4).

Description. Test with trochospiral growth. Thick lateral wall with coarse pores. Flat or slightly convex ventral side and concave dorsal side. In axial section, the diameter for three whorls is $c a$. $2 \mathrm{~mm}$ and the length of the section perpendicular to the coiling axis is about $1.7 \mathrm{~mm}$ for 10 chambers. Septum inclined backwards in dorsal side (Fig. 24D). The diameter of the proloculus is $c a$. $150 \mu \mathrm{m}$ (Fig. 24.E). Foramen located in interiomarginal position.

Age. According to Hottinger (2014) the biostratigraphic range of this species is SBZ13 (early Lutetian). Here, the biostratigraphic range of this species is SBZ13-SBZ14.
Its stratigraphic location intercalated with samples with Alveolina stipes (Figs. 3; 4) indicates early Lutetian (A. stipes Zone) or SBZ13. The SBZ14 is characterized by the association of $G$. eocaenica with A. munieri (sample G 36; Fig. 3), indicating middle Lutetian 1 (A. munieri Zone). Thus, the biostratigraphic range of this species extends from SBZ13 (early Lutetian) to SBZ14 (middle Lutetian 1).

\section{Gyroidinella magna LE CALVEZ, 1949}

\section{Fig. 24G-M}

2014 Gyroidinella magna (Sacal and Le Calvez, 1949). Hottinger, pl. 9.10, fig. 17.

Material. This species is present in the Gabardiella, Isuela, Sierra Caballera, La Peña, La Foz de Escalete, Murillo de Gállego, Villalangua, San Felices, La Osqueta sections (Figs. 3-11).

Description. Shell with trochospiral growth. Flat umbilical side and conical dorsal side. Slightly depressed sutures in subequatorial section (Fig. 24H, L). In axial section, the diameter for three whorls is around $2.3 \mathrm{~mm}$ and the length of the section perpendicular to the coiling axis is around $2.4 \mathrm{~mm}$ for $18-20$ chambers. Proloculus about $190 \mu \mathrm{m}$ in diameter.

Age. According to Hottinger (2014) the biostratigraphic range of this species is SBZ13 (early Lutetian). Here, this species was found in Lutetian rocks. In the SBZ13 it is associated with Alveolina callosa (sample SC 14; Fig. 5), and in SBZ14 it is associated with A. munieri (samples G 23 and G 24; Fig. 3), indicating middle Lutetian 1 (A. munieri Zone). Samples with this species are intercalated with Nummulites crassus and N. aff. deshayesi (Fig. 5), indicating middle Lutetian 2 (N. sordensis-N. crassus Zone) or SBZ15. Finally, samples with this species are intercalated with $N$. aturicus and $N$. deshayesi (Figs. 5; 7), indicating late Lutetian (N. herbi-N. aturicus Zone) or SBZ16. Thus, the biostratigraphic range of this species extends from SBZ13 (early Lutetian) to SBZ16 (late Lutetian).

GENUS Korobkovella HAGN AND OHMERT, 1971

Type species: Truncatulina grosserugosa GÜMBEL, 1870

\section{Korobkovella grosserugosa (GÜMBEL, 1870)}

\section{Fig. 24N-P, R-S}

1987 Korobkovella grosserugosa. Loeblich, Jr and Tappan, p. 595-596; pl. 658, figs. 1-9, p. 180-181; pl. 9, figs. $1,3-6$

2001 Korobkovella cf. grosserugosa. Romero, p. 180-181; pl. 9, figs. 1, 3-6

Material. This species is present in the Gabardiella and Sierra Caballera sections (Figs. 3; 5). 



P

kl


FIGURE 24. A-C) Gyroidinella levis. A-C: centered axial sections. Specimen A: sample SC 1; B: sample G 7 and C: sample I 4. D-F) Gyroidinella eocaenica. D: uncentered perpendicular to coiling to axis section. E: subaxial section. F: oblique section. Specimens D, E: sample G 36 and F: sample G 33. G-M) Gyroidinella magna. G-H: subaxial sections. I-J: centered perpendicular to coiling to axis sections. K-L: uncentered perpendicular to coiling to axis sections. M: subaxial sections. Specimen G: sample G 45; H, K: sample G 23; I: sample G 58; J: sample V 8; L: sample G 26 and M: sample G 24. N-P) Korobkovella grosserugosa. N-O: oblique subaxial sections. P: subaxial section, note the keel. Specimen N: sample SC 53; O: sample G 71; P: sample SC 53. Q) Victoriella conoidea longitudinal section, specimen from sample I 54. R-S) Korobkovella grosserugosa. R: oblique subaxial sections. S: oblique section, note the proloculus. R: sample G 39 and S: sample SC 53. Abbreviations: pr: proloculus; f: foramen; bd: bead; spc: spiral canal; sf: septal flat; sut: suture; ilsp: intraseptal interlocular space; uf: umbilical flat; ump: umbilical pile; kl: keel. 
Description. Test low-trochospiral with a flat or convex dorsal side and a slightly convex umbilical side. Thick lateral wall with coarse pores and marked beads (Fig. 24S). Septum inclined backwards in dorsal side. The dorsal side shows a keel without pores (Fig. 24P).

Age. Romero (2001) found this species in Bartonian rocks from the Igualada Basin (Spain). In the material studied this species is located in samples intercalated with Alveolina munieri (A. munieri Zone), indicating middle Lutetian 1 or SBZ14 (Fig. 3). Samples with $K$. grosserugosa are intercalated with Nummulites aturicus (Figs. 5), indicating late Lutetian (N. herbi-N. aturicus Zone) or SBZ16. Thus, the biostratigraphic range of this species extends from SBZ14 (middle Lutetian) to SBZ17 (early Bartonian).

GENUS Victoriella CHAPMAN AND CRESPIN, 1930

Type species: Victoriella conoidea RUTTEN, 1914

Victoriella conoidea (RUTTEN, 1914)

Fig. 24Q

1987 Victoriella conoidea. Loeblich and Tappan, p. 596; pl. 657, figs. 11-13

1993 Victoriella conoidea (Rutten). Robinson and Wright, p. 307, 309; figs. 16.5-6

2007 Victoriella conoidea (Rutten, 1914). Serra-

Kiel et al., p. 369; pl. 2, figs. 8 and 9

Material. This species occurs in the Isuela section (Fig. 4).

Description. Test with low-trochospiral growth. The first whorls show a conical morphology and are followed by whorls with enlarged morphology. The sutures between chambers are depressed. Thick wall with marked pores and beads (Fig. 24Q). The length in longitudinal section is $1.85 \mathrm{~mm}$ and in sections perpendicular to the coiling axis is $1.3 \mathrm{~mm}$.

Age. According to Robinson and Wright (1993) and Serra-Kiel et al. (2007) the biostratigraphic range of this species is late Eocene to Oligocene. Here, this species was found associated with Nummulites deshayesi (sample I 54; Fig. 4), indicating late Lutetian (N. herbi-N. aturicus Zone) or SBZ16. Consequently, its biostratigraphic range extends from late Lutetian to Oligocene.

Superfamily: Acervulinoidea SCHULTZE, 1854

Family: Acervulinidae SCHULTZE, 1854

GENUS Solenomeris DOUVILLE, 1924

Type species: Solenomeris ogormani DOUVILLE, 1924

Solenomeris cf. ogormani DOUVILLE, 1924

\section{Fig. 25A-C}

2003 Solenomeris ogormani Douvillé, 1924. Bassi, p. 339-341; figs. 1 and 2
Material. This species is present in the Gabardiella, Isuela, Sierra Caballera, La Foz de Escalete, La Peña, Murillo, Villalangua and La Osqueta sections (Figs. 3-9; 11).

Remarks. This species was formely considered to be a red algae. Later, Perrin (1987, 1994) and Bassi (2003) showed that its morphostructure was rather the morphostructure of an acervulinid foraminifera. As pointed out by the later author "each layer of the test consists of an expanse chamber subdivided into small, chamberlets connected by tubular passages". Unfortunately, the embryonic apparatus could not be observed, leading to a less well-defined taxonomic attribution.

Age. This species has been interpreted to be living attached to the substrate, especially in seagrass and reef environments of the inner shelf (Silva-Casal, 2017; Tomás et al., 2016). It has not biostratigraphic significance since it ranges from early Paleogene (Plaziat and Perrin, 1992; Perrin, 1994) to late Lutetian.

GENUS Gypsina CARTER, 1877

Type species: Polytrema planum CARTER, 1877

“Gypsina” moussaviani BRUGNATTI AND UNGARO, 1987 Fig. 25D-G

1987 “Gypsina” moussaviani n. sp. Brugnatti and Ungaro, p. 9-12; pl. 5, figs. 1-4

Material. This species is frequent in the Gabardiella, Isuela, Sierra Caballera, La Foz de Escalete, La Peña, Murillo, Villalangua and La Osqueta sections (Figs. 3-9;11).

Remarks. Brugnatti and Ungaro (1987) described this species following morphological and structural criteria. In axial section the chambers show an arcuate outline with stolons located at the base of the chambers (Fig. 24EF). According to these authors the concave morphology of the shell indicates an epiphytic habitat and suggests attachement to the substrate. This species was probably abundant in seagrass and reef environments of the inner shelf (Silva-Casal, 2017; Tomassetti et al., 2016). Its biostratigraphic significance is moderate since it occurs throughout the Lutetian.

GENUS Sphaerogypsina GALLOWAY, 1933

Type species: Ceriopora globulus REUSS, 1848

Sphaerogypsina globulus REUSS, 1848

Fig. 25H-I

1971 Sphaerogypsina globula (Reuss, 1848). Ferrer, p. 57 ; pl. 7, fig. 17

1975 Sphaerogypsina globula (Reuss). Colom, p. 241; pl. 28, fig. 1 


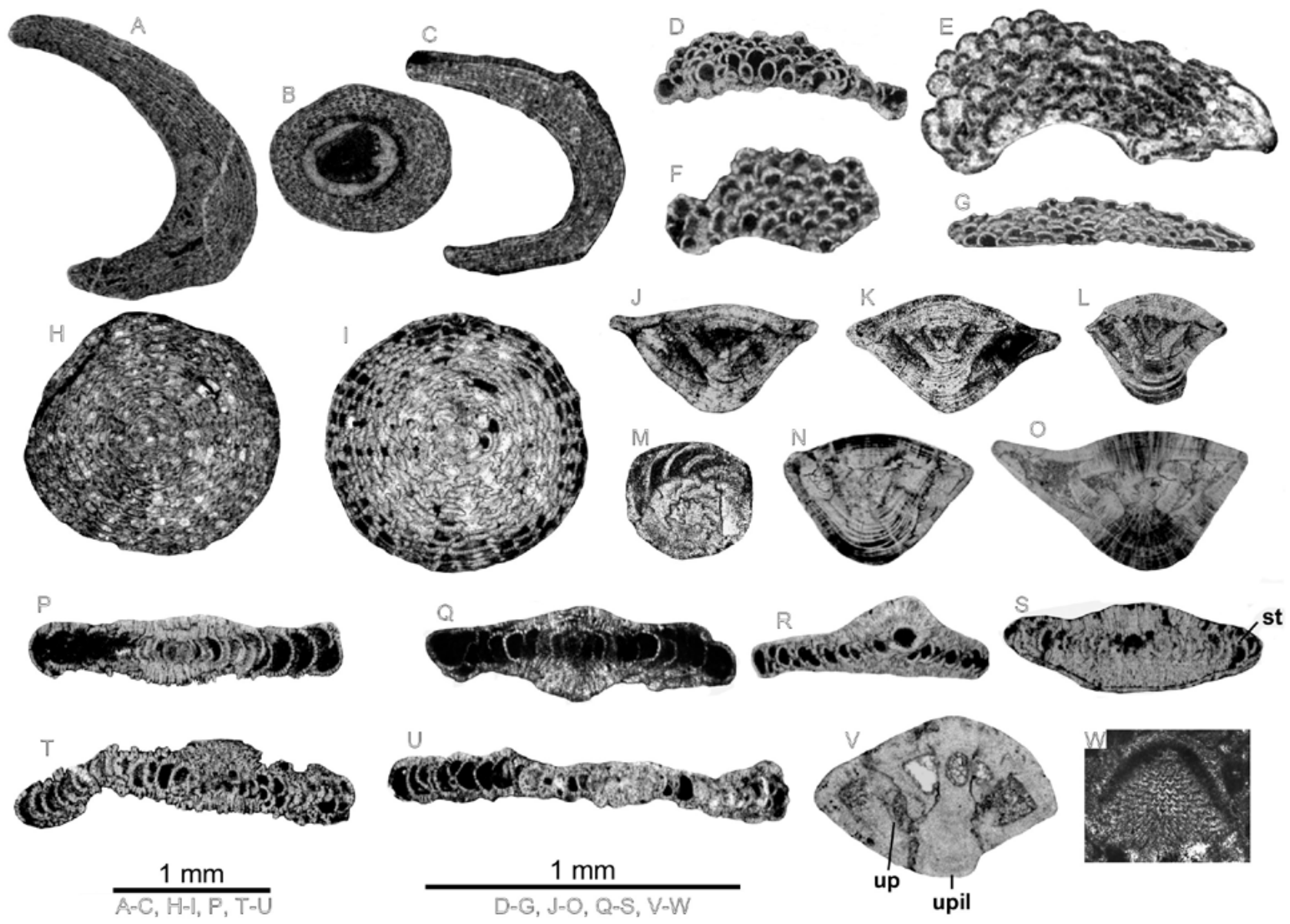

FIGURE 25. A-C) Solenomeris cf. ogormani. Specimen A: sample G 50; B: sample I 33 and C: sample V 10. D-G) "Gypsina" moussaviani. Specimen D: sample G 38; E: sample I 47; F: sample G 50 and G: sample G 30. H-I) Sphaerogypsina globulus. Specimen H: sample P 25 and I: sample G 59. J-O) Asterigerina rotula. J-L: uncentered axial sections. M: uncentered equatorial section. N-O: uncentered axial sections. Specimens J, K: sample SC 19; L: sample SC 1; M: sample SC 16 and N-O: from sample G 41. P) Planolinderina? axial section; note the embryonic apparatus with two chambers. Specimen from sample G 69. Q-S) Linderina cf. brugesi. Q: axial section. R: oblique section showing the orbitoidal growth. S: subaxial section showing the involute lamellar pattern. Q: sample SC 40; R: sample G 48 and S: sample G 64. T-U) Planolinderina? Subaxial sections.; T: sample G 62 and U: sample I 38. V) Rotorbinella hensoni axial section. specimen from sample G 71. W) Chapmanina gassinensis sublongitudinal section, specimen from sample SC 23. Abbreviations: st: stolon; up: umbilical plate; upil: umbilical pile.

1979 Sphaerogypsina globula (Reuss). Drobne et al., p. 185; pl. 4, figs. 3

1994 Sphaerogypsina globulus (Reuss, 1848). Pignatti, pl. 3, fig. 6-7

2000 Sphaerogypsina globula (Reuss). Sirel, pl. 3, fig. 17

2001 Sphaerogypsina globula (Reuss, 1847). Romero, p. 184; pl. 12, figs. 1-4

2012a Sphaerogypsina globula (Reuss). Rodríguez-Pintó et al., on-line Supplementary Material, pl. 13, figs. 13

Material. This species occurs in the Gabardiella, Sierra Caballera, La Foz de Escalete, La Peña and Villalangua and Campo Fenero sections (Figs. 3; 5-8; 12).

Remarks. Test spherical. Chambers distributed in the sphere and subdivided in chamberlets with chessboard pattern (sensu Hottinger, 2006). The ceilings of the chamberlets are flat or slightly concave (Fig. 25I) and its wall shows coarse pores. The apertures are located at the base of the lateral wall and connect the chamberlets of adjacent chambers.

Age. Romero (2001) identified this species in Bartonian rocks from the Igualada Basin (Spain) and Pignatti (1994) in Priabonian rocks from the Maiella (Italy), pointing its limited biostratigraphic significance. In the material sudied this species is associated with Alveolina munieri (sample G 36; Fig. 3), indicating middle Lutetian 1 (A. munieri Zone) or SBZ14. Besides, it occurs between samples that contain Nummulites crassus and $N$. aff. deshayesi (Fig. 6), indicating middle Lutetian 2 (N, sordensis-N. crassus Zone) or SBZ15, and between samples with $N$. aturicus and N. deshayesi (Figs. 5; 7) which indicates late Lutetian or SBZ 16. Finally, this species is also found in beds overlying 
deposits containing $N$. biarritzensis and $N$. beaumonti (sample CF 6; Fig. 12), indicating early Bartonian or SBZ17. Summarizing, its biostratigraphic range is middle Lutetian 1 (SBZ14) to Oligocene.

Superfamily: Asterigerinacea D'ORBIGNY, 1839

Family: Asterigerinidae D'ORBIGNY, 1839

GENUS Asterigerina D'ORBIGNY, 1839

Type species: Asterigerina carinata D'ORBIGNY, 1839

Asterigerina rotula (KAUFMAN, 1867)

Fig. 25J-O

1979 Asterigerina rotula (Kaufman). Drobne et al., p. 185 ; pl. 4 , figs. 5

2001 Asterigerina rotula (Kaufman, 1867). Romero, p. 185 ; pl. 13 , figs. $1-6$

Material. This species is present in the Gabardiella and Sierra Caballera sections (Figs. 3; 5).

Description. Test hyaline, with asymmetrical biconvex outline in axial section. The umbilical side shows a marked umbo (Figs. 25J, K, N; 240). The septula are falciform, inclined backwards in subequatorial section (Fig. 25M). The periphery is carinate.

Age. Drobne et al. (1979) found this species in the Oligocene of Slovenia and Romero (2001) identified it in the Bartonian in the Igualada Basin (Spain). Here, it is associated with Assilina spira abrardi and Nummulites leheneri (samples SC 16; Figs. 3; 5), indicating early Lutetian or SBZ13. Its occurrence in sample G 41 (Fig. 3) between samples with Alveolina munieri (A. munieri Zone) indicates middle Lutetian 1 or SBZ14. Thus, the biostratigraphic range of this species extends from early Lutetian to Oligocene.

Superfamily: Orbitoidoidea SCHWAGER, 1876

Family: Linderinidae LOEBLICH AND TAPPAN, 1986

GENUS Linderina SCHLUMBERGER, 1893

Type species: Linderina brugesi SCHLUMBERGER, 1893

\section{Linderina brugesi SCHLUMBERGER, 1893}

Fig. 25Q-S

1999 Linderina brugesi Schlumberger. FerràndezCañadell and Serra-Kiel, figs. 2.4 and 2.5

Material. This species is present in the Gabardiella, Sierra Caballera and La Peña sections (Figs. 3; 5; 7).

Remarks. Shell of lenticular morphology and involute arrangement of lamellae. Chambers with annular-cyclic growth of orbitoidal type. Lateral thickness of the test formed by the superposition of the successive involute outer lamellae of the different chambers. Stolon in crosswise oblique distribution, alternately in axial rows (Fig. 25S).
The axial length is around $1 \mathrm{~mm}$ and the thickness is $c a$. $0.300 \mathrm{~mm}$.

Age. The presence of this species in SBZ14 is justified by its intercalation with beds containing Alveolina munieri (Fig. 3), indicating middle Lutetian 1 (A. munieri Zone). The belonging of L. brugesi to SBZ15 is justified by its stratigraphic location between samples with the association Nummulites crassus - $N$. aff. deshayesi and samples with N. deshayesi (sample P 24; Fig. 7). Finally, L. brugesi is associated with N. aturicus (sample SC 40; Fig. 5), indicating late Lutetian (N. herbi-N. aturicus Zone) or SBZ16. In sum, its biostratigraphic range is SBZ14 to SBZ16.

Superfamily: Planorbulinacea schwager, 1877

Family: Planorbulinidae schwager, 1877

GENUS Planolinderina FREUDENTHAL, 1969

Type species: Planolinderina escornebovensi FREUDENTHAL, 1969

\section{Planolinderina? FREUDENTHAL, 1969}

Fig. 25P-U

2001 Planolinderina? sp. Romero, p. 175-177, pl. 12, fig.7; pl. 14, figs. 1-6; pl. 15, figs. 1-6, 6

Material. This species is present in the Gabardiella and Isuela sections (Figs. 3; 4).

Remarks. Three axial sections showing a discoidal, practically flat, morphology, convex at the polar zone because of the involute lamellae of early chambers. Later the chambers show an evolute growth pattern. The walls of the chambers show coarse pores. The embryonic apparatus seems formed of two chambers (Fig. 25P). The lack of centered equatorial sections in the material studied hinders a more precise taxonomic attribution.

Age. Romero (2001) identified this taxon in the Bartonian from Igualada Basin (Spain). In the sections studied this genus has an imprecise biostratigraphic range between SBZ14 and SBZ15 (sample I 38; Fig. 4). In the Gabardiella section this species occurs in samples G 62 and G 69 (Fig. 3) belonging to late Lutetian or SBZ 16. Thus, its complete biostratigraphic range extends from middle Lutetian 2 (SBZ15) to Bartonian.

Superfamily: Rotalioidea ehrenberg, 1839

Family: Rotaliidae EHRENBERG, 1839

Subfamily: Rotaliinae EHRENBERG, 1839

GENUS Rotorbinella BANDY, 1944

Type species: Rotorbinella colliculus BANDY, 1944

Rotorbinella hensoni (SMOUT, 1954)

Fig. 25V

1954 Rotalia hensoni n. sp. Smout, p. 45; pl. 15, fig. 8 
2001 Rotorbinella sp. Romero, p. 174-175; pl. 16, figs. 1-5, 7-9

2006 Rotorbinella sp. Hottinger, p. 86; pl. 2, figs. $11-16$

2014 Rotorbinella hensoni (SMOUT, 1954). Hottinger, p. 24; Figs. 3.2, 3.3A-F; pl. 3.2, figs. 1-13

Material. This species is present in the Gabardiella section (Fig. 3).

Description. Test of small size with bilamellar-perforate wall, low-trochospiral growth and rounded periphery. Ventral and dorsal sides highly convex. The umbo is pronounced with a massive plug. The diameter of the proloculus is around $100 \mu \mathrm{m}$. The diameter of the test with 2 whorls is around $0.75 \mathrm{~mm}$ and the length in section perpendicular to the coiling to axis is $0.50 \mathrm{~mm}$.

Age. The specimens identified here as Rotorbinella hensoni show the same size of the test and structural elements as $R$. hensoni described and illustrated by Hottinger (2014) in the Paleocene (SBZ2-SBZ3) and Rotorbinella sp. by Romero (2001) in the Bartonian-Priabonian from the Igualada Basin (Spain). In the section studied, this species occurs in the middle Lutetian 2 or SBZ 15 (samples G 54; Fig.3) and in the upper Lutetian or SBZ 16 (samples G 64 and $\mathrm{G} \mathrm{71;} \mathrm{Fig.} \mathrm{3).} \mathrm{Thus,} \mathrm{its} \mathrm{biostratigraphic} \mathrm{range} \mathrm{extends}$ from the Palaeocene to the Bartonian-Priabonian.

\section{GENUS Rotalia LAMARCK, 1804}

Type species: Rotalites trochidiformis LAMARCK, 1804

\section{Rotalia trochidiformis (LAMARCK, 1804)}

Fig. 26A-G

1954 Rotalia trochidiformis (LAMARCK). Smout, p. 43, pl. 1, figs. 1-6.

1963 Rotalia trochidiformis (LAMARCK). Reiss, p. 91, pl. 4, fig. 11; pl. 5, figs. 3, 18.

1980 Rotalia trochidiformis LAMARCK. Müller-Merz, p. 34, text-figs, 16-17, pl. 2, figs. 1-4; pl. 9, figs. 1-4; pl. 15, fig. 3 .

2014 Rotalia trochidiformis (LAMARCK, 1804). Hottinger, p. 35; pl. 3.4, figs. 1-4.

Material. This species is frequent in the following sections: Gabardiella, Isuela, Sierra Caballera, La Foz de Escalete, La Peña, Murillo and La Osqueta (Figs. 3-8; 11).

Description. Test with trochospiral growth and lenticularsubconical morphology. The dorsal side is smooth, and the ventral side is flattened or slightly convex. The ventral side shows the umbilical piles distributed from the umbo to the periphery of the shell. The length in longitudinal section is $0.9-1.8 \mathrm{~mm}$ and in section perpendicular to the coiling axis is $0.8-1.0 \mathrm{~mm}$ for $4-5$ whorls. The diameter of the proloculus is around $120 \mu \mathrm{m}$.
Age. According to Hottinger (2014) the biostratigraphic range of this species is Lutetian (SBZ13-SBZ16). In the material studied the SBZ13 is characterized by the intercalation of beds with this species (Figs. 3; 4; 5) and samples with Alveolina obtusa, A. callosa and $A$. stipes (A. stipes Zone) and samples with Assilina spira abrardi and Nummulites lehneri (A. spira abrardi and N. laevigatus-N. obesus Zones) indicating early Lutetian. The record of the SBZ14 is characterized by the intercalation of $R$. trochidiformis with beds bearing $N$. aspermontis and $N$. beneharnensis (Fig. 4), which indicates middle Lutetian 1 (N. gratus-N. beneharnensis Zone). The SBZ 15 is characterized by the association of $R$. trochidiformis with $N$. crassus and $N$. aff. deshayesi (samples E 16, P 17, M 1 and M 2; Figs. 6; 7;8), indicating middle Lutetian 2 (N. sordensis-N. crassus Zone). Finally, the SBZ16 is characterized by its association with $N$. deshayesi (samples I 54 and $\mathrm{P}$ 31; Figs. 4; 7), indicating late Lutetian (N. herbi-N. aturicus Zone).

GENUS Medocia PARVATI, 1971

Type species. Medocia blayensis PARVATI, 1971

Medocia blayensis PARVATI, 1971

Fig. 26H-O

1978 Medocia blayensis Parvati. Le Calvez and Blondeau, p. 28; pl. 1, figs. 1-2

2007 Medocia blayensis Parvati, 1971. Hottinger, p. 15; Pl. 12, figs. 1-9; pl.13, figs. 1-10

2014 Medocia blayensis Parvati, 1971. Hottinger, p. 35-37; figs. 3.8A-I and 3.9A-F

2016 Medocia blayensis Parvati, 1971. Serra-Kiel et al., p. 60-62; fig. 44

Material. This species is present in the Gabardiella, Isuela and Sierra Caballera sections (Figs. 3-5).

Description. Test with trochospiral growth and lenticular-subconical morphology. The dorsal side is smooth. The ventral side is convex-flattened and shows an umbo composed of tight piles. The wall is perforated by fine and well-marked pores. The funnels in longitudinal section are continuous (Fig. 26I). The diameter of the proloculus is around $120 \mu \mathrm{m}$ (Fig. 26K).

Age. According Hottinger $(2007,2014)$ and Serra-Kiel et al. (2016) the biostratigraphic range of this species is early?-middle Lutetian to Priabonian (SBZ13? -SBZ20). In the samples studied this species is associated with Alveolina stipes (sample I 2; Fig. 4), wich are between samples of A. callosa (Fig. 5), indicating early Lutetian (A. stipes Zone) or SBZ13. On the other hand, the association of $M$. blayensis with A. munieri (samples G 24 and G 35; Fig. 3) indicates middle Lutetian 1 (A. munieri Zone) or SBZ14. Finally, the presence of this species in SBZ15 is justified by 